Article

\title{
Synthesis, Optimization, Antifungal Activity, Selectivity, and CYP51 Binding of New 2-Aryl-3-azolyl-1-indolyl-propan-2-ols
}

\author{
Nicolas Lebouvier ${ }^{1,2}{ }^{(D}$, Fabrice Pagniez ${ }^{3}(\mathbb{D})$, Young Min Na ${ }^{1}$, Da Shi ${ }^{4}$, Patricia Pinson ${ }^{1}$, \\ Mathieu Marchivie ${ }^{5}{ }^{(D}$, Jean Guillon ${ }^{6}{ }^{D}$, Tarek Hakki ${ }^{7}$, Rita Bernhardt ${ }^{7}$ (D), Sook Wah Yee ${ }^{8}$, \\ Claire Simons ${ }^{8}\left(\mathbb{D}\right.$, Marie-Pierre Lézé ${ }^{1,9}$, Rolf W. Hartmann ${ }^{9}\left(\mathbb{D}\right.$, Angélique Mularoni ${ }^{10}(\mathbb{D}$, \\ Guillaume Le Baut ${ }^{1}$, Isabelle Krimm ${ }^{11,12} \mathbb{D}$, Ruben Abagyan ${ }^{4} \mathbb{D}$, Patrice Le Pape ${ }^{3, *(D)}$ and \\ Marc Le Borgne ${ }^{1,10, *(D)}$
}

1 EA1155-IICiMed, Institut de Recherche en Santé 2, Département de Pharmacochimie, Nantes Atlantique Universités, Université de Nantes, F-44200 Nantes, France; nicolas.lebouvier@univ-nc.nc (N.L.); ymna@joowonpat.com (Y.M.N.); patricia.pinson@univ-nantes.fr (P.P.); mpl_leze@yahoo.fr (M.-P.L.); guillaume.lebaut@wanadoo.fr (G.L.B.)

2 Institut des Sciences Exactes et Appliquées (ISEA) EA 7484, Université de la Nouvelle-Calédonie, 98851 Noumea CEDEX, New Caledonia

3 EA1155-IICiMed, Institut de Recherche en Santé 2, Département de Parasitologie et Mycologie Médicale, Nantes Atlantique Universités, Université de Nantes, F-44200 Nantes, France; fabrice.pagniez@univ-nantes.fr

4 Skaggs School of Pharmacy and Pharmaceutical Sciences, University of California, San Diego, CA 92093, USA; das046@ucsd.edu (D.S.); ruben@ucsd.edu (R.A.)

5 ICMCB CNRS-UPR 9048, Université de Bordeaux, F-33608 Pessac CEDEX, France; mathieu.marchivie@icmcb.cnrs.fr

6 ARNA Laboratory, INSERM U1212, UMR CNRS 5320, UFR des Sciences Pharmaceutiques, Université de Bordeaux, F-33076 Bordeaux, France; jean.guillon@u-bordeaux.fr

7 Department of Biochemistry, Saarland University, Campus B2.2, 66123 Saarbrücken, Germany; t.hakki@dr-hakki.de (T.H.); ritabern@mx.uni-saarland.de (R.B.)

8 School of Pharmacy \& Pharmaceutical Sciences, Cardiff University, King Edward VII Avenue, Cardiff CF10 3NB, UK; sookwah.yee@ucsf.edu (S.W.Y.); SimonsC@cardiff.ac.uk (C.S.)

9 Department of Pharmacy, Pharmaceutical and Medicinal Chemistry, Saarland University, Campus E8.1, 66123 Saarbrücken, Germany; Rolf.Hartmann@helmholtz-hzi.de

10 EA 4446 Bioactive Molecules and Medicinal Chemistry, Faculté de Pharmacie-ISPB, SFR Santé Lyon-Est CNRS UMS3453-INSERM US7, Université Claude Bernard Lyon 1, Université de Lyon, CEDEX 8, F-69373 Lyon, France; angelique.mularoni@univ-lyon1.fr

11 Centre de RMN à Très Hauts Champs, CNRS, ENS, Université Claude Bernard Lyon 1, Université de Lyon, 5 rue de la Doua, F-69100 Villeurbanne, France; isabelle.krimm@univ-lyon1.fr

12 Centre de Recherche en Cancérologie de Lyon, INSERM 1052, CNRS 5286, Centre Léon Bérard, Université Claude Bernard Lyon 1, Université de Lyon, F-69008 Lyon, France

* Correspondence: Patrice.Le-Pape@univ-nantes.fr (P.L.P.); marc.le-borgne@univ-lyon1.fr (M.L.B.); Tel.: +33-240-084-072 (P.L.P.); +33-478-777-082 (M.L.B.)

Received: 15 July 2020; Accepted: 5 August 2020; Published: 8 August 2020

check for updates

\begin{abstract}
A series of 2-aryl-3-azolyl-1-indolyl-propan-2-ols was designed as new analogs of fluconazole (FLC) by replacing one of its two triazole moieties by an indole scaffold. Two different chemical approaches were then developed. The first one, in seven steps, involved the synthesis of the key intermediate 1-(1H-benzotriazol-1-yl)methyl- $1 H$-indole and the final opening of oxiranes by imidazole or $1 H$-1,2,4-triazole. The second route allowed access to the target compounds in only three steps, this time with the ring opening by indole and analogs. Twenty azole derivatives were tested against Candida albicans and other Candida species. The enantiomers of the best anti-Candida compound, 2-(2,4-dichlorophenyl)-3-(1H-indol-1-yl)-1-(1H-1,2,4-triazol-1-yl)-propan-2-ol (8g), were analyzed
\end{abstract}


by $\mathrm{X}$-ray diffraction to determine their absolute configuration. The (-)-8g enantiomer (Minimum inhibitory concentration (MIC) $=\mathrm{IC}_{80}=0.000256 \mu \mathrm{g} / \mathrm{mL}$ on C. albicans CA98001) was found with the $S$-absolute configuration. In contrast the (+)-8g enantiomer was found with the $R$-absolute configuration (MIC $=0.023 \mu \mathrm{g} / \mathrm{mL}$ on C. albicans CA98001). By comparison, the MIC value for FLC was determined as $0.020 \mu \mathrm{g} / \mathrm{mL}$ for the same clinical isolate. Additionally, molecular docking calculations and molecular dynamics simulations were carried out using a crystal structure of Candida albicans lanosterol $14 \alpha$-demethylase (CaCYP51). The (-)-(S)-8g enantiomer aligned with the positioning of posaconazole within both the heme and access channel binding sites, which was consistent with its biological results. All target compounds have been also studied against human fetal lung fibroblast (MRC-5) cells. Finally, the selectivity of four compounds on a panel of human P450-dependent enzymes (CYP19, CYP17, CYP26A1, CYP11B1, and CYP11B2) was investigated.

Keywords: azoles; antifungal agents; indole; microwave irradiation; X-ray crystallography; Candida species; docking; CYP51; selectivity; cytochromes P450

\section{Introduction}

Invasive fungal infections are related to a high mortality rate despite the availability of several antifungal drugs. Fungi species that belong to one of these four genera (Cryptococcus, Candida, Aspergillus, and Pneumocystis) kill about one and a half million people every year [1,2]. These infections have increased in frequency and severity over the last two decades as a result of an increasing number of immunocompromised hosts due to cancer chemotherapy, organ and bone marrow transplantation, human immunodeficiency virus, or therapy against autoimmune and inflammatory diseases especially with TNF inhibitors [3]. Candida albicans (C. albicans) is the major opportunistic pathogen of fungal infections and Candida spp. are the fourth most common nosocomial bloodstream pathogens in the USA with a mortality rate of $40 \%$ [1,2].

For many years, the polyene amphotericin B has been the only available antifungal drug for invasive fungal infections despite nephrotoxicity, infusion-related reactions, and other adverse effects [4]. To this day, approved antifungal agents belong to only four drug classes: Polyenes, azoles, echinocandins, and anti-metabolites [5]. Introduction of triazoles (e.g., fluconazole (FLC), itraconazole) offered new treatment options with excellent antifungal activity and a good safety profile. Prophylactic use of FLC has been developed to reduce the risk of Candida colonization and infection in high-risk patients with minimal toxicity [6,7]. Nevertheless, the emergence of $C$. krusei and C. glabrata infections in patients with bone marrow transplantation or neutropenia receiving FLC prophylaxis has been reported [8,9]. Development of Candida spp. resistance has also commonly been observed in HIV-infected patients who received prolonged FLC treatment for oropharyngeal candidiasis $[2,10,11]$.

Fourth generation azoles (e.g., voriconazole, posaconazole, ravuconazole, isavuconazole) and echinocandins (e.g., caspofungin, micafungin, anidulafungin) approved for use or under clinical trials have proven to be less toxic than conventional amphotericin $B$, resulting in a significant advance in treatment of serious fungal infections. However, voriconazole interferes with many drugs and its prolonged use may expose severely immunocompromised patients to the risk of zygomycosis [12], while echinocandins are not available orally [13]. Consequently, most patients requiring therapy for invasive candidiasis are still placed on the safe, inexpensive, and orally available fluconazole. Despite recent advances in antifungal chemotherapy, the mortality rates of invasive fungal infections have remained unchanged and there is a necessity for the development of new antifungal compounds. Aiming at new and effective antifungal drugs, our attention was focused on the azole derivatives because of their low toxicity, broad spectrum of activity, and favorable pharmacokinetic properties $[10,11,14]$.

Antifungal azoles (Figure 1) target the P450-dependent enzyme lanosterol $14 \alpha$-demethylase (CYP51), preventing the production of ergosterol, a key component in the fungal cell membrane [15]. 
Depletion of ergosterol and accumulation of $14 \alpha$-methylated sterols alter membrane fluidity, increase permeability, and reduce the activity of membrane-associated enzymes. Azoles bind to the iron of the protoporphyrin unit located in the active site of CYP51, preventing the access of the natural substrate lanosterol [16,17]. Azoles are also used for the treatment of estrogen-dependent disease by inhibition of aromatase (CYP19) in breast cancer therapy [18,19], and the inhibition of human P450-dependent enzymes is an unwanted side effect that could lead to impediments for safe therapeutic profile, including toxicity and undesirable drug interactions [20]. Selectivity of antifungal agents is therefore crucial because of the high levels of similarity between the eukaryotic fungal pathogens and the human hosts, and must be considered as a top priority in the development of new antifungal azoles $[5,10,21]$.

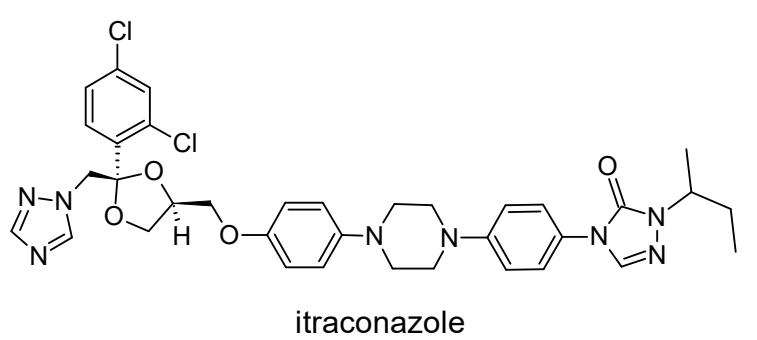<smiles>Fc1ccc(C(Cn2cncn2)(Cn2cncn2)Cn2cncn2)c(F)c1</smiles>

fluconazole

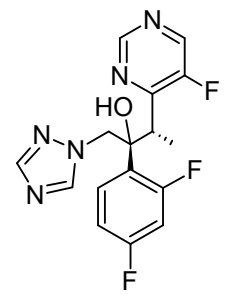

voriconazole<smiles>CC[C@@H](C(C)O)n1ncn(-c2ccc(N3CCN(c4ccc(OCC5CC[C@@](Cn6cncn6)(c6ccc(F)cc6F)O5)cc4)CC3)cc2)c1=O</smiles><smiles>CCCCOc1ccc(F)c(C(O)(Cn2cncn2)C(F)c2ncc(-c3ccc(C#N)cc3)s2)c1</smiles>

Figure 1. Structures of the main azole antifungal agents.

Our research group has developed several potent series of antifungal compounds based on an indole scaffold with better in vitro antifungal activities against C. albicans compared with FLC [22-27]. To continue this pharmacomodulation strategy, we describe in the present paper the synthesis of 2-phenyl-1-(1H-indol-1-yl)-3-(azolyl)propan-2-ols using two different synthetic routes and their anti-Candida activities. The safety profile of target compounds was also evaluated by a cytotoxicity assay on human fetal lung fibroblast (MRC-5) cells, and by selectivity assessment using a panel of human P450-dependent enzymes. Additionally, separation of the two enantiomers of the most potent compound, 2-(2,4-dichlorophenyl)-3-(1H-indol-1-yl)-1-(1H-1,2,4-triazol-1-yl)-propan-2-ol 8g, was performed and the determination of their absolute configuration was achieved. A molecular modeling study was finally performed to assess the binding feasibility of $(R)-\mathbf{8 g}$ and $(S)-\mathbf{8 g}$ for lanosterol $14 \alpha$-demethylase (CYP51).

\section{Results and Discussion}

\subsection{Chemistry}

Two synthetic routes were designed to obtain the 2-phenyl-3-(1H-indol-1-yl)-1-(azol-1-yl)propan-2-ol derivatives $8 \mathbf{a}-\mathbf{g}$ and $\mathbf{1 1 a}-\mathbf{1}$.

The first pathway strategy (route 1) involved the synthesis of the key intermediate 1-(1H-benzotriazol-1-yl)methyl-1H-indole 4 (Scheme 1). According to this scheme, hydroxymethylation of 
benzotriazole 1 using an aqueous solution of formaldehyde quickly gave 1-hydroxymethyl-1H-benzotriazole 2, which was converted into 1 -chloromethyl- $1 H$-benzotriazole 3 using thionyl chloride at $0{ }^{\circ} \mathrm{C}$. The indole was then alkylated by compound 3 in the presence of sodium hydride $(\mathrm{NaH})$ in dimethyl sulfoxide (DMSO) to give the intermediate 4 . Lithiation of 4 with $n$-butyllithium at $-78{ }^{\circ} \mathrm{C}$ in tetrahydrofuran (THF) followed by addition of the appropriate esters gave the target $\alpha$-benzotriazolyl ketones $5 \mathbf{a}-\mathbf{f}$. Debenzotriazolylation of $5 \mathbf{a}-\mathbf{f}$ occurred in the presence of zinc and acetic acid in a mixture of THF/EtOH $(1: 1, v / v)$ under ultrasonic activation. The corresponding ketones $\mathbf{6 a}-\mathbf{f}$ were then converted into oxiranes $7 \mathbf{a}-\mathbf{f}$ by the Corey-Chaykovsky epoxidation using trimethylsulfoxonium iodide (TMSOI) and an aqueous solution of sodium hydroxide in dichloromethane under reflux. The ring opening of $\mathbf{7 a - f}$ with $1 H$-1,2,4-triazole or imidazole in the presence of potassium carbonate $\left(\mathrm{K}_{2} \mathrm{CO}_{3}\right)$ at reflux in acetonitrile $\left(\mathrm{CH}_{3} \mathrm{CN}\right)$ gave the target 2-aryl-3-(1H-indol-1-yl)-1-(azol-1-yl)propan-2-ol derivatives $\mathbf{8 a - g}$.<smiles></smiles>

1

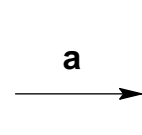<smiles>OCn1nnc2ccccc21</smiles>

2

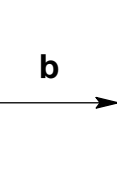<smiles>ClCn1nnc2ccccc21</smiles>

3<smiles>c1ccc2c(c1)ccn2Cn1nnc2ccccc21</smiles>

d

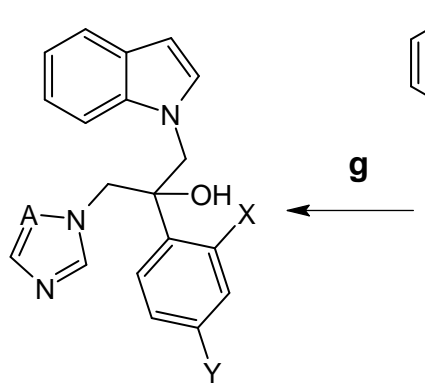

8a: $X=H, Y=F, A=C H$

8b: $X=\mathrm{H}, Y=\mathrm{Cl}, \mathrm{A}=\mathrm{CH}$

8c: $X=H, Y=B r, A=C H$

8d: $X=F, Y=F, A=C H$

8e: $X=\mathrm{Cl}, Y=\mathrm{Cl}, \mathrm{A}=\mathrm{CH}$

8f: $X=H, Y=C_{3}, A=N$

8g: $X=C l, Y=C l, A=N$

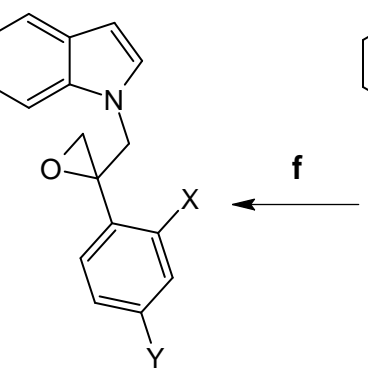

7a-f

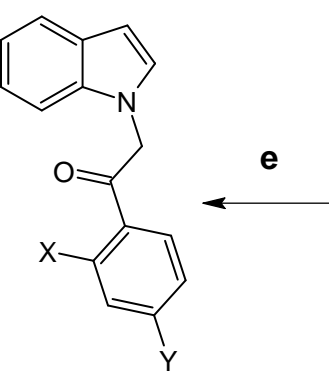

6a-f<smiles>[X]c1ccc(C(=O)C(n2ccc3ccccc32)n2nnc3ccccc32)c([X])c1</smiles>

5a-f

5a, 6a, 7a: $X=H, Y=F$

5b, 6b, 7b: $X=\mathrm{H}, Y=\mathrm{Cl}$

5c, 6c, 7c: $X=\mathrm{H}, Y=\mathrm{Br}$

5d, 6d, 7d: $X=\mathrm{H}, Y=\mathrm{CF}_{3}$

5e, 6e, 7e: $X=F, Y=F$

5f, 6f, 7f: $X=\mathrm{Cl}, Y=\mathrm{Cl}$

Scheme 1. Synthesis of compounds 8a-g (Route 1). Reagents and conditions: (a) $\mathrm{HCHO}_{\mathrm{aq}}$, room temperature (rt), 5 min; (b) $\mathrm{SOCl}_{2}$, reflux, 1 h; (c) NaH, $1 \mathrm{H}$-indole, DMSO, rt, 12 h; (d) n-BuLi, ethylbenzoate derivatives, THF, $-78{ }^{\circ} \mathrm{C}$ to rt, $12 \mathrm{~h}$; (e) $\mathrm{AcOH}, \mathrm{Zn}, \mathrm{THF}, \mathrm{EtOH}$, ultrasound, $35^{\circ} \mathrm{C}, 5 \mathrm{~h}$; (f) $\mathrm{TMSOI}, \mathrm{NaOH}_{\mathrm{aq}}$, $\mathrm{CH}_{2} \mathrm{Cl}_{2}$, reflux, $48 \mathrm{~h}$; (g) $\mathrm{K}_{2} \mathrm{CO}_{3}$, imidazole or $1 \mathrm{H}-1,2,4$-triazole, $\mathrm{CH}_{3} \mathrm{CN}$, reflux, $7 \mathrm{~h}$.

In order to reduce the number of reaction steps, we investigated another synthetic pathway called route 2 (Scheme 2). First, imidazole and $1 \mathrm{H}$-1,2,4-triazole were alkylated by commercially available halogenoacetophenones using $\mathrm{K}_{2} \mathrm{CO}_{3}$ in $\mathrm{CH}_{3} \mathrm{CN}$ under microwave heating $\left(85^{\circ} \mathrm{C}, 50 \mathrm{~W}\right)$ to give the target ketones $\mathbf{9 a}-\mathbf{f}$, which were converted to oxiranes $\mathbf{1 0 a}-\mathbf{f}$ in the presence of TMSOI and an aqueous solution of sodium hydroxide in toluene under microwave heating $\left(80^{\circ} \mathrm{C}, 50 \mathrm{~W}\right)$. The reaction times of 
these two steps (alkylation and epoxidation) are greatly reduced by using microwave heating as we have already reported [27]. Finally, the ring opening of 10a-f with indole using NaH in DMSO gave the derivatives $8 \mathrm{~g}$ and $\mathbf{1 1 a}-\mathbf{e}$. A similar ring opening of the intermediates $\mathbf{9 d}$ and $\mathbf{9 e}$ by indoles with methyl groups in position 2 and/or 3 furnished the target derivatives 11f-k. In the case of the synthesis of compound $8 \mathrm{~g}$, route 2 gave a great improvement of the overall yield (route 1: $5 \%$ vs. route 2: $29 \%$ ).

$$
\begin{array}{ll}
X=H, Y=F, Z=C l & \text { 9a, 10a: } X=H, Y=F, A=N \\
X=H, Y=C l, Z=C l & \text { 9b, 10b: } X=H, Y=C l, A=N \\
X=H, Y=B r, Z=C l & \text { 9c, 10c: } X=H, Y=B r, A=N \\
X=F, Y=F, Z=C l & \text { 9d, 10d: } X=F, Y=F, A=N \\
X=C l, Y=C l, Z=C l & \text { 9e, 10e: } X=C l, Y=C l, A=N \\
X=H, Y=C F_{3}, Z=B r & \text { 9f, 10f: } X=H, Y=C F_{3}, A=C H
\end{array}
$$

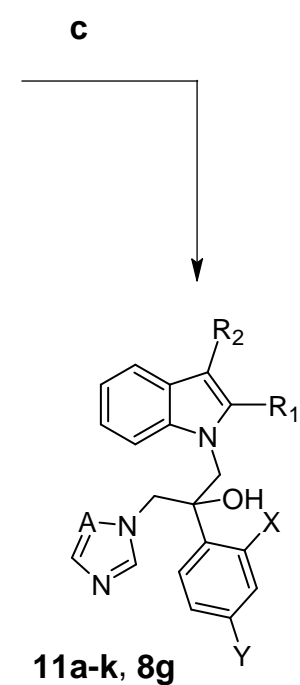

$$
\begin{aligned}
& \text { 11a: } X=H, Y=F, A=N, R_{1}=H, R_{2}=H \\
& \text { 11b: } X=H, Y=C l, A=N, R_{1}=H, R_{2}=H \\
& \text { 11c: } X=H, Y=B r, A=N, R_{1}=H, R_{2}=H \\
& \text { 11d: } X=F, Y=F, A=N, R_{1}=H, R_{2}=H \\
& \text { 8g: } X=C l, Y=C l, A=N, R_{1}=H, R_{2}=H \\
& \text { 11e: } X=H, Y=C F=A=C H, R_{1}=H, R_{2}=H \\
& \text { 11f: } X=F, Y=F, A=N, R_{1}=M e, R_{2}=H \\
& \text { 11g: } X=C l, Y=C l, A=N, R_{1}=M e, R_{2}=H \\
& \text { 11h: } X=F, Y=F, A=N, R_{1}=H, R_{2}=M e \\
& \text { 11i: } X=C l, Y=C l, A=N, R_{1}=H, R_{2}=M e \\
& \text { 11j: } X=F, Y=F, A=N, R_{1}=M e, R_{2}=M e \\
& \text { 11k: } X=C l, Y=C l, A=N, R_{1}=M e, R_{2}=M e
\end{aligned}
$$

Scheme 2. Synthesis of compounds $8 \mathrm{~g}$ and 11a-k (Route 2). Reagents and conditions: (a) $\mathrm{K}_{2} \mathrm{CO}_{3}$, imidazole or $1 \mathrm{H}-1,2,4$-triazole, $\mathrm{CH}_{3} \mathrm{CN}$, MW $85^{\circ} \mathrm{C}, 50 \mathrm{~W}, 50 \mathrm{~min}$; (b) $\mathrm{NaOH}_{\mathrm{aq}} 20 \%$, TMSOI, $\mathrm{CH}_{2} \mathrm{Cl}_{2}$, reflux, $72 \mathrm{~h} ;$ (c) $\mathrm{NaH}$, indole derivative, DMSO, rt, $12 \mathrm{~h}$.

To observe the influence of the nitrogen atom position in the azole ring, the effective route 2 was used to synthesize two other 2-(2,4-dichlorophenyl)-3-(1H-indol-1-yl)-1-(azol-1-yl)propan-2-ol derivatives 111 and $11 \mathrm{~m}$ with azole rings $1 \mathrm{H}-1,2,3$-triazole and $2 \mathrm{H}-1,2,3$-triazole (Scheme 3). Alkylation of $1 \mathrm{H}-1,2,3$-triazole by $2,2^{\prime}, 4^{\prime}$-trichloroacetophenone gave a mixture of $\mathrm{N}-1 \mathbf{9 g}$ and $\mathrm{N}-2 \mathbf{9 h}$ alkylation products. This alkylation by conventional heating provided a ratio of $61 / 39 \mathrm{~N}-1$ and $\mathrm{N}-2$ products while a microwave activation at the same temperature gave a 49/51 mixture. Epoxidation and indole 
alkylation from $9 \mathrm{~g}$ and $9 \mathrm{~h}$ under the same conditions as in route 2 gave the final products 111 and $11 \mathrm{~m}$ (Scheme 3).<smiles>CC(C)(C)C1(c2ccc(Cl)cc2Cl)CO1</smiles>
condition b: $61 / 39$
9g: $\mathrm{A}=\mathrm{N}, \mathrm{B}=\mathrm{CH}$
10g: $A=N, B=C H$
11I: $A=N, B=C H$
9h: $\mathrm{A}=\mathrm{CH}, \mathrm{B}=\mathrm{N}$
10h: $\mathrm{A}=\mathrm{CH}, \mathrm{B}=\mathrm{N}$
11m: $\mathrm{A}=\mathrm{CH}, \mathrm{B}=\mathrm{N}$

Scheme 3. Synthesis of compounds 111 and $11 \mathrm{~m}$. Reagents and conditions: (a) $\mathrm{K}_{2} \mathrm{CO}_{3}, 1 \mathrm{H}-1,2,3$-triazole, $\mathrm{CH}_{3} \mathrm{CN}$, MW $85^{\circ} \mathrm{C}, 50 \mathrm{~W}, 50 \mathrm{~min}$; (b) $\mathrm{K}_{2} \mathrm{CO}_{3}, 1 \mathrm{H}$-1,2,3-triazole, $\mathrm{CH}_{3} \mathrm{CN}, 85^{\circ} \mathrm{C}, 8 \mathrm{~h}$; (c) $\mathrm{NaOH}_{\mathrm{aq}} 20 \%$, TMSOI, $\mathrm{CH}_{2} \mathrm{Cl}_{2}$, reflux, $72 \mathrm{~h}$; (d) $\mathrm{NaH}$, indole, DMSO, rt, $12 \mathrm{~h}$.

\subsection{X-ray Structural Studies}

In order to confirm the absolute configuration of the synthesized compounds $8 \mathrm{~g}, \mathrm{X}$-ray structure analyses for the two derivatives were performed. The atom labeling and thermal ellipsoids of $(+)-8 \mathrm{~g}$ and (-)-8g are shown in Figures 2 and 3. Two independent molecules, designated as A and B, were found in the asymmetric crystallographic unit of (+)-8g and (-)-8g. The configuration of $(+)-8 \mathrm{~g}$ and $(-)-8 \mathbf{g}$ was determined by observing and calculating the $F(+) / F(-)$ ratios of Bijvoet pairs with the mean $F$ value of each independent reflection. Based on the results, the absolute configuration at C-9 and C-59 in (+)-8g was determined to be $R$. The (-)-8g enantiomer was found with the $S$-absolute configuration.

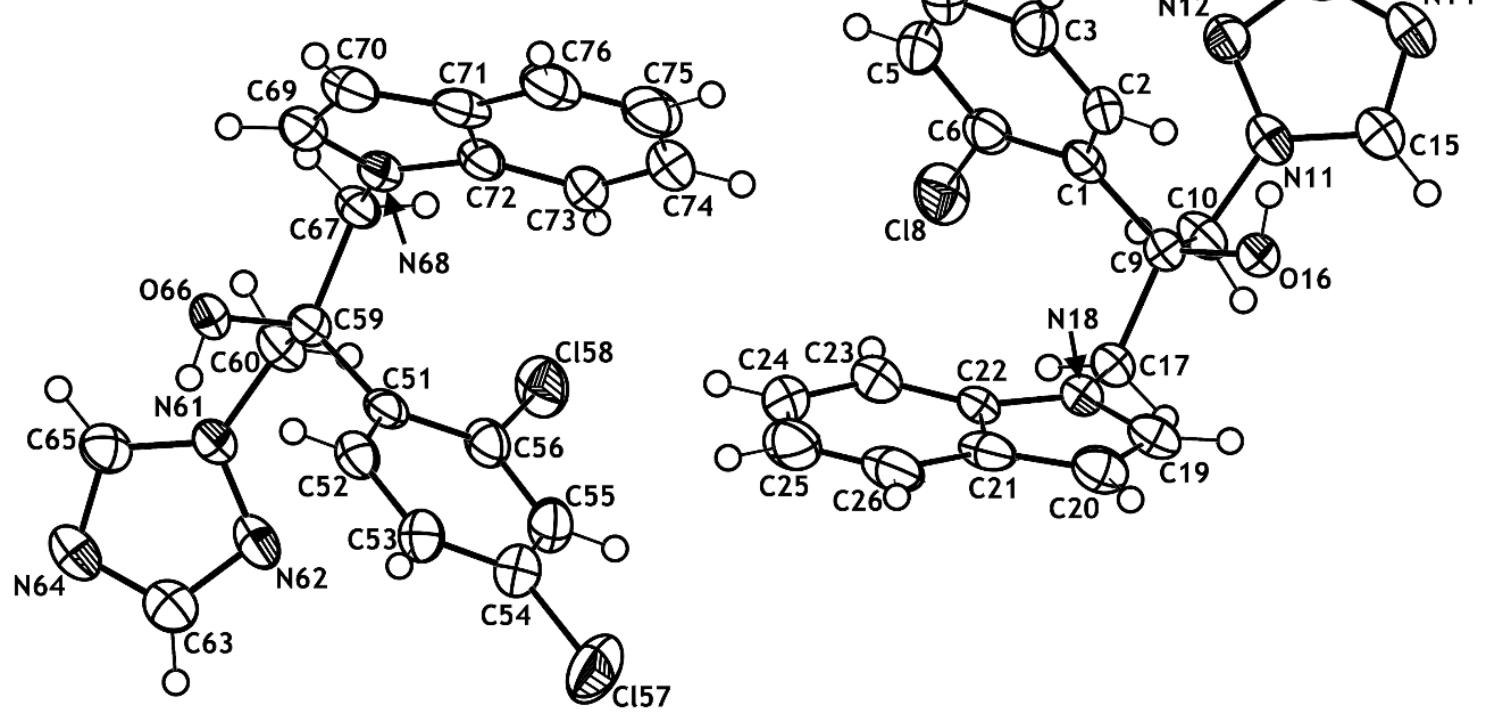

Figure 2. View of the crystal structure of $(R)-8 \mathrm{~g}$ with our numbering scheme, displacement ellipsoids are drawn at the $30 \%$ probability level. 


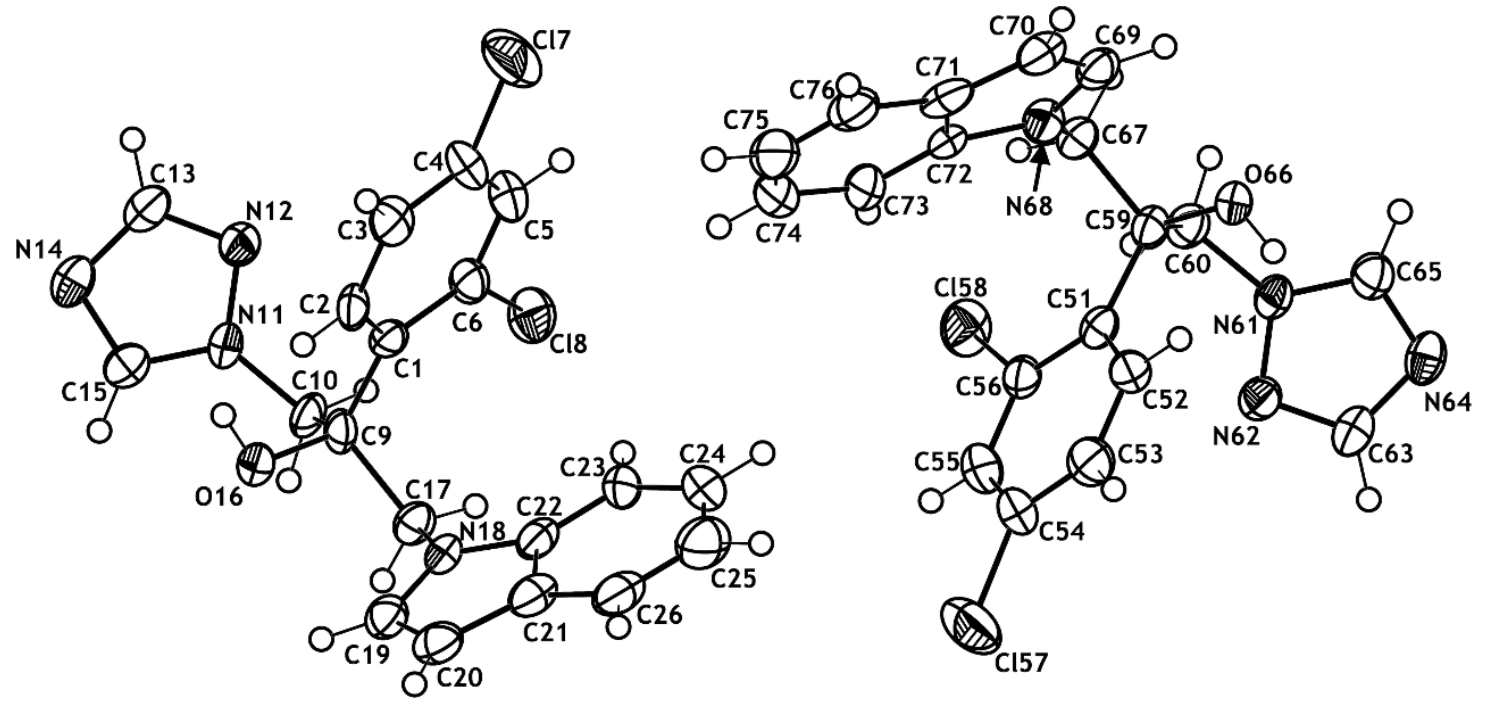

Figure 3. View of the crystal structure of (S)-8g with our numbering scheme, displacement ellipsoids are drawn at the $30 \%$ probability level.

\subsection{Biological Results}

\subsubsection{In Vitro Anti-Candida Activity}

All anti-Candida activities of propanol derivatives $\mathbf{8 a} \mathbf{a}-\mathbf{g}$ and $\mathbf{1 1 a}-\mathbf{m}$ are presented in Table 1. Concerning the expression of the results during the evaluation of the compounds, we deliberately chose to calculate a more selective minimal inhibitory concentration $\left(\mathrm{MIC}=\mathrm{IC}_{80}, \mu \mathrm{g} / \mathrm{mL}\right)$ than an $\mathrm{IC}_{50}$ in order to highlight some very active compounds. Concerning the $1 H$-1,2,4-triazole sub-series, substitutions of the phenyl ring by halogens greatly impacted anti-C. albicans activities. The 4-trifluoromethylated $8 \mathbf{8}$, 4-chlorinated 11b, 4-brominated 11c, and 2,4-difluorinated 11d compounds had activities comparable with FLC (MIC $=0.020 \mu \mathrm{g} / \mathrm{mL}$ on C. albicans CA98001), while the 4-fluorinated derivative 11a was less active (MIC $=0.210 \mu \mathrm{g} / \mathrm{mL}$ ). The most favorable substitution corresponded to the 2,4-dichlorinated phenyl ring for compound $\mathbf{8 g}$. The asymmetric carbon of the propanol chain also played a very important role in the activity against $C$. albicans. Indeed, activity of the $(+)-(R)$-enantiomer was similar to FLC (MIC $=0.023 \mu \mathrm{g} / \mathrm{mL}$ ), whereas the $(-)-(S)$-enantiomer had an action comparable with the racemic mixture (MIC values of 0.000256 and $0.000259 \mu \mathrm{g} / \mathrm{mL}$, respectively).

In the imidazole sub-series, there was little difference in activity depending on the substitution of the phenyl ring because all compounds had activities similar to that of FLC except for the 2,4-difluorinated derivative $8 \mathbf{d}$, which was 57 times more active $(\mathrm{MIC}=0.00035 \mu \mathrm{g} / \mathrm{mL}$ ). There was no correlation between the imidazole and $1 \mathrm{H}-1,2,4$-triazole series according to the substitution of the phenyl ring. Compounds of $1 H$-1,2,3-triazole and $2 H$-1,2,3-triazole series with 2,4-dichlophenyl substitution 111-m were totally inactive. This pharmacomodulation of the azolyl unit highlighted the necessity of the $1 H-1,2,4$-triazole or imidazole moiety to promote activity against $C$. albicans. The inactivity of $1 H-1,2,3$-triazole and $2 H-1,2,3$-triazole derivatives could be explained by the impossibility of these rings to coordinate with the iron atom of CYP51. 
Table 1. Anti-Candida activity of propanol derivatives $\mathbf{8 a - g}$ and 11a-m.

\begin{tabular}{|c|c|c|c|c|c|c|c|c|c|}
\hline Compound & A & B & $\mathrm{C}$ & D & $\mathbf{R}_{1}$ & $\mathbf{R}_{2}$ & $X$ & $\mathbf{Y}$ & $\begin{array}{l}\mathrm{MIC}^{1}(\mu \mathrm{g} / \mathrm{mL}) \mathrm{C} . \\
\text { albicans CA98001 }\end{array}$ \\
\hline $8 \mathbf{a}$ & $\mathrm{CH}$ & $\mathrm{CH}$ & $\mathrm{N}$ & $\mathrm{CH}$ & $\mathrm{H}$ & $\mathrm{H}$ & $\mathrm{H}$ & F & 0.03 \\
\hline $8 b$ & $\mathrm{CH}$ & $\mathrm{CH}$ & $\mathrm{N}$ & $\mathrm{CH}$ & $\mathrm{H}$ & $\mathrm{H}$ & $\mathrm{H}$ & $\mathrm{Cl}$ & 0.02 \\
\hline $8 c$ & $\mathrm{CH}$ & $\mathrm{CH}$ & $\mathrm{N}$ & $\mathrm{CH}$ & $\mathrm{H}$ & $\mathrm{H}$ & $\mathrm{H}$ & $\mathrm{Br}$ & 0.02 \\
\hline $8 d$ & $\mathrm{CH}$ & $\mathrm{CH}$ & $\mathrm{N}$ & $\mathrm{CH}$ & $\mathrm{H}$ & $\mathrm{H}$ & $\mathrm{F}$ & $\mathrm{F}$ & 0.00035 \\
\hline $8 e$ & $\mathrm{CH}$ & $\mathrm{CH}$ & $\mathrm{N}$ & $\mathrm{CH}$ & $\mathrm{H}$ & $\mathrm{H}$ & $\mathrm{Cl}$ & $\mathrm{Cl}$ & 0.062 \\
\hline $11 \mathrm{e}$ & $\mathrm{CH}$ & $\mathrm{CH}$ & $\mathrm{N}$ & $\mathrm{CH}$ & $\mathrm{H}$ & $\mathrm{H}$ & $\mathrm{H}$ & $\mathrm{CF}_{3}$ & 0.23 \\
\hline $11 a$ & $\mathrm{~N}$ & $\mathrm{CH}$ & $\mathrm{N}$ & $\mathrm{CH}$ & $\mathrm{H}$ & $\mathrm{H}$ & $\mathrm{H}$ & $\mathrm{F}$ & 0.21 \\
\hline $11 b$ & $\mathrm{~N}$ & $\mathrm{CH}$ & $\mathrm{N}$ & $\mathrm{CH}$ & $\mathrm{H}$ & $\mathrm{H}$ & $\mathrm{H}$ & $\mathrm{Cl}$ & 0.024 \\
\hline 11c & $\mathrm{N}$ & $\mathrm{CH}$ & $\mathrm{N}$ & $\mathrm{CH}$ & $\mathrm{H}$ & $\mathrm{H}$ & $\mathrm{H}$ & $\mathrm{Br}$ & 0.027 \\
\hline 11d & $\mathrm{N}$ & $\mathrm{CH}$ & $\mathrm{N}$ & $\mathrm{CH}$ & $\mathrm{H}$ & $\mathrm{H}$ & $\mathrm{F}$ & $\mathrm{F}$ & 0.0198 \\
\hline $8 g$ & $\mathrm{~N}$ & $\mathrm{CH}$ & $\mathrm{N}$ & $\mathrm{CH}$ & $\mathrm{H}$ & $\mathrm{H}$ & $\mathrm{Cl}$ & $\mathrm{Cl}$ & 0.000259 \\
\hline$(+)-(R)-8 \mathrm{~g}$ & $\mathrm{~N}$ & $\mathrm{CH}$ & $\mathrm{N}$ & $\mathrm{CH}$ & $\mathrm{H}$ & $\mathrm{H}$ & $\mathrm{Cl}$ & $\mathrm{Cl}$ & 0.023 \\
\hline$(-)-(S)-8 \mathrm{~g}$ & $\mathrm{~N}$ & $\mathrm{CH}$ & $\mathrm{N}$ & $\mathrm{CH}$ & $\mathrm{H}$ & $\mathrm{H}$ & $\mathrm{Cl}$ & $\mathrm{Cl}$ & 0.000256 \\
\hline $8 f$ & $\mathrm{~N}$ & $\mathrm{CH}$ & $\mathrm{N}$ & $\mathrm{CH}$ & $\mathrm{H}$ & $\mathrm{H}$ & $\mathrm{H}$ & $\mathrm{CF}_{3}$ & 0.009 \\
\hline $11 \mathrm{f}$ & $\mathrm{N}$ & $\mathrm{CH}$ & $\mathrm{N}$ & $\mathrm{CH}$ & $\mathrm{CH}_{3}$ & $\mathrm{H}$ & $\mathrm{F}$ & $\mathrm{F}$ & 0.022 \\
\hline $11 \mathrm{~g}$ & $\mathrm{~N}$ & $\mathrm{CH}$ & $\mathrm{N}$ & $\mathrm{CH}$ & $\mathrm{CH}_{3}$ & $\mathrm{H}$ & $\mathrm{Cl}$ & $\mathrm{Cl}$ & 0.0058 \\
\hline $11 \mathrm{~h}$ & $\mathrm{~N}$ & $\mathrm{CH}$ & $\mathrm{N}$ & $\mathrm{CH}$ & $\mathrm{H}$ & $\mathrm{CH}_{3}$ & $\mathrm{~F}$ & $\mathrm{Cl}$ & 0.0011 \\
\hline $11 \mathrm{i}$ & $\mathrm{N}$ & $\mathrm{CH}$ & $\mathrm{N}$ & $\mathrm{CH}$ & $\mathrm{H}$ & $\mathrm{CH}_{3}$ & $\mathrm{Cl}$ & $\mathrm{Cl}$ & 0.007 \\
\hline $11 \mathrm{j}$ & $\mathrm{N}$ & $\mathrm{CH}$ & $\mathrm{N}$ & $\mathrm{CH}$ & $\mathrm{CH}_{3}$ & $\mathrm{CH}_{3}$ & $\mathrm{~F}$ & $\mathrm{~F}$ & 0.157 \\
\hline $11 \mathrm{k}$ & $\mathrm{N}$ & $\mathrm{CH}$ & $\mathrm{N}$ & $\mathrm{CH}$ & $\mathrm{CH}_{3}$ & $\mathrm{CH}_{3}$ & $\mathrm{Cl}$ & $\mathrm{Cl}$ & 1.246 \\
\hline 111 & $\mathrm{~N}$ & $\mathrm{~N}$ & $\mathrm{CH}$ & $\mathrm{CH}$ & $\mathrm{H}$ & $\mathrm{H}$ & $\mathrm{Cl}$ & $\mathrm{Cl}$ & $>100$ \\
\hline $11 \mathrm{~m}$ & $\mathrm{~N}$ & $\mathrm{CH}$ & $\mathrm{CH}$ & $\mathrm{N}$ & $\mathrm{H}$ & $\mathrm{H}$ & $\mathrm{Cl}$ & $\mathrm{Cl}$ & $>100$ \\
\hline KTC & & & & & & & & & 0.005 \\
\hline FLC & & & & & & & & & 0.02 \\
\hline
\end{tabular}

${ }^{1}$ Minimum inhibitory concentration ( $\mathrm{MIC}=\mathrm{IC}_{80}, \mu \mathrm{g} / \mathrm{mL}$ ) was expressed as the mean of triplicate measures.

The last work of pharmacomodulation focused on the presence of the methyl group in position 2 and/or 3 of the indole ring. With a 2,4-difluorinated phenyl group, the presence of a methyl at position 2 on the indole ring did not change the activity $(\mathbf{1 1 f}, \mathrm{MIC}=0.022 \mu \mathrm{g} / \mathrm{mL})$; on the other hand, the introduction of a methyl at position 3 enhanced the activity level $(\mathbf{1 1 h}, \mathrm{MIC}=0.011 \mu \mathrm{g} / \mathrm{mL})$. In the case of two methyl groups at positions 2 and 3 , the activity was reduced $(\mathbf{1 1} \mathbf{j}, \mathrm{MIC}=0.157 \mu \mathrm{g} / \mathrm{mL})$. The activities of 2,4-dichloro derivatives were generally better than those encountered with 2,4-difluorinated products. However, none of the proposed pharmacomodulations retained the activity obtained with the unsubstituted indole. In this case, the inactivity of the 2,3-dimethylindole unit was even more pronounced. The conjugated steric effect of the methyl groups on positions 2 and 3 on the indole ring may have been the cause for this decrease in activity, by imposing an unfavorable position of the indole in the active site of the enzyme.

Overall, it emerged that the synthesized compounds showed activity against C. albicans comparable with or greater than fluconazole. For example, difluoro derivatives (8d and 11h) and dichloro derivatives (8g and 11i) were the most active derivatives. In the particular case of compound $\mathbf{8 g},( \pm)-\mathbf{8 g}$ and its $(-)-(S)$ enantiomer were $\approx 80$ times more active than FLC against C. albicans CA98001.

The activity spectrum on Candida species (Table 2) shows that compound $\mathbf{8 g}$ and more particularly its (S)-enantiomer maintained a better activity than FLC against the various strains tested, especially on those naturally resistant to FLC. For example, on C. krusei, the MIC values of $(S)-8 g$ were between 0.167 and $0.039 \mu \mathrm{g} / \mathrm{mL}$. 
Table 2. MIC ${ }^{1}(\mu \mathrm{g} / \mathrm{mL})$ spectrum of compounds $\mathbf{8 a}-\mathbf{g}$, 11a-k, ketoconazole (KTC), and FLC.

\begin{tabular}{ccccccccc}
\hline Compound & ATCC2091 & CA98002 & CA98005 & ATCC6258 & CK98002 & CK98003 & CL98001 & ATCC90018 \\
\hline $\mathbf{8 a}$ & 0.131 & 0.205 & 0.148 & $>33.5$ & 12.761 & 28.597 & 0.231 & 2.11 \\
$\mathbf{8 b}$ & 0.215 & 0.165 & 0.106 & $>35.2$ & 2.723 & $>35.183$ & 0.222 & 1.3 \\
$\mathbf{8 c}$ & 0.357 & 0.25 & 0.21 & $>39.6$ & 5.076 & 36.565 & 0.25 & 1.84 \\
$\mathbf{8 d}$ & 0.726 & 0.609 & 0.439 & 3.863 & 5.692 & 5.205 & 0.068 & 0.614 \\
$\mathbf{8 e}$ & 0.19 & 0.251 & 0.274 & 1.2 & 1.8 & 0.28 & 0.116 & 0.24 \\
$\mathbf{1 1} \mathbf{1 1}$ & 2.12 & 0.32 & 0.258 & 22.121 & 18.306 & 16.225 & 0.173 & 2.466 \\
$\mathbf{1 1 a}$ & 0.437 & 0.404 & 0.437 & 19.24 & 21.426 & 18.668 & 0.259 & 2.523 \\
$\mathbf{1 1 b}$ & 0.258 & 0.261 & 0.222 & 2.434 & 12.666 & 2.434 & 0.208 & 2.046 \\
$\mathbf{1 1 c}$ & 0.477 & 0.338 & 0.286 & 1.51 & 2.463 & 2.503 & 0.215 & 2.026 \\
$\mathbf{1 1 d}$ & 0.021 & 0.026 & 0.064 & 2.181 & 1.55 & 24.05 & 0.021 & 0.201 \\
$\mathbf{8 g}$ & $<0.004$ & $<0.004$ & $<0.004$ & 0.08 & 2.788 & 3.563 & $<0.004$ & 0.15 \\
$\mathbf{( + ) - ( R ) - 8 g}$ & 1.007 & 2.75 & 2.707 & 24.398 & 22.074 & 19.363 & 9.682 & $>38.726$ \\
$\mathbf{( - ) - ( S ) - 8 g}$ & $<0.039$ & $<0.039$ & 0.026 & 0.167 & 0.022 & 0.039 & 0.024 & 0.027 \\
$\mathbf{8 f}$ & 0.247 & 0.233 & 0.749 & 19.091 & 10.557 & 3.068 & 0.199 & 2 \\
$\mathbf{1 1 f}$ & 0.199 & 0.302 & 0.516 & 17.572 & 7.589 & 5.452 & 0.232 & 2.505 \\
$\mathbf{1 1 g}$ & 0.526 & 0.321 & 0.269 & $>40$ & $>40$ & $>40$ & 0.181 & $>40$ \\
$\mathbf{1 1 h}$ & 0.136 & 0.033 & 0.265 & 1.4 & 0.81 & 0.7 & 0.023 & 0.309 \\
$\mathbf{1 1 i}$ & 0.026 & 0.044 & 0.03 & 3.01 & 0.803 & 1.685 & 0.025 & 0.245 \\
$\mathbf{1 1 j}$ & 0.256 & 0.382 & 2.409 & 17.97 & 11.472 & 13.92 & 0.256 & 4.015 \\
$\mathbf{1 1 k}$ & 2.741 & 1.121 & 2.99 & 25.293 & 20.226 & $>41.532$ & 2.866 & 9.76 \\
$\mathbf{~ K T C}$ & 0.008 & 0.009 & 0.006 & 0.079 & 0.37 & 0.43 & 0.007 & 0.064 \\
$\mathbf{F L C}$ & 0.07 & 1 & 0.57 & 7.5 & 2 & 6.7 & 0.55 & 0.6 \\
\hline
\end{tabular}

${ }^{1} \mathrm{MIC}\left(\mathrm{IC}_{80}, \mu \mathrm{g} / \mathrm{mL}\right)$ was expressed as the mean of triplicate measures. ATCC strains are reference strains (American Type Culture Collection). ATCC2091 is a Candida albicans strain. ATCC6258 is a Candida krusei strain. ATCC90018 is a Candida parapsilosis strain. $\mathrm{CA}=$ Candida albicans. $\mathrm{CK}=$ Candida $\mathrm{krusei} . \mathrm{CL}=$ Candida lusitaniae.

\subsubsection{Toxicity of Selected Compounds on Human Fetal Lung Fibroblast (MRC-5) Cells}

The in vitro toxicity of compounds $\mathbf{8 a}-\mathbf{g}$ and 11a- $\mathbf{k}$ was evaluated on MRC- 5 cells. The results are shown in Table 3. In the imidazole sub-series (compounds 8a-e and 11e), the cytotoxicity $\left(\mathrm{IC}_{50}=31-50 \mu \mathrm{M}\right)$ was approximatively 1.4 to 2.2 times higher than that of ketoconazole (KTC) $\left(\mathrm{IC}_{50}=69.1 \mu \mathrm{M}\right)$. Comparison of this sub-series with the 1,2,4-triazole sub-series (unsubstituted indole derivatives 11a, 11b, and 11d) has shown that the triazole moiety decreased significantly the cytotoxicity $\left(\mathrm{IC}_{50}>100 \mu \mathrm{M}\right)$, except for the 4-bromo derivative $11 \mathrm{c}\left(\mathrm{IC}_{50}=38 \mu \mathrm{M}\right), \mathbf{8 g}$, and its enantiomers. Indeed, the cytotoxicity values of $\mathbf{8 g}$, $(+)-(R)-8 \mathrm{~g}$, and (-)-(S)-8g ( $\mathrm{IC}_{50}=35 \mu \mathrm{M}[28], 32$, and $30 \mu \mathrm{M}$, respectively) were two times higher than that of KTC and at least three times higher than those of FLC $\left(\mathrm{IC}_{50}>100 \mu \mathrm{M}\right)$.

The presence of a methyl group in position 2 and/or 3 on the indole ring (derivatives 11f-k) was compared with the unsubstituted indole derivatives. With a 2,4-difluorinated 11f phenyl ring $(\approx 190 \mu \mathrm{M})$, the presence of a methyl at position 2 did not change the cytotoxicity on MRC- 5 cells when compared to compound 11d $(\approx 197 \mu \mathrm{M})$. On the contrary, with a 2,4-dicholorinated 11g phenyl ring (=157 $\mu \mathrm{M})$, a methyl group at position 2 decreased the cytotoxicity on MRC- 5 cells when compared to compound $8 \mathrm{~g}(=35 \mu \mathrm{M})$. On the other hand, the presence of a methyl group at position 3 led to a two-fold increase in cytotoxicity for 11h (2,4-difluoro derivative, $\left.\mathrm{IC}_{50}=105.4 \mu \mathrm{M}\right)$ and for $11 \mathrm{i}$ as well (2,4-dichloro derivative, $\left.\mathrm{IC}_{50}=19 \mu \mathrm{M}\right)$. In the sub-series of 2,3-dimethyl derivatives, the cytotoxicity was increased with $11 \mathbf{j}$ (2,4-difluoro derivative, $\left.\mathrm{IC}_{50}=25 \mu \mathrm{M}\right)$ compared with compound 11d $(\approx 197 \mu \mathrm{M})$. In the case of 11k (2,4-dichloro derivative, $\left.\mathrm{IC}_{50} \approx 97 \mu \mathrm{M}\right)$, the cytotoxicity on MRC-5 cells was decreased compared with compound $8 \mathrm{~g}(=35 \mu \mathrm{M})$. While the presence of a methyl group on the indole ring globally increased the cytotoxicity of the 2,4-difluoro derivatives $11 \mathrm{~h}$ and $\mathbf{1 1} \mathbf{j}$, the introduction of a methyl group in position 2 into 2,4-dichlorinated products seemed to give less cytotoxic compounds (e.g. 11g, 11k). 
Table 3. Cytotoxicity activity on MRC-5 cells of propanol derivatives $\mathbf{8 a -} \mathbf{g}$ and $\mathbf{1 1 a}-\mathbf{k}$.

\begin{tabular}{cc}
\hline Compound & IC $_{\mathbf{5 0}} \mathbf{1}^{(\mu \mathrm{M})}$ \\
\hline $\mathbf{8 a}$ & 50 \\
$\mathbf{8 b}$ & 37 \\
$\mathbf{8 c}$ & 31 \\
$\mathbf{8 d}$ & 34 \\
$\mathbf{8 e}$ & 31 \\
$\mathbf{1 1 e}$ & 36 \\
$\mathbf{1 1 a}$ & $>100$ \\
$\mathbf{1 1 b}$ & $>100$ \\
$\mathbf{1 1 c}$ & 38 \\
$\mathbf{1 1 d}$ & 197.2 \\
$\mathbf{8 g}$ & 35.0 \\
$\mathbf{( + ) - ( R ) - 8 g}$ & 32 \\
$\mathbf{( - ) - ( S ) - 8 g}$ & 30 \\
$\mathbf{8 f}$ & 76 \\
$\mathbf{1 1 f}$ & 190.7 \\
$\mathbf{1 1 g}$ & 157 \\
$\mathbf{1 1 h}$ & 105.4 \\
$\mathbf{1 1 i}$ & 19 \\
$\mathbf{1 1 j}$ & 25 \\
$\mathbf{1 1 k}$ & 97.3 \\
$\mathbf{K T C}$ & 69.1 \\
$\mathbf{F L C}$ & $>100$ \\
\hline
\end{tabular}

${ }^{1} \mathrm{IC}_{50}$ (half-maximal inhibitory concentration) values $(\mu \mathrm{M})$ were expressed as the mean of triplicate measures.

${ }^{2}$ Cytotoxicity activity of $\mathbf{8 g}$ previously determined [28].

\subsubsection{Inhibitory Activity on Cytochrome P450 Enzymes}

Triazole derivatives 11d (2,4-difluoro) and 8g (2,4-dichloro) were further investigated for their potential to inhibit diverse cytochrome P450 enzymes. Among our panel, four steroidogenic enzymes involved in the biosynthesis of active steroid hormones were selected. This includes $11 \beta$-hydroxylase (CYP11B1), aldosterone synthase (CYP11B2), 17 $\alpha$-hydroxylase/17,20-lyase (CYP17), and aromatase (CYP19). Another enzyme, retinoic acid 4-hydroxylase (CYP26A1), was also used to check the selectivity of compounds $11 \mathrm{~d}$ and $\mathbf{8 g}$. Due to the presence of $1 \mathrm{H}-1,2,4$-triazole, both compounds could coordinate their $\mathrm{N}-4$ atom with the heme iron of these enzymes. In addition, it is the reason that the majority of reference compounds used in our assays (Table 4) were azole agents such as anastrozole, letrozole, liarozole, BW19 (4-(6-methoxy-1-methyl-3,4-dihydro-naphthalen-2-ylmethyl)-1H-imidazole) [29], and KTC. Aminoglutethimide (AG) and fadrozole possess other nitrogen moieties such as amino and nitrile groups, respectively.

First, compounds 11d, 8g, and its enantiomers were tested against CYP19 at $36 \mu \mathrm{M}$. Only 11d $\left(\mathrm{IC}_{50} 3.58 \mu \mathrm{M}\right), 8 \mathrm{~g}$, and its enantiomers $(+)-(R)$ and $(-)-(S)$ (\% inhibition of 27,51 , and 72 , respectively) were weak inhibitors of CYP19. Some studies described inhibitory activities of FLC against CYP19 $\left(\mathrm{IC}_{50}=26.8,>140\right.$ or $=300 \mu \mathrm{M}$, depending on the method used [30,31]). Comparing $(-)-(S)-8 \mathrm{~g}$ with letrozole, the most potent non-steroidal inhibitor $\left(\mathrm{IC}_{50}=0.025 \mathrm{nM}\right)$, there was no significant activity for our antifungal agent against CYP19. In the opposite way, all works undertaken around the indole and the design of non-steroidal aromatase inhibitors $[18,19,32-36]$ helped us to design our first antifungal azolyl-substituted indoles [22,23]. 
Table 4. Selectivity of compounds $\mathbf{1 1 d}, \mathbf{8 g}$, and its enantiomers on a panel of human P450-dependent enzymes (CYP19, CYP17, CYP26A1, CYP11B1, and CYP11B2).

\begin{tabular}{|c|c|c|c|c|c|}
\hline Compound & $\begin{array}{c}\mathrm{CYP19}^{1} \mathrm{IC}_{50}(\mu \mathrm{M}) \\
(\% \text { Inhibition) }\end{array}$ & $\begin{array}{c}\mathrm{CYP17}^{2} \mathrm{IC}_{50}(\mu \mathrm{M}) \\
\text { (\% Inhibition) }\end{array}$ & $\begin{array}{l}\text { CYP26A1 } \\
\mathrm{IC}_{50}(\mu \mathrm{M})\end{array}$ & $\begin{array}{c}\mathrm{CYP11B1}^{4} \mathrm{IC}_{50}(\mu \mathrm{M}) \\
\text { (Inhibition Effect) }\end{array}$ & $\begin{array}{c}\mathrm{CYP11B2}^{4} \mathrm{IC}_{50}(\mu \mathrm{M}) \\
\text { (Inhibtion Effect) }\end{array}$ \\
\hline 11d & $\begin{array}{l}3.58 \\
(89)\end{array}$ & $\begin{array}{c}- \\
\text { (no inhibition) }\end{array}$ & - & - & - \\
\hline $8 \mathrm{~g}$ & $\begin{array}{c}- \\
(27)\end{array}$ & $\begin{array}{c}- \\
(<10 \%)\end{array}$ & - & no inhibition & $\begin{array}{c}- \\
\text { slight inhibition }\end{array}$ \\
\hline$(+)-(R)-8 g$ & $\begin{array}{c}- \\
(51)\end{array}$ & $(<5 \%$ inhibition $)$ & $\begin{array}{l}34 \\
-\end{array}$ & no inhibition & $\begin{array}{c}- \\
\text { slight inhibition }\end{array}$ \\
\hline$(-)-(S)-8 \mathrm{~g}$ & $\begin{array}{c}- \\
(72)\end{array}$ & $(<5 \%$ inhibition $)$ & $\begin{array}{l}18 \\
-\end{array}$ & no inhibition & no inhibition \\
\hline AG & 29.75 & - & - & - & - \\
\hline fadrozole & 0.030 & not active & - & - & - \\
\hline anastrozole & 0.163 & - & - & - & - \\
\hline letrozole & 0.025 & - & - & - & - \\
\hline liarozole & - & - & 7 & - & - \\
\hline BW19 & - & 0.15 & - & - & - \\
\hline KTC & - & 4.5 & 10 & - & - \\
\hline
\end{tabular}

${ }^{1}$ Values are the mean of at least two experiments performed in duplicate. $\%$ inhibition was determined at $36 \mu \mathrm{M} .{ }^{2}$ Values are the mean of two experiments performed in duplicate. \% inhibition was determined at $2.5 \mu \mathrm{M} .{ }^{3}$ The $\mathrm{IC}_{50}$ values are the mean $( \pm 5 \%)$ of two experiments. ${ }^{4}$ The results were obtained from three to four independent experiments.

For CYP17, all compounds tested (11d, $8 \mathrm{~g}$, and its enantiomers) were either inactive or very weak inhibitors. For example, $8 \mathrm{~g}$ gave an inhibitory effect below $10 \%$ at $2.5 \mu \mathrm{M}$. The range was very significant with BW19 and KTC, with $\mathrm{IC}_{50}$ values of 0.15 and $4.5 \mu \mathrm{M}$, respectively.

The enantiomers of $8 \mathrm{~g}$ were evaluated for inhibitory activity against retinoic acid 4-hydroxylase (CYP26A1) using a cellular assay. The standards for comparison in the CYP26A1 assay were the broad spectrum CYP inhibitor KTC and liarozole. The $(+)-(R)-8 \mathrm{~g}$ was a very weak inhibitor of CYP26A1 $\left(\mathrm{IC}_{50}=34 \mu \mathrm{M}\right)$, while the $(-)-(S)-8 \mathrm{~g}$ enantiomer also displayed weak inhibitory activity against CYP26A1 $\left(\mathrm{IC}_{50}=18 \mu \mathrm{M}\right)$ compared with $\mathrm{KTC}\left(\mathrm{IC}_{50}=10 \mu \mathrm{M}\right)$ and liarozole $\left(\mathrm{IC}_{50}=7 \mu \mathrm{M}\right)$.

Racemic compound $8 \mathrm{~g}$ and its enantiomers were also tested for their potential inhibitory effect against CYP11B1 and CYP11B2. 8g showed no inhibitory activity against CYP11B1 and only a slight inhibitory effect against CYP11B2 (at high concentrations). Both enantiomers showed no inhibitory activity against CYP11B1. As mentioned before [37], KTC was a strong inhibitor of CYP11B1; on the other hand, FLC was a minor inhibitor. Only $(+)-(R)-8 \mathrm{~g}$ showed a slight inhibitory effect against CYP11B2 (at high concentrations) while KTC exerted 100\% inhibition in another similar study [38].

\subsection{Molecular Modeling Studies}

\subsubsection{Molecular Docking}

The predicted binding pose of (S)-8g (Figure 4) was to some degree consistent with the binding conformation of co-crystallized posaconazole in the Protein Data Bank (PDB) structure (PDB ID: 5FSA [39]) with the nitrogen atom in the triazole ring interacting with the Fe atom in the heme group. However, the predicted binding pose of $(R)-8 g$ (Figure 5 ) was not consistent with the posaconazole pose in its co-crystal structure where the triazole ring was more parallel with the heme group, rather than perpendicular to the heme, that is, a less favorable angle and subsequently a weaker binding interaction would be expected. Therefore, the (S)-8g generated a better docking score and more credible binding pose compared with $(R)-8 \mathrm{~g}$, which is consistent with the biological experiments described in 2.3.1. 


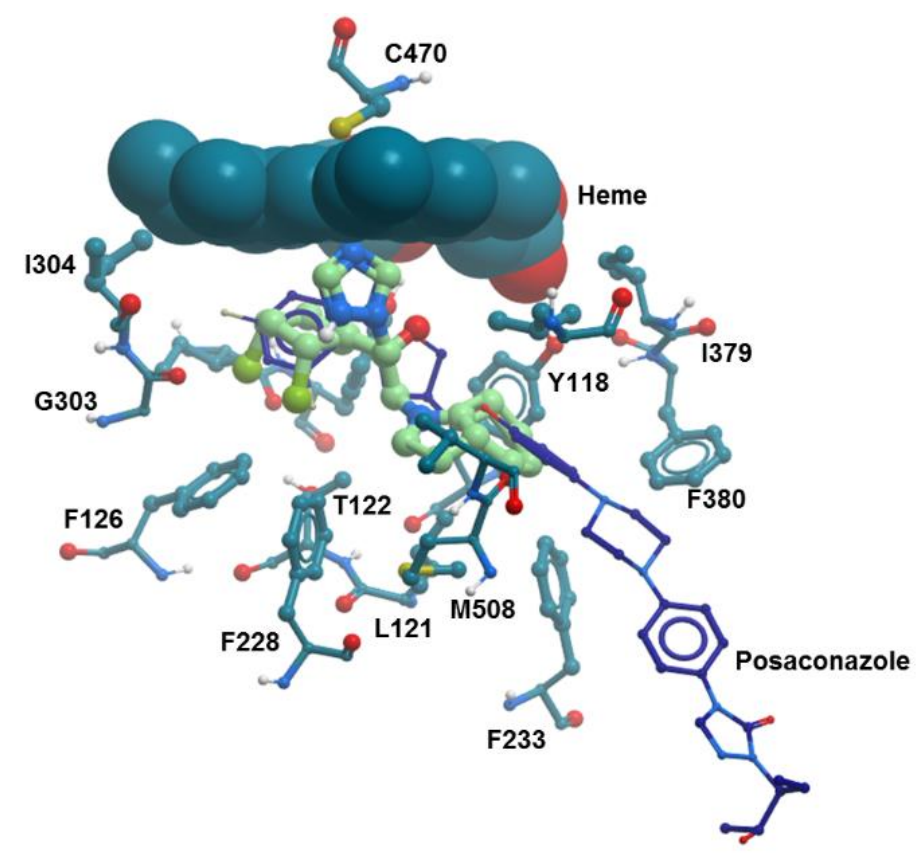

Figure 4. Predicted binding pose of (S)-8g (light green) using CaCYP51.

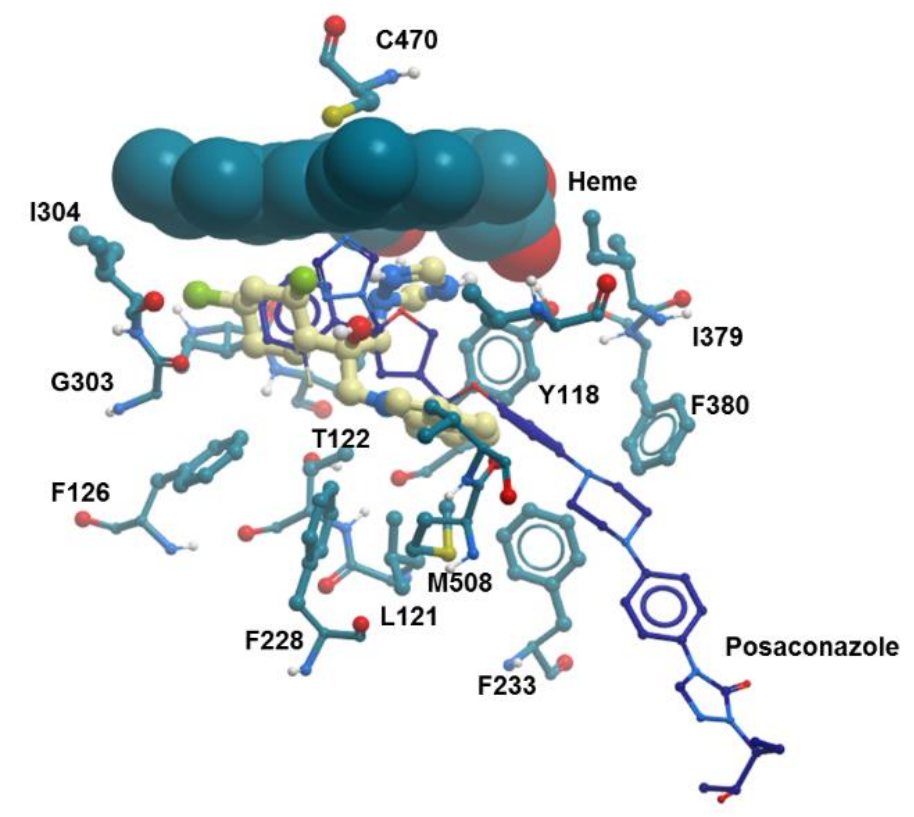

Figure 5. Predicted binding pose of (R)-8g (cream) using CaCYP51.

\subsubsection{Molecular Dynamics Simulation}

In order to confirm the first results obtained by molecular docking, a molecular dynamics (MD) approach was also applied to CaCYP51-azole complexes.

The $(R)$ - and $(S)$-enantiomers of compound $8 \mathbf{g}$ were docked with the CaCYP51 crystal structure (PDB 5FSA [39]) using molecular operating environment (MOE) software [40], and the resulting CaCYP51 (R)-8g and (S)-8g ligand-protein complexes subjected to $100 \mathrm{~ns}$ MD simulations using the Desmond programme of Maestro [41].

Both enantiomers formed primarily hydrophobic interactions including Tyr118, Phe126, and Tyr132 for both enantiomers, Ile304 for (R)-8g, and Leu376 for (S)-8g (Figures 6 and 7). In both enantiomers the dichlorophenyl ring forms a $\pi-\pi$ stacking interaction, with Phe126 and Tyr132 for the $(R)-8 g$ and (S)-8g enantiomer, respectively. Of note is the interaction of the triazole $\mathrm{N}$ with the heme 
iron, which occurred for $75 \%$ of the simulation time for $(R)-8 \mathrm{~g}$ and $100 \%$ of the simulation time for $(S)-8 g$, suggesting improved binding of the $(S)$-enantiomer with the heme active site.

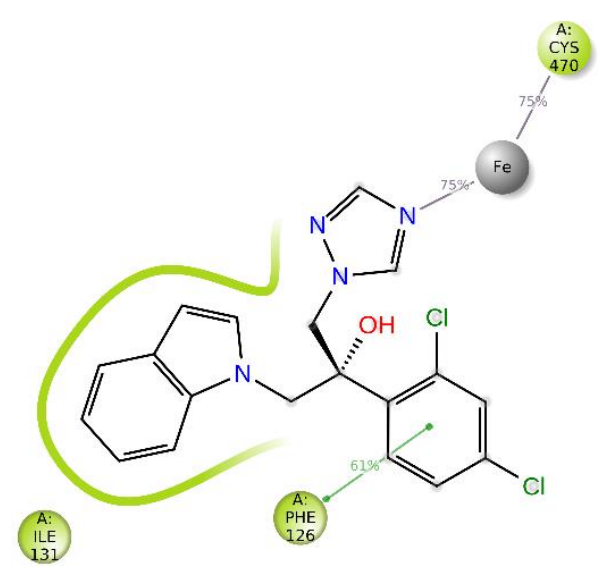

$(R)-8 \mathrm{~g}$

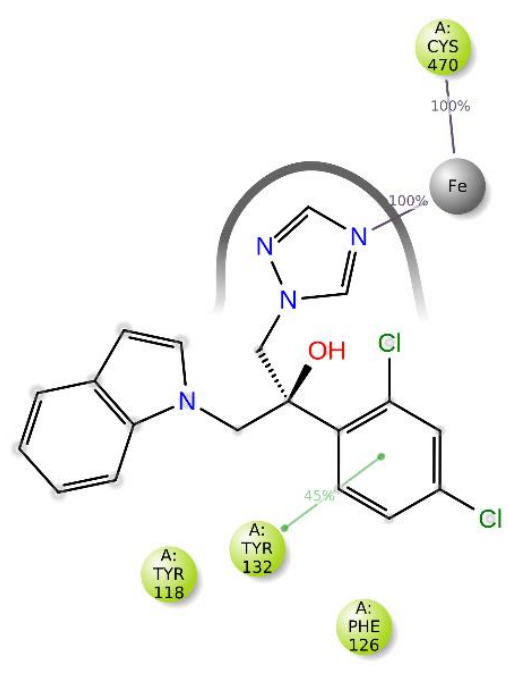

$(S)-8 \mathrm{~g}$

Figure 6. A schematic of detailed ligand atom interactions with the protein residues. Interactions that occur more than $30.0 \%$ of the simulation time in the selected trajectory ( 0.00 through $100.00 \mathrm{~ns})$ are shown.

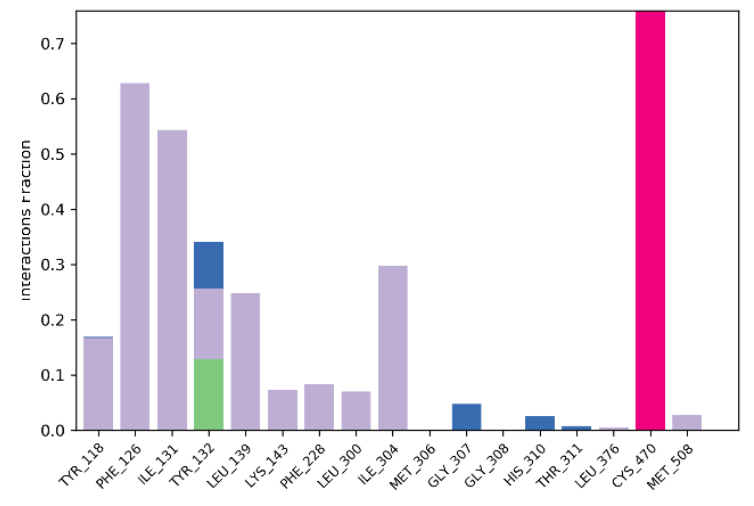

$(R)-8 \mathrm{~g}$

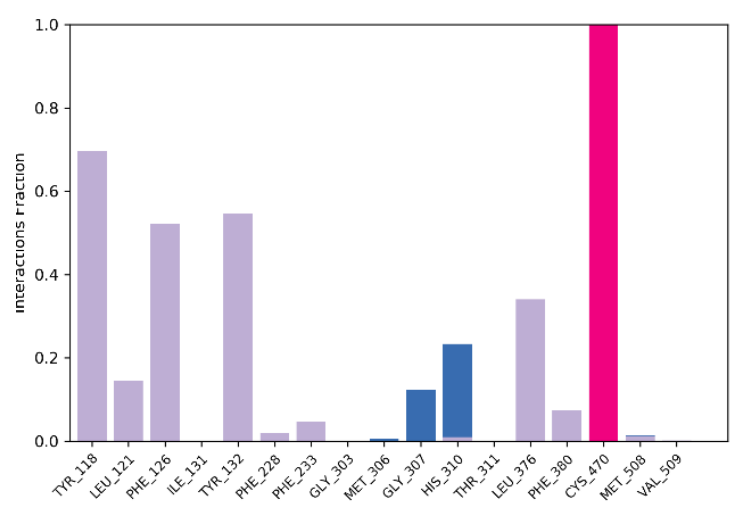

$(S)-8 g$

Figure 7. A schematic of detailed ligand atom interactions of $(R)-\mathbf{8 g}$ and $(S)-\mathbf{8} \mathbf{g}$ with the protein residues of wild-type CaCYP51 protein. Interactions that occur more than $30.0 \%$ of the simulation time in the selected trajectory (0 through $100 \mathrm{~ns}$ ) are shown. (Hydrophobic (purple), water bridges (blue), H-bonds (green), ionic (pink)).

The reason for the reduced binding interaction of the $(R)$-enantiomer of $8 \mathrm{~g}$ can be seen from the 3D image after MD simulation (Figure 8). For optimal binding of the triazole nitrogen with the heme iron, the triazole should have been positioned perpendicular to the heme as observed for the $(S)-8 \mathrm{~g}$ enantiomer; however, the triazole of the $(R)-8 \mathrm{~g}$ enantiomer was positioned parallel to the heme, reducing optimal binding. The unfavorable position of the $(R)$-enantiomer triazole also increased the distance between the triazole $\mathrm{N}$ and the heme iron to $3.11 \AA$ compared with $2.43 \AA$ for the optimally positioned (S)-enantiomer. 


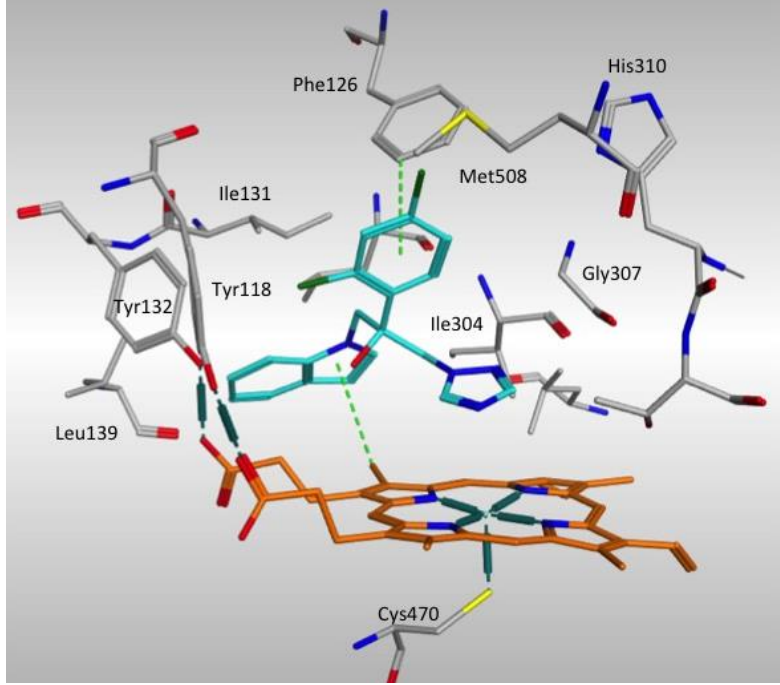

$(R)-8 \mathrm{~g}$

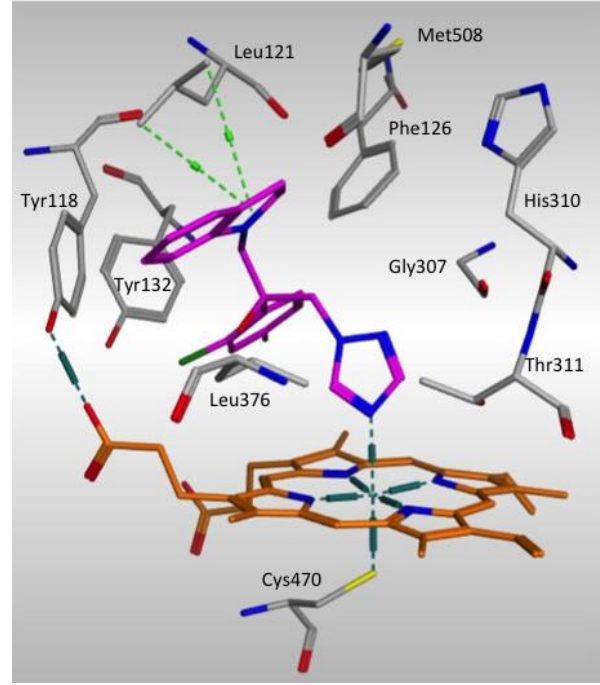

$(S)-8 g$

Figure 8. 3D images of (R)-8g (cyan) and (S)-8g (magenta) ligand-CaCYP51 protein complexes after MD simulation, showing key binding amino acids and positioning of the triazole ring above the heme (orange).

The overlap of both enantiomers of $\mathbf{8 g}$ and posaconazole shows that the (S)-enantiomer aligned with the positioning of posaconazole within both the heme and access channel binding sites, whereas for the $(R)$-enantiomer the dichlorophenyl was outside the small aryl binding pocket and the indole was directed away from the access channel (Figure 9).

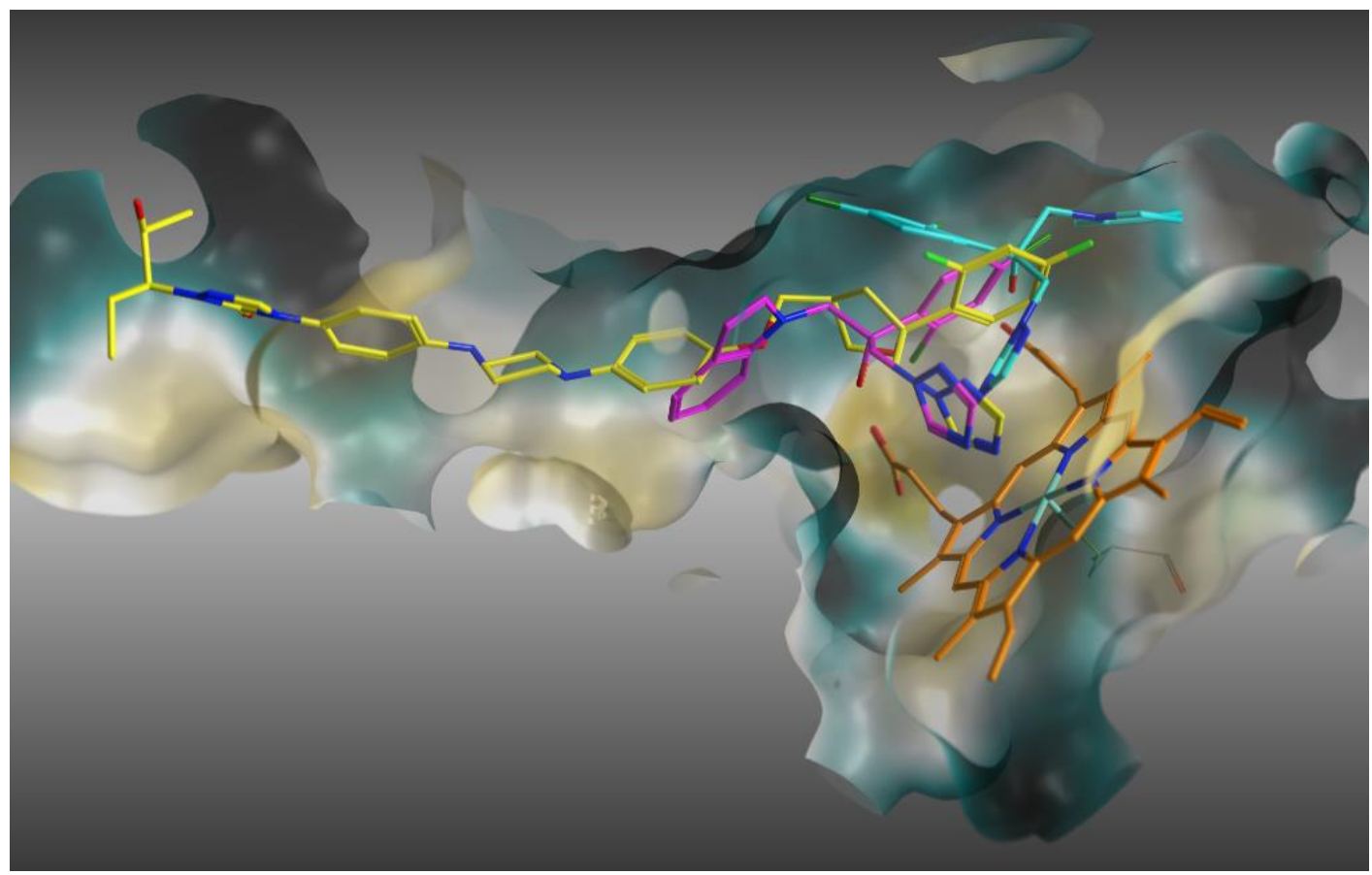

Figure 9. CaCYP51-posaconazole complex (PDB 5FSA) with posaconazole (yellow) positioned along the access channel and above the heme (orange). (R)-8g (cyan) and (S)-8g (magenta) are aligned after MD simulations. 


\section{Materials and Methods}

\subsection{Chemistry}

The microwave reactor was a monomode system (Discover, CEM) with focused waves operating at $2.45 \mathrm{GHz}$. Melting points were determined on an Electrothermal IA9300 melting point digital apparatus and were reported uncorrected. Infrared (IR) spectra were obtained in $\mathrm{KBr}$ pellets or neat liquid films with a Perkin-Elmer Paragon FTIR 1000 PC spectrometer. ${ }^{1} \mathrm{H}$ and ${ }^{13} \mathrm{C}-\mathrm{NMR}$ spectra were recorded on a Bruker AC 250 or AVANCE 400 spectrometer in DMSO- $d_{6}$ as solvent. Chemical shifts $(\delta)$ were reported in part per million (ppm) relative to tetramethylsilane as internal standard. The splitting pattern abbreviations are as follows: s, singlet; $d$, doublet; $t$, triplet; $q$, quartet; $\mathrm{m}$, multiplet; dd, doublet of doublet; $\mathrm{td}$, triplet of doublet. Coupling constants J were given in Hz. Mass spectral (MS) analysis was performed on a quadrupole H.P. 5889A instrument using EI mode at 70 eV. Microanalyses were performed on a Perkin-Elmer CHN 240 apparatus. All reactions were monitored by TLC, using 0.25 mm-thick precoated silica gel plates (E. Merck, Darmstadt, Germany). Compounds were purified by column chromatography using silica gel 60 as a stationary phase. All common chemicals and solvents utilized were reagent grade and purchased from Sigma-Aldrich (Saint Quentin, France).

The synthesis of key intermediates $9 \mathbf{a}-\mathbf{e}$ and 10a-e was previously described by IICiMed (Nantes) [27]. 1-Hydroxymethyl-1H-benzotriazole (2), 1-chloromethyl-1H-benzotriazole (3), and 1-(1H-benzotriazol-1-yl-methyl)- $1 H$-indole (4) were previously published $[42,43]$ and some spectral data were added to be as precise as possible.

\subsection{Synthesis of Compounds $\mathbf{8 a}-\mathbf{g}$ (Route 1)}

\subsubsection{Procedure for the Synthesis of 1-Hydroxymethyl-1H-benzotriazole (2)}

A solution of $1 H$-benzotriazole (1) $(10 \mathrm{~g}, 83.94 \mathrm{mmol})$ in formaldehyde ( $37 \%$ in aqueous solution, $6.81 \mathrm{~mL}, 83.94 \mathrm{mmol}$ ) was stirred at $\mathrm{rt}$ for $5 \mathrm{~min}$. The precipitate was filtered and recrystallized from THF. 1-Hydroxymethyl-1H-benzotriazole (2) was obtained (94\% yield): White powder; $\mathrm{Rf}=0.45$ (dichloromethane /EtOH: 19/1); mp: 148-150 ${ }^{\circ} \mathrm{C}$ (148-151 ${ }^{\circ} \mathrm{C}$, lit. [42]); IR (KBr): v 3192 (s, OH), 1622, $1510 \mathrm{~cm}^{-1} ;{ }^{1} \mathrm{H}$ NMR (DMSO-d $\left.)_{6}\right): \delta 8.11\left(\mathrm{~d}, 1 \mathrm{H}, J=8.3 \mathrm{~Hz}, \mathrm{H}_{4}\right), 7.95\left(\mathrm{~d}, 1 \mathrm{H}, J=8.3 \mathrm{~Hz}, \mathrm{H}_{7}\right), 7.46-7.62$ $\left(\mathrm{m}, 2 \mathrm{H}, \mathrm{H}_{5}, \mathrm{H}_{6}\right), 7.27(\mathrm{t}, 1 \mathrm{H}, J=7.7 \mathrm{~Hz}, \mathrm{OH}), 6.07\left(\mathrm{~d}, 2 \mathrm{H}, J=7.7 \mathrm{~Hz}, \mathrm{CH}_{2}\right)$.

\subsubsection{Procedure for the Synthesis of 1-Chloromethyl-1H-benzotriazole (3)}

1-Hydroxymethyl-1H-benzotriazole (2) $(8.91 \mathrm{~g}, 59.7 \mathrm{mmol})$ was cooled at $0{ }^{\circ} \mathrm{C}$ and thionyl chloride $(26 \mathrm{~mL}, 360 \mathrm{mmol}$ ) was added dropwise. Then the mixture was stirred and refluxed for $1 \mathrm{~h}$ and the volatile fraction was evaporated under reduced pressure. The residue was dissolved in $\mathrm{MeOH}$ and filtered at rt. 1-Chloromethyl-1H-benzotriazole (3) was obtained (93\% yield): White powder; $\mathrm{Rf}=0.74$ (dichloromethane/EtOH: 19/1); mp: $136-138{ }^{\circ} \mathrm{C}\left(136-138{ }^{\circ} \mathrm{C}\right.$, lit. [42]); IR (KBr): $v 1612,1506,1095 \mathrm{~cm}^{-1}$; ${ }^{1} \mathrm{H} \mathrm{NMR}\left(\mathrm{DMSO}-d_{6}\right): \delta 8.19\left(\mathrm{~d}, 1 \mathrm{H}, J=8.3 \mathrm{~Hz}, \mathrm{H}_{4}\right), 8.06\left(\mathrm{~d}, 1 \mathrm{H}, J=8.4 \mathrm{~Hz}, \mathrm{H}_{7}\right), 7.52-7.76\left(\mathrm{~m}, 2 \mathrm{H}, \mathrm{H}_{5}\right.$, $\left.\mathrm{H}_{6}\right), 6.93\left(\mathrm{~s}, 2 \mathrm{H}, \mathrm{CH}_{2}\right)$.

\subsubsection{Procedure for the Synthesis of 1-(1H-Benzotriazol-1-yl-methyl)-1H-indole (4)}

Sodium hydride $(0.73 \mathrm{~g}, 30.3 \mathrm{mmol})$ was dissolved in DMSO $(30 \mathrm{~mL})$ and $1 H$-indole $(3.23 \mathrm{~g}, 27.6 \mathrm{mmol})$ was added portionwise and the mixture was stirred at $\mathrm{rt}$ for $1 \mathrm{~h}$. Then 1 -chloromethyl-1H-benzotriazole (3) $(4.62 \mathrm{~g}, 27.6 \mathrm{mmol})$ was added and the reaction mixture stirred for $2 \mathrm{~h}$. At the end of this period, the mixture was diluted with $\mathrm{H}_{2} \mathrm{O}(30 \mathrm{~mL})$ and extracted with EtOAc $(3 \times 30 \mathrm{~mL})$. The organic layer was washed with brine $(30 \mathrm{~mL})$, dried over anhydrous sodium sulfate, and the volatile fraction was evaporated under reduced pressure. The residue was crystallized from diisopropyl ether. 1-(1H-Benzotriazol-1-yl-methyl)- $1 H$-indole (4) was obtained (80\% yield): White powder; $\mathrm{Rf}=0.35$ (dichloromethane); $\mathrm{mp}: 176-178{ }^{\circ} \mathrm{C}\left(176-178{ }^{\circ} \mathrm{C}\right.$, lit. [43]); IR (KBr): $v 1616,1511,1349 \mathrm{~cm}^{-1} ;{ }^{1} \mathrm{H}$ NMR (DMSO-d $): \delta 8.15\left(\mathrm{~d}, 1 \mathrm{H}, J=8.4 \mathrm{~Hz}, \mathrm{H}_{4^{\prime}}\right), 8.07(\mathrm{~d}, 1 \mathrm{H}$, $\left.J=8.4 \mathrm{~Hz}, \mathrm{H}_{7^{\prime}}\right), 7.86\left(\mathrm{~d}, 1 \mathrm{H}, J=7.2 \mathrm{~Hz}, \mathrm{H}_{4}\right), 7.85\left(\mathrm{~d}, 1 \mathrm{H}, J=3.3 \mathrm{~Hz}, \mathrm{H}_{2}\right), 7.56\left(\mathrm{~d}, 1 \mathrm{H}, J=7.9 \mathrm{~Hz}, \mathrm{H}_{7}\right), 7.41-7.70$ 
$\left(\mathrm{m}, 2 \mathrm{H}, \mathrm{H}_{5^{\prime}}, \mathrm{H}_{6^{\prime}}\right), 7.28\left(\mathrm{~s}, 2 \mathrm{H}, \mathrm{CH}_{2}\right), 7.24\left(\mathrm{dd}, 1 \mathrm{H}, J=7.9 \mathrm{~Hz}, J=7.2 \mathrm{~Hz}, \mathrm{H}_{6}\right), 7.09\left(\mathrm{dd}, 1 \mathrm{H}, J=J=7.2 \mathrm{~Hz}, \mathrm{H}_{5}\right)$, $6.56\left(\mathrm{~d}, 1 \mathrm{H}, J=3.3 \mathrm{~Hz}, \mathrm{H}_{3}\right)$.

\subsubsection{General Procedure for the Synthesis of Benzotriazole Derivatives 5a-f}

1-(1H-Benzotriazol-1-yl-methyl)-1H-indole (4) (1.88 g, $7.57 \mathrm{mmol})$ in THF (50 mL) was cooled to $-78{ }^{\circ} \mathrm{C}$ under argon, and $\mathrm{n}-\mathrm{BuLi}(1.6 \mathrm{M}$ in THF, $5.67 \mathrm{~mL}, 9.1 \mathrm{mmol})$ was added dropwise, then the mixture was stirred at $-78{ }^{\circ} \mathrm{C}$ for $1 \mathrm{~h}$. At the end of this period, the corresponding ethyl benzoate $(9.46 \mathrm{mmol})$ was added dropwise and the mixture was slowly warmed to rt over a period of $12 \mathrm{~h}$. Then saturated aqueous ammonium chloride solution $(35 \mathrm{~mL})$ was added, the mixture was diluted with $\mathrm{H}_{2} \mathrm{O}(30 \mathrm{~mL})$, and extracted with diethyl ether $(3 \times 40 \mathrm{~mL})$. The organic layer was washed with brine $(40 \mathrm{~mL})$, dried over anhydrous sodium sulfate, and the volatile fraction was evaporated under reduced pressure. The residue was purified by silica gel column chromatography (dichloromethane).

1-[(1H-Benzotriazol-1-yl)(4-fluorobenzoyl)methyl]- $1 H$-indole (5a). White powder (61\% yield); $\mathrm{Rf}=0.29$ (dichloromethane); mp: $121-123{ }^{\circ} \mathrm{C}$; IR (KBr): $v 1701$ (s, C=O), 1594, $1304 \mathrm{~cm}^{-1} ;{ }^{1} \mathrm{H}$ NMR (DMSO- $\left.d_{6}\right)$ : $\delta 9.45(\mathrm{~s}, 1 \mathrm{H}, \mathrm{CH}), 8.09-8.12\left(\mathrm{~m}, 1 \mathrm{H}, \mathrm{H}_{4^{\prime}}\right), 8.03-8.07\left(\mathrm{~m}, 2 \mathrm{H}, \mathrm{H}_{2^{\prime \prime}}, \mathrm{H}_{6^{\prime \prime}}\right), 8.01\left(\mathrm{~d}, 1 \mathrm{H}, J=8.2 \mathrm{~Hz}, \mathrm{H}_{7^{\prime}}\right), 7.90$ $\left(\mathrm{d}, 1 \mathrm{H}, J=8.2 \mathrm{~Hz}, \mathrm{H}_{4}\right), 7.60-7.67\left(\mathrm{~m}, 1 \mathrm{H}, \mathrm{H}_{6^{\prime}}\right), 7.56-7.59\left(\mathrm{~m}, 1 \mathrm{H}, \mathrm{H}_{7}\right), 7.56\left(\mathrm{~d}, 1 \mathrm{H}, J=3.4 \mathrm{~Hz}, \mathrm{H}_{2}\right), 7.44-7.50$ $\left(\mathrm{m}, 1 \mathrm{H}, \mathrm{H}_{5^{\prime}}\right), 7.35-7.42\left(\mathrm{~m}, 2 \mathrm{H}, \mathrm{H}_{3^{\prime \prime}}, \mathrm{H}_{5^{\prime \prime}}\right), 7.22\left(\mathrm{dd}, 1 \mathrm{H}, J=8.2 \mathrm{~Hz}, J=7.1 \mathrm{~Hz}, \mathrm{H}_{6}\right), 7.12(\mathrm{dd}, 1 \mathrm{H}, J=8.2 \mathrm{~Hz}$, $\left.J=7.1 \mathrm{~Hz}, \mathrm{H}_{5}\right), 6.60\left(\mathrm{~d}, 1 \mathrm{H}, J=3.4 \mathrm{~Hz}, \mathrm{H}_{3}\right)$.

1-[(1H-Benzotriazol-1-yl)(4-chlorobenzoyl)methyl]-1H-indole (5b). White powder (61\% yield); $\mathrm{Rf}=0.30$ (dichloromethane); $\mathrm{mp}: 184-185^{\circ} \mathrm{C} ; \mathrm{IR}(\mathrm{KBr}): \vee 1712(\mathrm{~s}, \mathrm{C}=\mathrm{O}), 1587,1323 \mathrm{~cm}^{-1} ;{ }^{1} \mathrm{H}$ NMR (DMSO- $\left.d_{6}\right): \delta 9.46(\mathrm{~s}, 1 \mathrm{H}, \mathrm{CH}), 8.11\left(\mathrm{~d}, 1 \mathrm{H}, J=8.1 \mathrm{~Hz}, \mathrm{H}_{4^{\prime}}\right), 8.00\left(\mathrm{~d}, 1 \mathrm{H}, J=8.2 \mathrm{~Hz}, \mathrm{H}_{7^{\prime}}\right), 8.00(\mathrm{~d}, 2 \mathrm{H}$, $\left.J=8.5 \mathrm{~Hz}, \mathrm{H}_{2^{\prime \prime}}, \mathrm{H}_{6^{\prime \prime}}\right), 7.90\left(\mathrm{~d}, 1 \mathrm{H}, J=8.3 \mathrm{~Hz}, \mathrm{H}_{4}\right), 7.64\left(\mathrm{~d}, 2 \mathrm{H}, J=8.5 \mathrm{~Hz}, \mathrm{H}_{3^{\prime \prime}}, \mathrm{H}_{5^{\prime \prime}}\right), 7.60-7.64(\mathrm{~m}, 1 \mathrm{H}$, $\left.\mathrm{H}_{5^{\prime}}\right), 7.56-7.62\left(\mathrm{~m}, 1 \mathrm{H}, \mathrm{H}_{7}\right), 7.57\left(\mathrm{~d}, 1 \mathrm{H}, J=3.1 \mathrm{~Hz}, \mathrm{H}_{2}\right), 7.47\left(\mathrm{dd}, 1 \mathrm{H}, J=8.2 \mathrm{~Hz}, J=7.9 \mathrm{~Hz}, \mathrm{H}_{6^{\prime}}\right), 7.26$ $\left(\mathrm{dd}, 1 \mathrm{H}, J=7.6 \mathrm{~Hz}, J=7.3 \mathrm{~Hz}, \mathrm{H}_{6}\right), 7.13\left(\mathrm{dd}, 1 \mathrm{H}, J=8.3 \mathrm{~Hz}, J=7.3 \mathrm{~Hz}, \mathrm{H}_{5}\right), 6.61\left(\mathrm{~d}, 1 \mathrm{H}, J=3.1 \mathrm{~Hz}, \mathrm{H}_{3}\right)$.

1-[(1H-Benzotriazol-1-yl)(4-bromobenzoyl)methyl]- $1 H$-indole $(5 \mathrm{c})$. White powder ( $50 \%$ yield); $\mathrm{Rf}=0.40$ (dichloromethane); $\mathrm{mp}: 156-157^{\circ} \mathrm{C} ; \mathrm{IR}(\mathrm{KBr}): \vee 1710(\mathrm{~s}, \mathrm{C}=\mathrm{O}), 1583,1323 \mathrm{~cm}^{-1} ;{ }^{1} \mathrm{H}$ NMR (DMSO- $\left.d_{6}\right): \delta 9.46(\mathrm{~s}, 1 \mathrm{H}, \mathrm{CH}), 8.12\left(\mathrm{~d}, 1 \mathrm{H}, J=8.3 \mathrm{~Hz}, \mathrm{H}_{4^{\prime}}\right), 8.03\left(\mathrm{~d}, 1 \mathrm{H}, J=8.4 \mathrm{~Hz}, \mathrm{H}_{7^{\prime}}\right), 7.92(\mathrm{~d}, 2 \mathrm{H}$, $\left.J=8.6 \mathrm{~Hz}, \mathrm{H}_{2^{\prime \prime}}, \mathrm{H}_{6^{\prime \prime}}\right), 7.89\left(\mathrm{~d}, 1 \mathrm{H}, J=7.2 \mathrm{~Hz}, \mathrm{H}_{4}\right), 7.78\left(\mathrm{~d}, 2 \mathrm{H}, J=8.6 \mathrm{~Hz}, \mathrm{H}_{3^{\prime \prime}}, \mathrm{H}_{5^{\prime \prime}}\right), 7.65(\mathrm{dd}, 1 \mathrm{H}, J=8.4$ $\left.\mathrm{Hz}, J=8.0 \mathrm{~Hz}, \mathrm{H}_{6^{\prime}}\right), 7.57\left(\mathrm{~d}, 1 \mathrm{H}, J=3.3 \mathrm{~Hz}, \mathrm{H}_{2}\right), 7.56-7.60\left(\mathrm{~m}, 1 \mathrm{H}, \mathrm{H}_{7}\right), 7.47(\mathrm{dd}, 1 \mathrm{H}, J=8.3 \mathrm{~Hz}, J=8.0$ $\left.\mathrm{Hz}, \mathrm{H}_{5^{\prime}}\right), 7.26-7.30\left(\mathrm{~m}, 1 \mathrm{H}, \mathrm{H}_{6}\right), 7.16\left(\mathrm{dd}, 1 \mathrm{H}, J=J=7.2 \mathrm{~Hz}, \mathrm{H}_{5}\right), 6.61\left(\mathrm{~d}, 1 \mathrm{H}, J=3.3 \mathrm{~Hz}, \mathrm{H}_{3}\right)$.

1-[(1H-Benzotriazol-1-yl)(4-trifluoromethylbenzoyl)-methyl]-1H-indole (5d). Yellow powder $(75 \%$ yield); mp: $175-177^{\circ} \mathrm{C}$; IR (KBr): $v 1711(\mathrm{~s}, \mathrm{C}=\mathrm{O}), 1598,1330 \mathrm{~cm}^{-1} ;{ }^{1} \mathrm{H}$ NMR (DMSO- $\left.d_{6}\right): \delta 9.55(\mathrm{~s}, 1 \mathrm{H}$, $\mathrm{CH}), 8.21\left(\mathrm{~d}, 2 \mathrm{H}, J=7.9 \mathrm{~Hz}, \mathrm{H}_{2^{\prime \prime}}, \mathrm{H}_{6^{\prime \prime}}\right), 8.12\left(\mathrm{~d}, 1 \mathrm{H}, J=8.6 \mathrm{~Hz}, \mathrm{H}_{4^{\prime}}\right), 8.08\left(\mathrm{~d}, 1 \mathrm{H}, J=8.6 \mathrm{~Hz}, \mathrm{H}_{7^{\prime}}\right), 7.96(\mathrm{~d}$, $\left.2 \mathrm{H}, J=7.9 \mathrm{~Hz}, \mathrm{H}_{3^{\prime \prime}}, \mathrm{H}_{5^{\prime \prime}}\right), 7.93-7.96\left(\mathrm{~m}, 1 \mathrm{H}, \mathrm{H}_{4}\right), 7.67\left(\mathrm{dd}, 1 \mathrm{H}, J=J=8.6 \mathrm{~Hz}, \mathrm{H}_{6^{\prime}}\right), 7.58(\mathrm{~d}, 1 \mathrm{H}, J=3.1$ $\left.\mathrm{Hz}, \mathrm{H}_{2}\right), 7.58-7.61\left(\mathrm{~m}, 1 \mathrm{H}, \mathrm{H}_{7}\right), 7.48\left(\mathrm{dd}, 1 \mathrm{H}, J=J=8.6 \mathrm{~Hz}, \mathrm{H}_{5^{\prime}}\right), 7.28\left(\mathrm{dd}, 1 \mathrm{H}, J=J=7.0 \mathrm{~Hz}, \mathrm{H}_{6}\right), 7.14$ $\left(\mathrm{dd}, 1 \mathrm{H}, J=J=7.0 \mathrm{~Hz}, \mathrm{H}_{5}\right), 6.62\left(\mathrm{~d}, 1 \mathrm{H}, J=3.1 \mathrm{~Hz}, \mathrm{H}_{3}\right)$.

1-[(1H-Benzotriazol-1-yl)(2,4-difluorobenzoyl)methyl]-1H-indole (5e). White powder (41\% yield); $\mathrm{Rf}=0.26$ (dichloromethane); $\mathrm{mp}: 111-113^{\circ} \mathrm{C} ; \mathrm{IR}(\mathrm{KBr}): \vee 1705(\mathrm{~s}, \mathrm{C}=\mathrm{O}), 1580,1334 \mathrm{~cm}^{-1} ;{ }^{1} \mathrm{H}$ NMR (DMSO- $\left.d_{6}\right): \delta 9.02(\mathrm{~s}, 1 \mathrm{H}, \mathrm{CH}), 8.26-8.77\left(\mathrm{~m}, 1 \mathrm{H}, \mathrm{H}_{6^{\prime \prime}}\right), 8.10\left(\mathrm{~d}, 1 \mathrm{H}, J=8.5 \mathrm{~Hz}, \mathrm{H}_{4^{\prime}}\right), 8.02(\mathrm{~d}, 1 \mathrm{H}, J=8.5$ $\left.\mathrm{Hz}, \mathrm{H}_{7^{\prime}}\right), 7.78\left(\mathrm{~d}, 1 \mathrm{H}, J=8.6 \mathrm{~Hz}, \mathrm{H}_{4}\right), 7.62-7.68\left(\mathrm{~m}, 1 \mathrm{H}, \mathrm{H}_{6^{\prime}}\right), 7.61\left(\mathrm{~d}, 1 \mathrm{H}, J=3.1 \mathrm{~Hz}, \mathrm{H}_{2}\right), 7.57(\mathrm{~d}, 1 \mathrm{H}$, $\left.J=7.9 \mathrm{~Hz}, \mathrm{H}_{7}\right)$, 7.44-7.53 (m, 1H, $\left.\mathrm{H}_{5^{\prime}}\right), 7.44-7.47\left(\mathrm{~m}, 1 \mathrm{H}, \mathrm{H}_{3^{\prime \prime}}\right), 7.41-7.44\left(\mathrm{~m}, 1 \mathrm{H}, \mathrm{H}_{5^{\prime \prime}}\right), 7.22(\mathrm{dd}, 1 \mathrm{H}$, $\left.J=7.9 \mathrm{~Hz}, J=7.6 \mathrm{~Hz}, \mathrm{H}_{6}\right), 7.11\left(\mathrm{dd}, 1 \mathrm{H}, J=8.6 \mathrm{~Hz}, J=7.6 \mathrm{~Hz}, \mathrm{H}_{5}\right), 6.59\left(\mathrm{~d}, 1 \mathrm{H}, J=3.1 \mathrm{~Hz}, \mathrm{H}_{3}\right)$.

1-[(1H-Benzotriazol-1-yl)(2,4-dichlorobenzoyl)methyl]-1H-indole (5f). White powder (51\% yield); $\mathrm{Rf}=0.34$ (dichloromethane); $\mathrm{mp}: 141-142{ }^{\circ} \mathrm{C} ; \mathrm{IR}(\mathrm{KBr}): \vee 1714(\mathrm{~s}, \mathrm{C}=\mathrm{O}), 1582,1375 \mathrm{~cm}^{-1} ;{ }^{1} \mathrm{H}$ NMR (DMSO- $\left.d_{6}\right): \delta 9.34(\mathrm{~s}, 1 \mathrm{H}, \mathrm{CH}), 8.14\left(\mathrm{~d}, 1 \mathrm{H}, J=8.3 \mathrm{~Hz}, \mathrm{H}_{4^{\prime}}\right), 8.09\left(\mathrm{~d}, 1 \mathrm{H}, J=8.3 \mathrm{~Hz}, \mathrm{H}_{7^{\prime}}\right), 7.85(\mathrm{~d}, 1 \mathrm{H}$, $\left.J=8.2 \mathrm{~Hz}, \mathrm{H}_{4}\right), 7.71-7.76\left(\mathrm{~m}, 1 \mathrm{H}, \mathrm{H}_{6^{\prime \prime}}\right), 7.68-7.71\left(\mathrm{~m}, 1 \mathrm{H}, \mathrm{H}_{6^{\prime}}\right), 7.59\left(\mathrm{~d}, 1 \mathrm{H}, J=3.1 \mathrm{~Hz}, \mathrm{H}_{2}\right), 7.41-7.50(\mathrm{~m}$, $\left.2 \mathrm{H}, \mathrm{H}_{7}, \mathrm{H}_{5^{\prime}}\right), 7.31-7.39\left(\mathrm{~m}, 1 \mathrm{H}, \mathrm{H}_{3^{\prime \prime}}\right), 7.26\left(\mathrm{dd}, 1 \mathrm{H}, J=7.6 \mathrm{~Hz}, J=7.3 \mathrm{~Hz}, \mathrm{H}_{6}\right), 7.05-7.15\left(\mathrm{~m}, 1 \mathrm{H}, \mathrm{H}_{5^{\prime \prime}}\right)$, $6.99\left(\mathrm{dd}, 1 \mathrm{H}, J=8.2 \mathrm{~Hz}, J=7.3 \mathrm{~Hz}, \mathrm{H}_{5}\right), 6.44\left(\mathrm{~d}, 1 \mathrm{H}, J=3.1 \mathrm{~Hz}, \mathrm{H}_{3}\right)$. 


\subsubsection{General Procedure for the Synthesis of $N$-Substituted- $1 H$-indoles $6 \mathbf{a}-\mathbf{f}$}

The corresponding 1-[(1H-benzotriazol-1-yl)(halogenobenzoyl)methyl]-1H-indole 5a-f (3.00 $\mathrm{mmol})$ in ethanol $(15 \mathrm{~mL})$ and THF $(15 \mathrm{~mL})$ was stirred at rt. Then acetic acid $(3 \mathrm{~mL})$ and zinc $(0.98 \mathrm{~g}, 15 \mathrm{mmol})$ were added, and the reaction mixture was stirred at $35^{\circ} \mathrm{C}$ for $5 \mathrm{~h}$ in an ultrasonic bath. The mixture was filtered on Celite 545 and the filtrate was evaporated under reduced pressure. The residue was diluted with $\mathrm{H}_{2} \mathrm{O}(40 \mathrm{~mL})$ and extracted with EtOAc $(3 \times 40 \mathrm{~mL})$, then the organic layer was washed with $\mathrm{H}_{2} \mathrm{O}(40 \mathrm{~mL})$, dried over anhydrous sodium sulfate, and the volatile fraction was evaporated under reduced pressure. The residue was crystallized from diisopropyl ether.

$N$-(4-Fluorobenzoylmethyl)- $1 H$-indole (6a). White powder (57\% yield); $\mathrm{Rf}=0.61$ (dichloromethane); mp: $153-154{ }^{\circ} \mathrm{C}$; IR (KBr): $v 1691$ (s, C=O), 1597, $1325 \mathrm{~cm}^{-1} ;{ }^{1} \mathrm{H}$ NMR (DMSO-d $)$ ): $\delta 8.19-8.24\left(\mathrm{~m}, 2 \mathrm{H}, \mathrm{H}_{2^{\prime}}\right.$, $\left.\mathrm{H}_{6^{\prime}}\right), 7.60\left(\mathrm{~d}, 1 \mathrm{H}, J=7.4 \mathrm{~Hz}, \mathrm{H}_{4}\right), 7.48-7.51\left(\mathrm{~m}, 2 \mathrm{H}, \mathrm{H}_{3^{\prime}}, \mathrm{H}_{5^{\prime}}\right), 7.37-7.44\left(\mathrm{~m}, 2 \mathrm{H}, \mathrm{H}_{2}, \mathrm{H}_{7}\right), 7.02-7.13\left(\mathrm{~m}, 2 \mathrm{H}, \mathrm{H}_{5}\right.$, $\left.\mathrm{H}_{6}\right), 6.52\left(\mathrm{~d}, 1 \mathrm{H}, \mathrm{J}=3.1 \mathrm{~Hz}, \mathrm{H}_{3}\right), 5.93\left(\mathrm{~s}, 2 \mathrm{H}, \mathrm{CH}_{2}\right)$.

$N$-(4-Chlorobenzoylmethyl)- $1 H$-indole $(6 \mathbf{b})$. White powder ( $66 \%$ yield); $\mathrm{Rf}=0.62$ (dichloromethane); mp: $156-157^{\circ} \mathrm{C}$; IR (KBr): v 1692 (s, C=O), 1586, $1399 \mathrm{~cm}^{-1} ;{ }^{1} \mathrm{H}$ NMR (DMSO-d 6$): \delta 8.12-8.15\left(\mathrm{~m}, 1 \mathrm{H}, \mathrm{H}_{4}\right)$, $7.72\left(\mathrm{~d}, 2 \mathrm{H}, \mathrm{J}=8.6 \mathrm{~Hz}, \mathrm{H}_{2^{\prime}}, \mathrm{H}_{6^{\prime}}\right), 7.58-7.60\left(\mathrm{~m}, 1 \mathrm{H}, \mathrm{H}_{7}\right), 7.37\left(\mathrm{~d}, 2 \mathrm{H}, J=8.6 \mathrm{~Hz}, \mathrm{H}_{3^{\prime}}, \mathrm{H}_{5^{\prime}}\right), 7.35-7.40(\mathrm{~m}, 1 \mathrm{H}$, $\left.\mathrm{H}_{2}\right), 7.04-7.11\left(\mathrm{~m}, 2 \mathrm{H}, \mathrm{H}_{5}, \mathrm{H}_{6}\right), 6.50\left(\mathrm{~d}, 1 \mathrm{H}, \mathrm{J}=3.1 \mathrm{~Hz}, \mathrm{H}_{3}\right), 5.93\left(\mathrm{~s}, 2 \mathrm{H}, \mathrm{CH}_{2}\right)$.

$N$-(4-Bromobenzoylmethyl)- $1 H$-indole (6c). White powder $(66 \%$ yield); $\operatorname{Rf}=0.60$ (dichloromethane); mp: 185-186 ${ }^{\circ} \mathrm{C}$; IR (KBr): $v 1689$ (s, C=O), 1582, $1384 \mathrm{~cm}^{-1} ;{ }^{1} \mathrm{H}$ NMR $\left(\mathrm{DMSO}-d_{6}\right)$ : $\delta 8.07\left(\mathrm{~d}, 2 \mathrm{H}, J=8.5 \mathrm{~Hz}, \mathrm{H}_{2^{\prime}}, \mathrm{H}_{6^{\prime}}\right), 7.87\left(\mathrm{~d}, 2 \mathrm{H}, J=8.5 \mathrm{~Hz}_{1} \mathrm{H}_{3^{\prime}}, \mathrm{H}_{5^{\prime}}\right), 7.60\left(\mathrm{~d}, 1 \mathrm{H}, J=7.3 \mathrm{~Hz}, \mathrm{H}_{4}\right), 7.40$ $\left(\mathrm{d}, 1 \mathrm{H}, J=8.2 \mathrm{~Hz}, \mathrm{H}_{7}\right), 7.35\left(\mathrm{~d}, 1 \mathrm{H}, J=3.1 \mathrm{~Hz}, \mathrm{H}_{2}\right), 7.12\left(\mathrm{dd}, 1 \mathrm{H}, J=8.2 \mathrm{~Hz}, J=7.3 \mathrm{~Hz}, \mathrm{H}_{6}\right), 7.05(\mathrm{dd}, 1 \mathrm{H}$, $\left.J=J=7.3 \mathrm{~Hz}, \mathrm{H}_{5}\right), 6.52\left(\mathrm{~d}, 1 \mathrm{H}, J=3.1 \mathrm{~Hz}, \mathrm{H}_{3}\right), 5.94\left(\mathrm{~s}, 2 \mathrm{H}, \mathrm{CH}_{2}\right)$.

$\mathrm{N}$-(4-Trifluoromethylbenzoylmethyl)- $1 \mathrm{H}$-indole (6d). White powder (45\% yield); mp: $182-185{ }^{\circ} \mathrm{C}$; IR (KBr): v 1690 (s, C=O), 1580, $1382 \mathrm{~cm}^{-1} ;{ }^{1} \mathrm{H}$ NMR (DMSO- $\left.d_{6}\right): \delta 8.33\left(\mathrm{~d}, 2 \mathrm{H}, J=7.6 \mathrm{~Hz}, \mathrm{H}_{2^{\prime}}, \mathrm{H}_{6^{\prime}}\right)$, $8.03\left(\mathrm{~d}, 2 \mathrm{H}, J=7.6 \mathrm{~Hz}, \mathrm{H}_{3^{\prime}}, \mathrm{H}_{5^{\prime}}\right), 7.61\left(\mathrm{~d}, 1 \mathrm{H}, J=8.0 \mathrm{~Hz}, \mathrm{H}_{4}\right), 7.43\left(\mathrm{~d}, 1 \mathrm{H}, J=8.0 \mathrm{~Hz}, \mathrm{H}_{7}\right), 7.38(\mathrm{~d}, 1 \mathrm{H}$, $\left.J=3.1 \mathrm{~Hz}, \mathrm{H}_{2}\right), 7.13\left(\mathrm{dd}, 1 \mathrm{H}, J=J=8.0 \mathrm{~Hz}, \mathrm{H}_{5}\right), 6.93\left(\mathrm{dd}, 1 \mathrm{H}, J=J=8.0 \mathrm{~Hz}, \mathrm{H}_{6}\right), 6.54(\mathrm{~d}, 1 \mathrm{H}, J=3.1 \mathrm{~Hz}$, $\left.\mathrm{H}_{3}\right), 6.02\left(\mathrm{~s}, 2 \mathrm{H}, \mathrm{CH}_{2}\right)$.

$N$-(2,4-Difluorobenzoylmethyl)-1H-indole (6e). White powder $(60 \%$ yield); $\mathrm{Rf}=0.39$ (dichloromethane); mp: 101-103 ${ }^{\circ} \mathrm{C}$; IR (KBr): v 1698 (s, C=O), 1587, $1379 \mathrm{~cm}^{-1} ;{ }^{1} \mathrm{H}$ NMR $\left(\mathrm{DMSO}-d_{6}\right)$ :

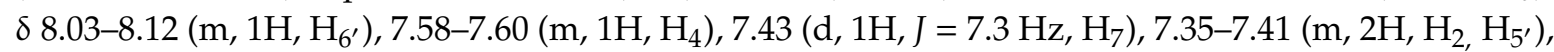
7.31-7.35 (m, 1H, $\left.\mathrm{H}_{3^{\prime}}\right), 7.02-7.11\left(\mathrm{~m}, 2 \mathrm{H}, \mathrm{H}_{5}, \mathrm{H}_{6}\right), 6.51-6.52\left(\mathrm{~m}, 1 \mathrm{H}, \mathrm{H}_{3}\right), 5.79\left(\mathrm{~s}, 2 \mathrm{H}, \mathrm{CH}_{2}\right)$.

$\mathrm{N}$-(4-Dichlorobenzoylmethyl)- $1 H$-indole (6f). White powder (46\% yield); $\mathrm{Rf}=0.64$ (dichloromethane); mp: $98-99{ }^{\circ} \mathrm{C}$; IR (KBr): $v 1704$ (s, C=O), 1580, $1367 \mathrm{~cm}^{-1} ;{ }^{1} \mathrm{H}$ NMR (DMSO-d $)$ ): $\delta 8.04(\mathrm{~d}, 1 \mathrm{H}, \mathrm{J}=8.5 \mathrm{~Hz}$, $\left.\mathrm{H}_{6^{\prime}}\right), 7.83\left(\mathrm{~d}, 1 \mathrm{H}, J=1.4 \mathrm{~Hz}, \mathrm{H}_{3^{\prime}}\right), 7.66-7.70\left(\mathrm{~m}, 1 \mathrm{H}, \mathrm{H}_{5^{\prime}}\right), 7.60\left(\mathrm{~d}, 1 \mathrm{H}, J=7.3 \mathrm{~Hz}, \mathrm{H}_{4}\right), 7.42(\mathrm{~d}, 1 \mathrm{H}, J=7.9 \mathrm{~Hz}$, $\left.\mathrm{H}_{7}\right), 7.38\left(\mathrm{~d}, 1 \mathrm{H}, J=3.1 \mathrm{~Hz}, \mathrm{H}_{2}\right), 7.16\left(\mathrm{dd}, 1 \mathrm{H}, J=7.9 \mathrm{~Hz}, J=7.0 \mathrm{~Hz}, \mathrm{H}_{5}\right), 7.07\left(\mathrm{dd}, 1 \mathrm{H}, J=8.5, J=7.0 \mathrm{~Hz}, \mathrm{H}_{6}\right)$, $6.52\left(\mathrm{~d}, 1 \mathrm{H}, \mathrm{J}=3.1 \mathrm{~Hz}, \mathrm{H}_{3}\right), 5.77\left(\mathrm{~s}, 2 \mathrm{H}, \mathrm{CH}_{2}\right)$.

\subsubsection{General Procedure for the Synthesis of Oxiranes 7a-f}

Trimethylsulfoxonium iodide $(0.44 \mathrm{~g}, 2.02 \mathrm{mmol})$ and sodium hydroxide $(6 \mathrm{~g}, 150 \mathrm{mmol}, 48 \%$ in aqueous solution) were added to a solution of the corresponding $N$-substituted indole $6 \mathbf{a}-\mathbf{f}(1.41 \mathrm{mmol})$ in dichloromethane $(5 \mathrm{~mL})$. Then the reaction mixture was stirred and refluxed for $48 \mathrm{~h}$. At the end of this period, the mixture was diluted with $\mathrm{H}_{2} \mathrm{O}(10 \mathrm{~mL})$ and extracted with dichloromethane $(3 \times 10 \mathrm{~mL})$. The organic layer was washed with $\mathrm{H}_{2} \mathrm{O}(15 \mathrm{~mL})$, dried over anhydrous sodium sulfate, and the volatile fraction was evaporated under reduced pressure. The residue was purified by silica gel column chromatography (dichloromethane/hexane 1:1, v/v).

2-(4-Fluorophenyl)-3-(1H-indol-1-yl)-1,2-epoxypropane (7a). Yellow oil (40\% yield); $\mathrm{Rf}=0.68$ (dichloromethane); IR (NaCl): $v$ 1620, 1366, $1289 \mathrm{~cm}^{-1} ;{ }^{1} \mathrm{H}$ NMR (DMSO-d 6 ): $\delta 7.59(\mathrm{~d}, 1 \mathrm{H}, J=7.6 \mathrm{~Hz}$, $\left.\mathrm{H}_{4^{\prime \prime}}\right)$, 7.49-7.52 (m, 1H, $\left.\mathrm{H}_{7^{\prime \prime}}\right), 7.44-7.49\left(\mathrm{~m}, 2 \mathrm{H}, \mathrm{H}_{2^{\prime}}, \mathrm{H}_{6^{\prime}}\right), 7.27\left(\mathrm{~d}, 1 \mathrm{H}, J=3.1 \mathrm{~Hz}, \mathrm{H}_{2^{\prime \prime}}\right), 7.10-7.17(\mathrm{~m}, 3 \mathrm{H}$, $\left.\mathrm{H}_{3^{\prime}}, \mathrm{H}_{5^{\prime}}, \mathrm{H}_{6^{\prime \prime}}\right), 6.98-7.04\left(\mathrm{~m}, 1 \mathrm{H}, \mathrm{H}_{5^{\prime \prime}}\right), 6.40\left(\mathrm{~d}, 1 \mathrm{H}, \mathrm{J}=3.1 \mathrm{~Hz}, \mathrm{H}_{3^{\prime \prime}}\right), 5.07\left(\mathrm{~d}, 1 \mathrm{H}, \mathrm{J}=15.7 \mathrm{~Hz}, \mathrm{H}_{3}\right), 4.57$ $\left(\mathrm{d}, 1 \mathrm{H}, J=15.7 \mathrm{~Hz}, \mathrm{H}_{3}\right), 2.81\left(\mathrm{~d}, 1 \mathrm{H}, J=4.9 \mathrm{~Hz}, \mathrm{H}_{1}\right), 2.93\left(\mathrm{~d}, 1 \mathrm{H}, J=4.9 \mathrm{~Hz}, \mathrm{H}_{1}\right)$. 
2-(4-Chlorophenyl)-3-(1H-indol-1-yl)-1,2-epoxypropane ( $7 b$ ). Colorless oil (75\% yield); $R f=0.68$ (dichloromethane); IR (NaCl): $v 1598,1315,1270 \mathrm{~cm}^{-1} ;{ }^{1} \mathrm{H}$ NMR (DMSO- $\left.d_{6}\right): \delta 7.58-7.61\left(\mathrm{~m}, 1 \mathrm{H}, \mathrm{H}_{4^{\prime \prime}}\right)$, 7.48-7.51 (m, 1H, $\left.\mathrm{H}_{7^{\prime \prime}}\right), 7.43-7.46\left(\mathrm{~m}, 2 \mathrm{H}, \mathrm{H}_{3^{\prime}}, \mathrm{H}_{5^{\prime}}\right), 7.36\left(\mathrm{~d}, 2 \mathrm{H}, J=8.6 \mathrm{~Hz}, \mathrm{H}_{2^{\prime}}, \mathrm{H}_{6^{\prime}}\right), 7.26(\mathrm{~d}, 1 \mathrm{H}, J=3.1$ $\left.\mathrm{Hz}, \mathrm{H}_{2^{\prime \prime}}\right), 7.10-7.16\left(\mathrm{~m}, 1 \mathrm{H}, \mathrm{H}_{6^{\prime \prime}}\right), 6.97-7.03\left(\mathrm{~m}, 1 \mathrm{H}, \mathrm{H}_{5^{\prime \prime}}\right), 6.38\left(\mathrm{~d}, 1 \mathrm{H}, J=3.1 \mathrm{~Hz}, \mathrm{H}_{3^{\prime \prime}}\right), 5.09(\mathrm{~d}, 1 \mathrm{H}$, $\left.J=15.6 \mathrm{~Hz}, \mathrm{H}_{3}\right), 4.54\left(\mathrm{~d}, 1 \mathrm{H}, J=15.6 \mathrm{~Hz}, \mathrm{H}_{3}\right), 2.95\left(\mathrm{~d}, 1 \mathrm{H}, J=4.9 \mathrm{~Hz}, \mathrm{H}_{1}\right), 2.80\left(\mathrm{~d}, 1 \mathrm{H}, J=4.9 \mathrm{~Hz}, \mathrm{H}_{1}\right)$.

2-(4-Bromophenyl)-3-(1H-indol-1-yl)-1,2-epoxypropane (7c). Colorless oil (37\% yield); $\mathrm{Rf}=0.62$ (dichloromethane); IR (NaCl): $v 1600,1320,1266 \mathrm{~cm}^{-1} ;{ }^{1} \mathrm{H}$ NMR (DMSO- $\left.d_{6}\right): \delta 7.59-7.62\left(\mathrm{~m}, 1 \mathrm{H}, \mathrm{H}_{4^{\prime \prime}}\right)$, $7.51\left(\mathrm{~d}, 2 \mathrm{H}, J=8.5 \mathrm{~Hz}, \mathrm{H}_{3^{\prime}}, \mathrm{H}_{5^{\prime}}\right), 7.42-7.44\left(\mathrm{~m}, 1 \mathrm{H}, \mathrm{H}_{7^{\prime \prime}}\right), 7.40\left(\mathrm{~d}, 2 \mathrm{H}, J=8.5 \mathrm{~Hz}, \mathrm{H}_{2^{\prime}}, \mathrm{H}_{6^{\prime}}\right), 7.29(\mathrm{~d}, 1 \mathrm{H}$, $\left.J=3.1 \mathrm{~Hz}, \mathrm{H}_{2^{\prime \prime}}\right), 7.14\left(\mathrm{dd}, 1 \mathrm{H}, J=8.2 \mathrm{~Hz}, J=7.0 \mathrm{~Hz}, \mathrm{H}_{6^{\prime \prime}}\right), 6.97-7.05\left(\mathrm{~m}, 1 \mathrm{H}, \mathrm{H}_{5^{\prime \prime}}\right), 6.39(\mathrm{~d}, 1 \mathrm{H}, J=3.1 \mathrm{~Hz}$, $\left.\mathrm{H}_{3^{\prime \prime}}\right), 5.11\left(\mathrm{~d}, 1 \mathrm{H}, J=15.6 \mathrm{~Hz}, \mathrm{H}_{3}\right), 4.55\left(\mathrm{~d}, 1 \mathrm{H}, J=15.6 \mathrm{~Hz}, \mathrm{H}_{3}\right), 2.96\left(\mathrm{~d}, 1 \mathrm{H}, J=4.9 \mathrm{~Hz}, \mathrm{H}_{1}\right), 2.81(\mathrm{~d}, 1 \mathrm{H}$, $\left.J=4.9 \mathrm{~Hz}, \mathrm{H}_{1}\right)$.

2-(4-Trifluoromethylphenyl)-3-(1H-indol-1-yl)-1,2-epoxypropane (7d). Yellow oil (62\% yield); IR $(\mathrm{NaCl}): v 1592,1312,1271 \mathrm{~cm}^{-1} ;{ }^{1} \mathrm{H}$ NMR $\left(\mathrm{DMSO}_{6}\right): \delta 7.68\left(\mathrm{~s}, 4 \mathrm{H}, \mathrm{H}_{2^{\prime}}, \mathrm{H}_{3^{\prime}}, \mathrm{H}_{5^{\prime}}, \mathrm{H}_{6^{\prime}}\right), 7.64(\mathrm{~d}, 1 \mathrm{H}$, $\left.J=8.6 \mathrm{~Hz}, \mathrm{H}_{4^{\prime \prime}}\right), 7.51\left(\mathrm{~d}, 1 \mathrm{H}, J=8.6 \mathrm{~Hz}, \mathrm{H}_{7^{\prime \prime}}\right), 7.29\left(\mathrm{~d}, 1 \mathrm{H}, J=4.0 \mathrm{~Hz}, \mathrm{H}_{2^{\prime \prime}}\right), 7.15(\mathrm{dd}, 1 \mathrm{H}, J=J=8.6 \mathrm{~Hz}$, $\left.\mathrm{H}_{5^{\prime \prime}}\right), 7.02\left(\mathrm{dd}, 1 \mathrm{H}, J=J=8.6 \mathrm{~Hz}, \mathrm{H}_{6^{\prime \prime}}\right), 6.40\left(\mathrm{~d}, 1 \mathrm{H}, J=4.0 \mathrm{~Hz}, \mathrm{H}_{3^{\prime \prime}}\right), 5.20\left(\mathrm{~d}, 1 \mathrm{H}, J=15.3 \mathrm{~Hz}, \mathrm{H}_{3}\right), 4.59$ $\left(\mathrm{d}, 1 \mathrm{H}, J=15.3 \mathrm{~Hz}, \mathrm{H}_{3}\right), 3.03\left(\mathrm{~d}, 1 \mathrm{H}, J=4.9 \mathrm{~Hz}, \mathrm{H}_{1}\right), 2.85\left(\mathrm{~d}, 1 \mathrm{H}, J=4.9 \mathrm{~Hz}, \mathrm{H}_{1}\right)$.

2-(2,4-Difluorophenyl)-3-(1H-indol-1-yl)-1,2-epoxypropane (7e). Yellow oil (59\% yield); $\mathrm{Rf}=0.59$ (dichloromethane); IR (NaCl): $v 1589,1369,1290 \mathrm{~cm}^{-1} ;{ }^{1} \mathrm{H}$ NMR (DMSO- $\left.d_{6}\right): \delta 7.56(\mathrm{~d}, 1 \mathrm{H}, J=7.6 \mathrm{~Hz}$, $\left.\mathrm{H}_{4^{\prime \prime}}\right), 7.52\left(\mathrm{~d}, 1 \mathrm{H}, J=7.6 \mathrm{~Hz}, \mathrm{H}_{7^{\prime \prime}}\right), 7.43\left(\mathrm{~d}, 1 \mathrm{H}, J=7.9 \mathrm{~Hz}, \mathrm{H}_{6^{\prime}}\right), 7.18\left(\mathrm{~d}, 1 \mathrm{H}, J=3.1 \mathrm{~Hz}, \mathrm{H}_{2^{\prime \prime}}\right), 7.11-7.15$ $\left(\mathrm{m}, 1 \mathrm{H}, \mathrm{H}_{3^{\prime}}\right), 7.07-7.10\left(\mathrm{~m}, 1 \mathrm{H}, \mathrm{H}_{5^{\prime}}\right), 6.98-7.04\left(\mathrm{~m}, 1 \mathrm{H}, \mathrm{H}_{6^{\prime \prime}}\right), 6.91-6.98\left(\mathrm{~m}, 1 \mathrm{H}, \mathrm{H}_{5^{\prime \prime}}\right), 6.40(\mathrm{~d}, 1 \mathrm{H}, J=3.1$ $\left.\mathrm{Hz}, \mathrm{H}_{3^{\prime \prime}}\right), 4.81\left(\mathrm{~d}, 1 \mathrm{H}, J=15.5 \mathrm{~Hz}, \mathrm{H}_{3}\right), 4.53\left(\mathrm{~d}, 1 \mathrm{H}, J=15.5 \mathrm{~Hz}, \mathrm{H}_{3}\right), 2.98\left(\mathrm{~d}, 1 \mathrm{H}, J=4.9 \mathrm{~Hz}, \mathrm{H}_{1}\right), 2.91$ $\left(\mathrm{d}, 1 \mathrm{H}, J=4.9 \mathrm{~Hz}, \mathrm{H}_{1}\right)$.

2-(2,4-Dichlorophenyl)-3-(1H-indol-1-yl)-1,2-epoxypropane (7f). Green oil (61\% yield); $R f=0.64$ (dichloromethane); IR (NaCl): $v 1612,1371,1314 \mathrm{~cm}^{-1} ;{ }^{1} \mathrm{H}$ NMR (DMSO- $\left.d_{6}\right): \delta 7.68(\mathrm{~d}, 1 \mathrm{H}, J=1.8 \mathrm{~Hz}$, $\left.\mathrm{H}_{3^{\prime}}\right), 7.52\left(\mathrm{~d}, 1 \mathrm{H}, J=7.3 \mathrm{~Hz}, \mathrm{H}_{4^{\prime \prime}}\right), 7.40\left(\mathrm{~d}, 1 \mathrm{H}, J=7.9 \mathrm{~Hz}, \mathrm{H}_{7^{\prime \prime}}\right), 7.17\left(\mathrm{~d}, 1 \mathrm{H}, J=3.1 \mathrm{~Hz}, \mathrm{H}_{2^{\prime \prime}}\right), 7.09-7.15$ $\left(\mathrm{m}, 1 \mathrm{H}, \mathrm{H}_{6^{\prime \prime}}\right), 7.07-7.11\left(\mathrm{~m}, 1 \mathrm{H}, \mathrm{H}_{5^{\prime}}\right), 7.01-7.04\left(\mathrm{~m}, 1 \mathrm{H}, \mathrm{H}_{6^{\prime}}\right), 6.98-7.04\left(\mathrm{~m}, 1 \mathrm{H}, \mathrm{H}_{5^{\prime \prime}}\right), 6.41(\mathrm{~d}, 1 \mathrm{H}, J=3.1$ $\left.\mathrm{Hz}, \mathrm{H}_{3^{\prime \prime}}\right), 4.90\left(\mathrm{~d}, 1 \mathrm{H}, J=15.6 \mathrm{~Hz}, \mathrm{H}_{3}\right), 4.51\left(\mathrm{~d}, 1 \mathrm{H}, J=15.6 \mathrm{~Hz}, \mathrm{H}_{3}\right), 3.01\left(\mathrm{~d}, 1 \mathrm{H}, J=4.6 \mathrm{~Hz}, \mathrm{H}_{1}\right), 2.90$ $\left(\mathrm{d}, 1 \mathrm{H}, J=4.6 \mathrm{~Hz}, \mathrm{H}_{1}\right)$.

\subsubsection{General Procedure for the Synthesis of Imidazole Derivatives 8a-e}

Potassium carbonate $(0.25 \mathrm{~g}, 1.83 \mathrm{mmol})$ and $1 \mathrm{H}$-imidazole $(0.12 \mathrm{~g}, 1.82 \mathrm{mmol})$ were added to a solution of the corresponding oxirane $7 \mathbf{a}-\mathbf{e}(0.64 \mathrm{mmol})$ in dimethylformamide $(20 \mathrm{~mL})$. Then the reaction mixture was stirred and refluxed for $7 \mathrm{~h}$. At the end of this period, the mixture was diluted with $\mathrm{H}_{2} \mathrm{O}(20 \mathrm{~mL})$ and extracted with EtOAc $(3 \times 40 \mathrm{~mL})$. The organic layer was washed with brine $(40 \mathrm{~mL})$, dried over anhydrous sodium sulfate, and the volatile fraction was evaporated under reduced pressure. The residue was purified by silica gel column chromatography (dichloromethane/ethanol $19: 1, v / v)$.

2-(4-Fluorophenyl)-1-(1H-imidazol-1-yl)-3-(1H-indol-1-yl)propan-2-ol (8a). White powder (50\% yield); $\mathrm{Rf}=0.13$ (dichloromethane /EtOH: 19/1); mp: 166-167 ${ }^{\circ} \mathrm{C}$; IR (KBr): $v 3438$ (w, OH), 1607, 1329 $\mathrm{cm}^{-1} ;{ }^{1} \mathrm{H}$ NMR (DMSO- $\left.d_{6}\right): \delta 7.44-7.49\left(\mathrm{~m}, 2 \mathrm{H}, \mathrm{H}_{4^{\prime \prime \prime}}, \mathrm{H}_{7^{\prime \prime \prime}}\right), 7.35\left(\mathrm{~s}, 1 \mathrm{H}, \mathrm{H}_{2^{\prime \prime}}\right), 7.15(\mathrm{~d}, 1 \mathrm{H}, J=3.1 \mathrm{~Hz}$, $\left.\mathrm{H}_{2^{\prime \prime \prime}}\right), 6.87\left(\mathrm{~s}, 1 \mathrm{H}, \mathrm{H}_{4^{\prime \prime}}\right), 6.72\left(\mathrm{~s}, 1 \mathrm{H}, \mathrm{H}_{5^{\prime \prime}}\right), 6.97-7.09\left(\mathrm{~m}, 6 \mathrm{H}, \mathrm{H}_{5^{\prime \prime \prime}}, \mathrm{H}_{6^{\prime \prime \prime}}, \mathrm{H}_{2^{\prime}}, \mathrm{H}_{3^{\prime}}, \mathrm{H}_{5^{\prime}}, \mathrm{H}_{6^{\prime}}\right), 6.37(\mathrm{~d}, 1 \mathrm{H}$, $\left.J=3.1 \mathrm{~Hz}, \mathrm{H}_{3^{\prime \prime \prime}}\right), 5.94(\mathrm{~s}, 1 \mathrm{H}, \mathrm{OH}), 4.63\left(\mathrm{~d}, 1 \mathrm{H}, J=14.4 \mathrm{~Hz}, \mathrm{H}_{3}\right), 4.57\left(\mathrm{~d}, 1 \mathrm{H}, J=14.1 \mathrm{~Hz}, \mathrm{H}_{1}\right), 4.43(\mathrm{~d}, 1 \mathrm{H}$, $\left.J=14.1 \mathrm{~Hz}, \mathrm{H}_{1}\right), 4.29\left(\mathrm{~d}, 1 \mathrm{H}, J=14.4 \mathrm{~Hz}, \mathrm{H}_{3}\right) ; \mathrm{MS} m / z: 335\left(\mathrm{M}^{+}\right), 240,130$ (100), 81. Anal. Calcd. for $\mathrm{C}_{20} \mathrm{H}_{18} \mathrm{FN}_{3} \mathrm{O}$ (335.37): C: 71.62; $\mathrm{H}: 5.37 ; \mathrm{N}: 12.52$; found: $\mathrm{C}: 71.61 ; \mathrm{H}: 5.36 ; \mathrm{N}: 12.50 \%$.

2-(4-Chlorophenyl)-1-(1H-imidazol-1-yl)-3-(1H-indol-1-yl)propan-2-ol (8b). White powder $(60 \%$ yield); $\mathrm{Rf}=0.15$ (dichloromethane $/ \mathrm{EtOH}: 19 / 1) ; \mathrm{mp}: 201-202{ }^{\circ} \mathrm{C} ; \mathrm{IR}(\mathrm{KBr}): \vee 3120(\mathrm{w}, \mathrm{OH}), 1609,1317$ $\mathrm{cm}^{-1} ;{ }^{1} \mathrm{H}$ NMR (DMSO- $\left.d_{6}\right): \delta 7.51\left(\mathrm{~d}, 2 \mathrm{H}, J=8.5 \mathrm{~Hz}, \mathrm{H}_{3^{\prime}}, \mathrm{H}_{5^{\prime}}\right), 7.49\left(\mathrm{~d}, 1 \mathrm{H}, J=7.5 \mathrm{~Hz}, \mathrm{H}_{4^{\prime \prime \prime}}\right), 7.48(\mathrm{~d}, 1 \mathrm{H}$, $\left.J=8.0 \mathrm{~Hz}, \mathrm{H}_{7^{\prime \prime}}\right), 7.35\left(\mathrm{~s}, 1 \mathrm{H}, \mathrm{H}_{2^{\prime \prime}}\right), 7.30\left(\mathrm{~d}, 2 \mathrm{H}, J=8.5 \mathrm{~Hz}, \mathrm{H}_{2^{\prime}}, \mathrm{H}_{6^{\prime}}\right), 7.16\left(\mathrm{~d}, 1 \mathrm{H}, J=3.1 \mathrm{~Hz}, \mathrm{H}_{2^{\prime \prime \prime}}\right), 7.08$ $\left(\mathrm{dd}, 1 \mathrm{H}, J=8.0 \mathrm{~Hz}, J=7.0 \mathrm{~Hz}, \mathrm{H}_{6^{\prime \prime}}\right), 6.98\left(\mathrm{dd}, 1 \mathrm{H}, J=7.5 \mathrm{~Hz}, J=7.0 \mathrm{~Hz}, \mathrm{H}_{5^{\prime \prime \prime}}\right), 6.89\left(\mathrm{~s}, 1 \mathrm{H}, \mathrm{H}_{4^{\prime \prime}}\right), 6.72$ $\left(\mathrm{s}, 1 \mathrm{H}, \mathrm{H}_{5^{\prime \prime}}\right), 6.37\left(\mathrm{~d}, 1 \mathrm{H}, J=3.1 \mathrm{~Hz}, \mathrm{H}_{3^{\prime \prime \prime}}\right), 5.99(\mathrm{~s}, 1 \mathrm{H}, \mathrm{OH}), 4.63\left(\mathrm{~d}, 1 \mathrm{H}, J=14.3 \mathrm{~Hz}, \mathrm{H}_{3}\right), 4.59(\mathrm{~d}, 1 \mathrm{H}$, 
$\left.J=14.4 \mathrm{~Hz}, \mathrm{H}_{1}\right), 4.44\left(\mathrm{~d}, 1 \mathrm{H}, J=14.4 \mathrm{~Hz}, \mathrm{H}_{1}\right), 4.29\left(\mathrm{~d}, 1 \mathrm{H}, J=14.3 \mathrm{~Hz}, \mathrm{H}_{3}\right) ; \mathrm{MS} m / z: 351,353\left(\mathrm{M}^{+}\right), 240$, 130 (100), 81. Anal. Calcd. for $\mathrm{C}_{20} \mathrm{H}_{18} \mathrm{ClN}_{3} \mathrm{O}$ (351.83): C: 68.27; $\mathrm{H}: 5.12 ; \mathrm{N}: 11.94$; found: C: 68.26; $\mathrm{H}$ : $5.11 ; \mathrm{N}: 11.92 \%$.

2-(4-Bromophenyl)-1-(1H-imidazol-1-yl)-3-(1H-indol-1-yl)propan-2-ol (8c). White powder (21\% yield); $\mathrm{Rf}=0.13$ (dichloromethane /EtOH: 19/1); mp: 134-135 ${ }^{\circ} \mathrm{C}$; IR (KBr): $\vee 3054(\mathrm{w}, \mathrm{OH}), 1602,1313$ $\mathrm{cm}^{-1} ;{ }^{1} \mathrm{H}$ NMR (DMSO- $\left.d_{6}\right): \delta 7.62\left(\mathrm{~s}, 1 \mathrm{H}, \mathrm{H}_{2^{\prime \prime}}\right), 7.45-7.51\left(\mathrm{~m}, 5 \mathrm{H}, \mathrm{H}_{2^{\prime}}, \mathrm{H}_{3^{\prime}}, \mathrm{H}_{5^{\prime}}, \mathrm{H}_{6^{\prime}}, \mathrm{H}_{4^{\prime \prime \prime}}\right), 7.45-7.48(\mathrm{~m}$, $\left.1 \mathrm{H}, \mathrm{H}_{7^{\prime \prime \prime}}\right), 7.19\left(\mathrm{~d}, 1 \mathrm{H}, J=3.1 \mathrm{~Hz}, \mathrm{H}_{2^{\prime \prime \prime}}\right), 7.06-7.12\left(\mathrm{~m}, 1 \mathrm{H}, \mathrm{H}_{6^{\prime \prime}}\right), 6.99\left(\mathrm{dd}, 1 \mathrm{H}, J=J=7.0 \mathrm{~Hz}, \mathrm{H}_{5^{\prime \prime \prime}}\right), 6.96$ $\left(\mathrm{s}, 1 \mathrm{H}, \mathrm{H}_{4^{\prime \prime}}\right), 6.87\left(\mathrm{~s}, 1 \mathrm{H}, \mathrm{H}_{5^{\prime \prime}}\right), 6.40\left(\mathrm{~d}, 1 \mathrm{H}, J=3.1 \mathrm{~Hz}, \mathrm{H}_{3^{\prime \prime \prime}}\right), 6.09(\mathrm{~s}, 1 \mathrm{H}, \mathrm{OH}), 4.70(\mathrm{~d}, 1 \mathrm{H}, J=14.3 \mathrm{~Hz}$, $\left.\mathrm{H}_{3}\right), 4.60\left(\mathrm{~d}, 1 \mathrm{H}, J=14.4 \mathrm{~Hz}, \mathrm{H}_{1}\right), 4.48\left(\mathrm{~d}, 1 \mathrm{H}, J=14.4 \mathrm{~Hz}, \mathrm{H}_{1}\right), 4.32\left(\mathrm{~d}, 1 \mathrm{H}, J=14.3 \mathrm{~Hz}, \mathrm{H}_{3}\right) ; \mathrm{MS} m / z$ : 395, $397\left(\mathrm{M}^{+}\right)$, 240, 130 (100), 81. Anal. Calcd. for $\mathrm{C}_{20} \mathrm{H}_{18} \mathrm{BrN}_{3} \mathrm{O}$ (396.28): C: 60.61; H: 4.54; N: 10.60; found: C: $60.58 ; \mathrm{H}: 4.55 ; \mathrm{N}: 10.58 \%$.

2-(2,4-Difluorophenyl)-1-(1H-imidazol-1-yl)-3-(1H-indol-1-yl)propan-2-ol (8d). White powder (50\% yield); $\mathrm{Rf}=0.17$ (dichloromethane $/ \mathrm{EtOH}: 19 / 1) ; \mathrm{mp}: 166-168{ }^{\circ} \mathrm{C} ; \mathrm{IR}(\mathrm{KBr}): \vee 3424(\mathrm{w}, \mathrm{OH}), 1616$, $1317 \mathrm{~cm}^{-1} ;{ }^{1} \mathrm{H}$ NMR (DMSO- $\left.d_{6}\right): \delta 7.49\left(\mathrm{~d}, 1 \mathrm{H}, J=7.6 \mathrm{~Hz}, \mathrm{H}_{4^{\prime \prime \prime}}\right), 7.42\left(\mathrm{~s}, 1 \mathrm{H}, \mathrm{H}_{2^{\prime \prime}}\right), 7.39-7.42(\mathrm{~m}, 1 \mathrm{H}$, $\left.\mathrm{H}_{7^{\prime \prime \prime}}\right)$, 7.25-7.28 (m, 1H, $\left.\mathrm{H}_{6^{\prime}}\right), 7.20-7.21\left(\mathrm{~m}, 2 \mathrm{H}, \mathrm{H}_{2^{\prime \prime \prime}}, \mathrm{H}_{4^{\prime \prime}}\right), 7.07-7.13\left(\mathrm{~m}, 1 \mathrm{H}, \mathrm{H}_{6^{\prime \prime \prime}}\right), 6.98-7.01(\mathrm{~m}, 1 \mathrm{H}$, $\left.\mathrm{H}_{5^{\prime}}\right)$, 6.89-6.95 (m, 1H, $\left.\mathrm{H}_{3^{\prime}}\right), 6.83-6.89\left(\mathrm{~m}, 1 \mathrm{H}, \mathrm{H}_{5^{\prime \prime}}\right), 6.73\left(\mathrm{~s}, 1 \mathrm{H}, \mathrm{H}_{5^{\prime \prime}}\right), 6.39-6.40\left(\mathrm{~m}, 1 \mathrm{H}, \mathrm{H}_{3^{\prime \prime \prime}}\right), 6.24$ $(\mathrm{s}, 1 \mathrm{H}, \mathrm{OH}), 4.68\left(\mathrm{~d}, 1 \mathrm{H}, J=14.4 \mathrm{~Hz}, \mathrm{H}_{3}\right), 4.68\left(\mathrm{~d}, 1 \mathrm{H}, J=14.3 \mathrm{~Hz}, \mathrm{H}_{1}\right), 4.49\left(\mathrm{~d}, 1 \mathrm{H}, J=14.3 \mathrm{~Hz}, \mathrm{H}_{1}\right), 4.30$ (d, $\left.1 \mathrm{H}, J=14.4 \mathrm{~Hz}, \mathrm{H}_{3}\right)$; $\mathrm{MS} m / z: 353\left(\mathrm{M}^{+}\right)$, 240, 130 (100), 81. Anal. Calcd. for $\mathrm{C}_{20} \mathrm{H}_{17} \mathrm{~F}_{2} \mathrm{~N}_{3} \mathrm{O}$ (353.37): C: $67.97 ; \mathrm{H}: 4.81 ; \mathrm{N}: 11.89$; found: C: $67.95 ; \mathrm{H}: 4.79 ; \mathrm{N}: 11.86 \%$.

2-(2,4-Dichlorophenyl)-1-(1H-imidazol-1-yl)-3-(1H-indol-1-yl)propan-2-ol (8e). White powder (70\% yield); $\mathrm{Rf}=0.16$ (dichloromethane /EtOH: 19/1); mp: 212-213 ${ }^{\circ} \mathrm{C}$; IR (KBr): $\vee 3408(\mathrm{w}, \mathrm{OH}), 1609$, $1329 \mathrm{~cm}^{-1} ;{ }^{1} \mathrm{H}$ NMR (DMSO- $\left.d_{6}\right): \delta 7.98\left(\mathrm{~s}, 1 \mathrm{H}, \mathrm{H}_{2^{\prime \prime}}\right), 7.57-7.61\left(\mathrm{~m}, 1 \mathrm{H}, \mathrm{H}_{3^{\prime}}\right), 7.44-7.48\left(\mathrm{~m}, 1 \mathrm{H}, \mathrm{H}_{4^{\prime \prime \prime}}\right)$, $7.36\left(\mathrm{~d}, 1 \mathrm{H}, J=8.5 \mathrm{~Hz}, \mathrm{H}_{7^{\prime \prime}}\right), 7.23\left(\mathrm{~d}, 1 \mathrm{H}, J=3.1 \mathrm{~Hz}, \mathrm{H}_{2^{\prime \prime \prime}}\right), 7.16-7.19\left(\mathrm{~m}, 2 \mathrm{H}, \mathrm{H}_{4^{\prime}}, \mathrm{H}_{5^{\prime}}\right), 7.05-7.11(\mathrm{~m}, 1 \mathrm{H}$, $\left.\mathrm{H}_{6^{\prime \prime \prime}}\right), 6.91\left(\mathrm{~s}, 1 \mathrm{H}, \mathrm{H}_{4^{\prime \prime}}\right), 6.87-6.91\left(\mathrm{~m}, 1 \mathrm{H}, \mathrm{H}_{5^{\prime \prime \prime}}\right), 6.68\left(\mathrm{~s}, 1 \mathrm{H}, \mathrm{H}_{5^{\prime \prime}}\right), 6.35\left(\mathrm{~d}, 1 \mathrm{H}, J=3.1 \mathrm{~Hz}, \mathrm{H}_{3^{\prime \prime \prime}}\right), 6.01$ $(\mathrm{s}, 1 \mathrm{H}, \mathrm{OH}), 5.15\left(\mathrm{~d}, 1 \mathrm{H}, J=14.4 \mathrm{~Hz}, \mathrm{H}_{3}\right), 4.96\left(\mathrm{~d}, 1 \mathrm{H}, J=14.3 \mathrm{~Hz}, \mathrm{H}_{1}\right), 4.75\left(\mathrm{~d}, 1 \mathrm{H}, J=14.3 \mathrm{~Hz}, \mathrm{H}_{1}\right), 4.47$ $\left(\mathrm{d}, 1 \mathrm{H}, J=14.4 \mathrm{~Hz}, \mathrm{H}_{3}\right) ; \mathrm{MS} m / z: 385,387,389\left(\mathrm{M}^{+}\right)$, 240, $130(100)$, 81. Anal. Calcd. for $\mathrm{C}_{20} \mathrm{H}_{17} \mathrm{Cl}_{2} \mathrm{~N}_{3} \mathrm{O}$ (386.27): C: 62.18; H: 4.40; N: 10.87; found: C: 62.20; H: 4.43; N: 10.88\%.

\subsubsection{General Procedure for the Synthesis of Triazole Derivatives $\mathbf{8 f}$ and $\mathbf{8 g}$}

Potassium carbonate $(0.25 \mathrm{~g}, 1.83 \mathrm{mmol})$ and 1,2,4-1 $\mathrm{H}$-triazole $(0.13 \mathrm{~g}, 1.82 \mathrm{mmol})$ were added to a solution of the corresponding oxirane $7 \mathbf{d}, \mathbf{f}(0.64 \mathrm{mmol})$ in dimethylformamide $(20 \mathrm{~mL})$. Then the reaction mixture was stirred and refluxed for $7 \mathrm{~h}$. At the end of this period, the mixture was diluted with $\mathrm{H}_{2} \mathrm{O}(20 \mathrm{~mL})$ and extracted with EtOAc $(40 \mathrm{~mL})$. The organic layer was washed with brine $(40 \mathrm{~mL})$, dried over anhydrous sodium sulfate, and the volatile fraction was evaporated under reduced pressure. The residue was purified by silica gel column chromatography (dichloromethane/ethanol 19:1, v/v).

1-(1H-Indol-1-yl)-3-(1,2,4-1H-triazol-1-yl)-2-(4-trifluoromethyl-phenyl)propan-2-ol (8f). White powder (86\% yield); mp: $165-168{ }^{\circ} \mathrm{C}$; IR (KBr): $v 3420(\mathrm{w}, \mathrm{OH}), 1613,1307 \mathrm{~cm}^{-1} ;{ }^{1} \mathrm{H}$ NMR (DMSO- $\left.d_{6}\right)$ : $\delta 8.32\left(\mathrm{~s}, 1 \mathrm{H}, \mathrm{H}_{3^{\prime \prime}}\right), 7.88\left(\mathrm{~s}, 1 \mathrm{H}, \mathrm{H}_{5^{\prime \prime}}\right), 7.68\left(\mathrm{~d}, 2 \mathrm{H}, J=8.0 \mathrm{~Hz}, \mathrm{H}_{3^{\prime \prime}}, \mathrm{H}_{5^{\prime \prime \prime}}\right), 7.58\left(\mathrm{~d}, 2 \mathrm{H}, J=8.0 \mathrm{~Hz}, \mathrm{H}_{2^{\prime \prime}}, \mathrm{H}_{6^{\prime \prime}}\right)$, $7.48\left(\mathrm{~d}, 1 \mathrm{H}, J=7.6 \mathrm{~Hz}, \mathrm{H}_{4^{\prime}}\right), 7.40\left(\mathrm{~d}, 1 \mathrm{H}, J=7.6 \mathrm{~Hz}, \mathrm{H}_{7^{\prime}}\right), 7.29\left(\mathrm{~d}, 1 \mathrm{H}, J=2.8 \mathrm{~Hz}, \mathrm{H}_{2^{\prime}}\right), 7.03(\mathrm{dd}, 1 \mathrm{H}$, $\left.J=7.6 \mathrm{~Hz}, \mathrm{H}_{6^{\prime}}\right), 6.96\left(\mathrm{dd}, 1 \mathrm{H}, J=7.6 \mathrm{~Hz}, \mathrm{H}_{5^{\prime}}\right), 6.41\left(\mathrm{~d}, 1 \mathrm{H}, J=2.8 \mathrm{~Hz}, \mathrm{H}_{3^{\prime}}\right), 6.16(\mathrm{~s}, 1 \mathrm{H}, \mathrm{OH}), 4.92(\mathrm{~d}, 1 \mathrm{H}$, $\left.J=14.9 \mathrm{~Hz}, \mathrm{H}_{1}\right), 4.64\left(\mathrm{~d}, 1 \mathrm{H}, J=14.9 \mathrm{~Hz}, \mathrm{H}_{1}\right), 4.61\left(\mathrm{~s}, 2 \mathrm{H}, \mathrm{H}_{3}\right) ; \mathrm{MS} m / z: 386\left(\mathrm{M}^{+}\right), 241,130(100), 82$. Anal. Calcd. for $\mathrm{C}_{20} \mathrm{H}_{17} \mathrm{~F}_{3} \mathrm{~N}_{4} \mathrm{O}$ (386.37): C: 62.17; $\mathrm{H}: 4.40 ; \mathrm{N}: 14.49$; found: C: 62.12; $\mathrm{H}: 4.41 ; \mathrm{N}: 14.47 \%$.

2-(2,4-Dichlorophenyl)-3-(1H-indol-1-yl)-1-(1H-1,2,4-triazol-1-yl)-propan-2-ol (8g). White powder (45\% yield); $\mathrm{Rf}=0.11(\mathrm{AcOEt} / \mathrm{hexane:} 1 / 1) ; \mathrm{mp}: 161-162{ }^{\circ} \mathrm{C}$; IR $(\mathrm{KBr}): \vee 3423(\mathrm{w}, \mathrm{OH}), 1585,1273 \mathrm{~cm}^{-1}$; ${ }^{1} \mathrm{H}$ NMR (DMSO- $\left.d_{6}\right): \delta 8.32\left(\mathrm{~s}, 1 \mathrm{H}, \mathrm{H}_{3^{\prime \prime \prime}}\right), 7.79\left(\mathrm{~s}, 1 \mathrm{H}, \mathrm{H}_{5^{\prime \prime \prime}}\right), 7.63\left(\mathrm{~d}, 1 \mathrm{H}, J=2.1 \mathrm{~Hz}, \mathrm{H}_{3^{\prime}}\right), 7.50(\mathrm{~d}, 1 \mathrm{H}$, $\left.J=8.2 \mathrm{~Hz}, \mathrm{H}_{6^{\prime}}\right), 7.50\left(\mathrm{~d}, 1 \mathrm{H}, J=7.9 \mathrm{~Hz}, \mathrm{H}_{4^{\prime \prime}}\right), 7.42\left(\mathrm{~d}, 1 \mathrm{H}, J=7.9 \mathrm{~Hz}, \mathrm{H}_{7^{\prime \prime}}\right), 7.23(\mathrm{dd}, 1 \mathrm{H}, J=8.2 \mathrm{~Hz}$, $\left.J=2.1 \mathrm{~Hz}, \mathrm{H}_{5^{\prime}}\right), 7.21-7.23\left(\mathrm{~m}, 1 \mathrm{H}, \mathrm{H}_{2^{\prime \prime}}\right), 7.13\left(\mathrm{dd}, 1 \mathrm{H}, J=J=7.9 \mathrm{~Hz}, \mathrm{H}_{6^{\prime \prime}}\right), 7.01(\mathrm{dd}, 1 \mathrm{H}, J=J=7.9 \mathrm{~Hz}$, $\left.\mathrm{H}_{5^{\prime \prime}}\right), 6.40\left(\mathrm{~d}, 1 \mathrm{H}, J=2.7 \mathrm{~Hz}, \mathrm{H}_{3^{\prime \prime}}\right), 6.36(\mathrm{~s}, 1 \mathrm{H}, \mathrm{OH}), 5.31\left(\mathrm{~d}, 1 \mathrm{H}, J=14.3 \mathrm{~Hz}, \mathrm{H}_{3}\right), 4.88(\mathrm{~d}, 1 \mathrm{H}, J=15.0$ $\left.\mathrm{Hz}, \mathrm{H}_{1}\right), 4.78\left(\mathrm{~d}, 1 \mathrm{H}, J=15.0 \mathrm{~Hz}, \mathrm{H}_{1}\right), 4.55\left(\mathrm{~d}, 1 \mathrm{H}, J=14.3 \mathrm{~Hz}, \mathrm{H}_{3}\right) ;{ }^{13} \mathrm{C}$ NMR (DMSO- $d_{6}$ ): 50.8, 53.4, 76.7, 101.2, 110.1, 118.2, 120.2, 121.1, 127.0, 127.6, 129.6, 129.9, 131.2, 131.3, 133.1, 136.9, 137.0, 145.4, 
151.2; MS m/z: 386, 388, $390\left(\mathrm{M}^{+}\right), 241,130$ (100), 82. Anal. Calcd. for $\mathrm{C}_{19} \mathrm{H}_{16} \mathrm{Cl}_{2} \mathrm{~N}_{4} \mathrm{O}$ (387.26): C: 58.92; H: 4.13; N: 14.46; found: C: $58.89 ; \mathrm{H}: 4.11 ; \mathrm{N}: 14.45 \%$.

\subsection{Synthesis of Compounds $\mathbf{8 g}$ and $\mathbf{1 1 a}-\mathbf{k}$ (Route 2)}

\subsubsection{Synthesis of 2-(1H-Imidazol-1-yl)-1-(4-trifluoromethylphenyl)ethanone (9f)}

To a solution of 2-bromo-4'-trifluoromethylacetophenone $(2.99 \mathrm{~g}, 11.19 \mathrm{mmol})$ in acetonitrile $(40 \mathrm{~mL})$ was added $1 \mathrm{H}$-imidazole $(1.52 \mathrm{~g}, 22.37 \mathrm{mmol})$ and $\mathrm{K}_{2} \mathrm{CO}_{3}(3.09 \mathrm{~g}, 22.37 \mathrm{mmol})$. The reaction mixture was irradiated for $50 \mathrm{~min}$ in a microwave oven, programmed to obtain reflux with a maximum power output of $50 \mathrm{~W}$. After cooling, the mixture was filtered and evaporated under reduce pressure. The residue was diluted with $\mathrm{H}_{2} \mathrm{O}(40 \mathrm{~mL})$ and extracted with dichloromethane $(3 \times 40 \mathrm{~mL})$, then the organic layer was washed with brine $(40 \mathrm{~mL})$, dried over anhydrous sodium sulfate, and the volatile fraction was evaporated under reduced pressure. The residue was purified by silica gel column chromatography (ethanol/dichloromethane 1:10, v/v). 2-(1H-Imidazol-1-yl)-1-(4-trifluoromethylphenyl)ethanone (9f) was obtained ( $80 \%$ yield): White powder; $\mathrm{Rf}=0.80(\mathrm{EtOH} /$ dichloromethane: $1 / 10) ; \mathrm{mp}: 115-116{ }^{\circ} \mathrm{C} ; \mathrm{IR}$ $(\mathrm{KBr}): v 1702(\mathrm{~s}, \mathrm{C}=\mathrm{O}), 1603,1228 \mathrm{~cm}^{-1} ;{ }^{1} \mathrm{H}$ NMR $\left(\mathrm{DMSO}-d_{6}\right): \delta 8.26\left(\mathrm{~d}, 2 \mathrm{H}, J=8.2 \mathrm{~Hz}, \mathrm{H}_{3^{\prime}}, \mathrm{H}_{5^{\prime}}\right) ; 8.02$ $\left(\mathrm{d}, 2 \mathrm{H}, J=8.2 \mathrm{~Hz}, \mathrm{H}_{2^{\prime}}, \mathrm{H}_{6^{\prime}}\right) ; 7.63\left(\mathrm{~s}, 1 \mathrm{H}, \mathrm{H}_{2^{\prime \prime}}\right), 7.17\left(\mathrm{~s}, 1 \mathrm{H}, \mathrm{H}_{4^{\prime \prime}}\right), 6.97\left(\mathrm{~s}, 1 \mathrm{H}, \mathrm{H}_{5^{\prime \prime}}\right), 5.84\left(\mathrm{~s}, 2 \mathrm{H}, \mathrm{H}_{2}\right) .{ }^{13} \mathrm{C}$ NMR (DMSO- $\left.d_{6}\right): \delta 53.3,121.2,124.2\left(\mathrm{q},{ }^{1} J C F=287.1 \mathrm{~Hz}\right), 126.3\left(\mathrm{q}, 2 \mathrm{C},{ }^{3} J C F=3.8 \mathrm{~Hz}\right), 129.2,129.4$, $133.4\left(\mathrm{q},{ }^{2} J C F=32.0 \mathrm{~Hz}\right), 137.4,138.1,193.6$.

\subsubsection{Synthesis of 3-(1H-imidazol-1-yl)-2-(4-trifluoromethylphenyl)-1,2-epoxypropane (10f)}

Trimethylsulfoxonium iodide $(4.59 \mathrm{~g}, 20.85 \mathrm{mmol})$ and sodium hydroxide $(4.17 \mathrm{~g}, 104.26 \mathrm{mmol}, 20 \%$ in aqueous solution) were added to a solution of 2-(1H-imidazol-1-yl)-1-(4-trifluoromethylphenyl)ethanone (9f) $(2.65 \mathrm{~g}, 10.43 \mathrm{mmol})$ in dichloromethane $(50 \mathrm{~mL})$. Then the reaction mixture was stirred and refluxed for $72 \mathrm{~h}$. At the end of this period, the mixture was diluted with $\mathrm{H}_{2} \mathrm{O}(50 \mathrm{~mL})$ and extracted with dichloromethane $(3 \times 50 \mathrm{~mL})$. The organic layer was washed with $\mathrm{H}_{2} \mathrm{O}(50 \mathrm{~mL})$, dried over anhydrous sodium sulfate, and the volatile fraction was evaporated under reduced pressure. The residue was purified by silica gel column chromatography (dichloromethane/ethanol 10:1, $v / v$ ). 3-(1H-Imidazol-1-yl)-2-(4-trifluoromethylphenyl)-1,2-epoxypropane (10f) was obtained (53\% yield): Red oil; $\mathrm{Rf}=0.91\left(\mathrm{EtOH} /\right.$ dichloromethane: 1/10); IR (NaCl): $v 1541,1328,1073 \mathrm{~cm}^{-1} ;{ }^{1} \mathrm{H}$ NMR (DMSO- $\left.d_{6}\right): \delta$ $7.75\left(\mathrm{~d}, 2 \mathrm{H}, J=7.9 \mathrm{~Hz}, \mathrm{H}_{3^{\prime}}, \mathrm{H}_{5^{\prime}}\right) ; 7.64\left(\mathrm{~d}, 2 \mathrm{H}, J=7.9 \mathrm{~Hz}, \mathrm{H}_{2^{\prime}}, \mathrm{H}_{6^{\prime}}\right) ; 7.56\left(\mathrm{~s}, 1 \mathrm{H}, \mathrm{H}_{2^{\prime \prime}}\right) ; 7.10\left(\mathrm{~s}, 1 \mathrm{H}, \mathrm{H}_{4^{\prime \prime}}\right) ; 6.85$ $\left(\mathrm{s}, 1 \mathrm{H}, \mathrm{H}_{5^{\prime \prime}}\right) ; 5.04\left(\mathrm{~d}, 1 \mathrm{H}, J=15.0 \mathrm{~Hz}, \mathrm{H}_{3}\right) ; 4.38\left(\mathrm{~d}, 1 \mathrm{H}, J=15.0 \mathrm{~Hz}, \mathrm{H}_{3}\right) ; 3.10\left(\mathrm{~d}, 1 \mathrm{H}, J=4.9 \mathrm{~Hz}, \mathrm{H}_{1}\right) ; 2.90$ $\left(\mathrm{d}, 1 \mathrm{H}, J=4.9 \mathrm{~Hz}, \mathrm{H}_{1}\right) .{ }^{13} \mathrm{C}$ NMR (DMSO- $\left.d_{6}\right): \delta 49.6,53.8,59.1,118.2,124.1\left(\mathrm{q},{ }^{1} J C F=267.9 \mathrm{~Hz}\right), 125.3(\mathrm{q}, 2 \mathrm{C}$, $\left.{ }^{3} J C F=3.8 \mathrm{~Hz}\right), 126.7,128.3,128.5\left(\mathrm{q},{ }^{2} J C F=31.9 \mathrm{~Hz}\right), 138.1,141.6$.

\subsubsection{General Procedure for the N-Alkylation of Indole Derivatives $8 \mathbf{g}$ and $\mathbf{1 1 a}-\mathbf{k}$}

Sodium hydride $(0.06 \mathrm{~g}, 2.61 \mathrm{mmol})$ was dissolved in DMSO $(20 \mathrm{~mL})$ and the corresponding indole derivative $(2.61 \mathrm{mmol})$ was added portionwise, then the mixture was stirred at $\mathrm{rt}$ for $1 \mathrm{~h}$ under argon. After this period, the corresponding oxirane derivative 10a-f $(2.61 \mathrm{mmol})$ in DMSO $(10 \mathrm{~mL})$ was added and the mixture was stirred for $12 \mathrm{~h}$. At the end of this period, the mixture was diluted with $\mathrm{H}_{2} \mathrm{O}(20 \mathrm{~mL})$ and extracted with ethyl acetate $(3 \times 40 \mathrm{~mL})$. The organic layer was washed with brine $(40 \mathrm{~mL})$, dried over anhydrous sodium sulfate, and the volatile fraction was evaporated under reduced pressure. The residue was purified by silica gel column chromatography (EtOAc/hexane 1:1, v/v).

2-(4-Fluorophenyl)-3-(1H-indol-1-yl)-1-(1H-1,2,4-triazol-1-yl)propan-2-ol (11a). White powder (57\% yield); $\mathrm{Rf}=0.08\left(\mathrm{EtOAc} /\right.$ hexane: 1/1); $\mathrm{mp}: 190-191^{\circ} \mathrm{C}$; $\mathrm{IR}(\mathrm{KBr}): \vee 3408(\mathrm{w}, \mathrm{OH}), 1602,1217 \mathrm{~cm}^{-1}$; ${ }^{1} \mathrm{H}$ NMR (DMSO- $\left.d_{6}\right): \delta 8.27\left(\mathrm{~s}, 1 \mathrm{H}, \mathrm{H}_{3^{\prime \prime \prime}}\right), 7.90\left(\mathrm{~s}, 1 \mathrm{H}, \mathrm{H}_{5^{\prime \prime \prime}}\right), 7.44-7.49\left(\mathrm{~m}, 3 \mathrm{H}, \mathrm{H}_{2^{\prime}}, \mathrm{H}_{6^{\prime}}, \mathrm{H}_{4^{\prime \prime}}\right), 7.40(\mathrm{~d}, 1 \mathrm{H}$, $\left.J=7.0 \mathrm{~Hz}, \mathrm{H}_{4^{\prime \prime}}\right), 7.27\left(\mathrm{~d}, 1 \mathrm{H}, J=3.1 \mathrm{~Hz}, \mathrm{H}_{2^{\prime \prime}}\right), 7.05\left(\mathrm{dd}, 1 \mathrm{H}, J=J=7.0 \mathrm{~Hz}, \mathrm{H}_{6^{\prime \prime}}\right), 7.04(\mathrm{dd}, 2 \mathrm{H}, J=J=8.9$ $\left.\mathrm{Hz}, \mathrm{H}_{3^{\prime}}, \mathrm{H}_{5^{\prime}}\right), 6.97\left(\mathrm{dd}, 1 \mathrm{H}, J=J=7.0 \mathrm{~Hz}, \mathrm{H}_{5^{\prime \prime}}\right), 6.39\left(\mathrm{~d}, 1 \mathrm{H}, J=3.1 \mathrm{~Hz}, \mathrm{H}_{3^{\prime \prime}}\right), 6.00(\mathrm{~s}, 1 \mathrm{H}, \mathrm{OH}), 4.82$ $\left(\mathrm{d}, 1 \mathrm{H}, J=14.3 \mathrm{~Hz}, \mathrm{H}_{3}\right), 4.60\left(\mathrm{~d}, 1 \mathrm{H}, J=15.3 \mathrm{~Hz}, \mathrm{H}_{1}\right), 4.54\left(\mathrm{~d}, 1 \mathrm{H}, J=15.3 \mathrm{~Hz}, \mathrm{H}_{1}\right), 4.53(\mathrm{~d}, 1 \mathrm{H}, J=14.3$ $\left.\mathrm{Hz}, \mathrm{H}_{3}\right) ;{ }^{13} \mathrm{C}$ NMR (DMSO- $\left.d_{6}\right): \delta 53.6,56.1,75.9,100.8,110.3,114.3\left(\mathrm{~d}, 2 \mathrm{C},{ }^{2} J C F=21.5 \mathrm{~Hz}\right), 118.7,120.0$, 
120.7, 127.5, 129.8, $128.0\left(\mathrm{~d}, 2 \mathrm{C},{ }^{3} J C F=8.1 \mathrm{~Hz}\right), 137.0,137.5\left(\mathrm{~d},{ }^{4} J C F=3.3 \mathrm{~Hz}\right), 145.0,150.6,161.3(\mathrm{~d}$, $\left.{ }^{1} J C F=242.7 \mathrm{~Hz}\right)$; MS m/z $336\left(\mathrm{M}^{+}\right), 241,130(100)$, 82. Anal. Calcd. for $\mathrm{C}_{19} \mathrm{H}_{17} \mathrm{FN}_{4} \mathrm{O}$ (336.36): C: 67.84; H: 5.05; N: 16.65; found: C: 67.87; H: 5.03; N: 16.61\%.

2-(2,4-Dichlorophenyl)-3-(1H-indol-1-yl)-1-(1H-1,2,4-triazol-1-yl)propan-2-ol (8g). White powder (38\% yield); all physicochemical and spectral data were similar to $8 \mathrm{~g}$ obtained by route 1 .

2-(4-Chlorophenyl)-3-(1H-indol-1-yl)-1-(1H-1,2,4-triazol-1-yl)propan-2-ol (11b). White powder (89\% yield); $\mathrm{Rf}=0.77(\mathrm{EtOH} /$ dichloromethane: $1 / 10) ; \mathrm{mp}: 188-189^{\circ} \mathrm{C} ; \mathrm{IR}(\mathrm{KBr}): \vee 3408(\mathrm{w}, \mathrm{OH}), 1596$, $1269 \mathrm{~cm}^{-1} ;{ }^{1} \mathrm{H}$ NMR (DMSO- $\left.d_{6}\right): \delta 8.28\left(\mathrm{~s}, 1 \mathrm{H}, \mathrm{H}_{3^{\prime \prime \prime}}\right), 7.89\left(\mathrm{~s}, 1 \mathrm{H}, \mathrm{H}_{5^{\prime \prime \prime}}\right), 7.49\left(\mathrm{~d}, 1 \mathrm{H}, J=7.0 \mathrm{~Hz}, \mathrm{H}_{4^{\prime \prime}}\right)$, $7.47\left(\mathrm{~d}, 2 \mathrm{H}, J=8.9 \mathrm{~Hz}, \mathrm{H}_{2^{\prime}}, \mathrm{H}_{6^{\prime}}\right), 7.44\left(\mathrm{~d}, 1 \mathrm{H}, J=7.0 \mathrm{~Hz}, \mathrm{H}_{7^{\prime \prime}}\right), 7.28\left(\mathrm{~d}, 2 \mathrm{H}, J=8.9 \mathrm{~Hz}, \mathrm{H}_{3^{\prime}}, \mathrm{H}_{5^{\prime}}\right), 7.27$ $\left(\mathrm{d}, 1 \mathrm{H}, J=2.7 \mathrm{~Hz}, \mathrm{H}_{2^{\prime \prime}}\right), 7.06\left(\mathrm{dd}, 1 \mathrm{H}, J=J=7.0 \mathrm{~Hz}, \mathrm{H}_{6^{\prime \prime}}\right), 6.98\left(\mathrm{dd}, 1 \mathrm{H}, J=J=7.0 \mathrm{~Hz}, \mathrm{H}_{5^{\prime \prime}}\right), 6.40(\mathrm{~d}, 1 \mathrm{H}$, $\left.J=2.7 \mathrm{~Hz}, \mathrm{H}_{3^{\prime \prime}}\right), 6.05(\mathrm{~s}, 1 \mathrm{H}, \mathrm{OH}), 4.84\left(\mathrm{~d}, 1 \mathrm{H}, J=14.0 \mathrm{~Hz}, \mathrm{H}_{3}\right), 4.62\left(\mathrm{~d}, 1 \mathrm{H}, J=15.0 \mathrm{~Hz}, \mathrm{H}_{1}\right), 4.60(\mathrm{~d}, 1 \mathrm{H}$, $\left.J=14.0 \mathrm{~Hz}, \mathrm{H}_{3}\right), 4.54\left(\mathrm{~d}, 1 \mathrm{H}, J=15.0 \mathrm{~Hz}, \mathrm{H}_{1}\right) ;{ }^{13} \mathrm{C}$ NMR $\left(\right.$ DMSO- $\left.d_{6}\right): \delta 53.5,56.0,76.0,100.9,110.4,118.7$, 119.9, 120.7, 120.8, 125.1, 127.5 (2C), 127.9 (2C), 129.8, 137.0, 140.4, 145.0, 150.6; MS m/z: $352\left(\mathrm{M}^{+}\right), 354$ $(\mathrm{M}+2), 241,130$ (100), 82. Anal. Calcd. for $\mathrm{C}_{19} \mathrm{H}_{17} \mathrm{ClN}_{4} \mathrm{O}$ (352.82): C: 64.68; H: 4.82; N: 15.87; found: C: 64.64; H: $4.79 ; \mathrm{N}: 15.89 \%$.

2-(4-Bromophenyl)-3-(1H-indol-1-yl)-1-(1H-1,2,4-triazol-1-yl)propan-2-ol (11c). White powder (45\% yield); Rf $=0.09$ (EtOAc/hexane: 1/1); mp: 186-187 ${ }^{\circ} \mathrm{C}$; IR $(\mathrm{KBr}): \vee 3406(\mathrm{w}, \mathrm{OH}), 1587,1271 \mathrm{~cm}^{-1}$; ${ }^{1} \mathrm{H}$ NMR (DMSO- $\left.d_{6}\right): \delta 8.27\left(\mathrm{~s}, 1 \mathrm{H}, \mathrm{H}_{3^{\prime \prime \prime}}\right), 7.88\left(\mathrm{~s}, 1 \mathrm{H}, \mathrm{H}_{5^{\prime \prime \prime}}\right), 7.48\left(\mathrm{~d}, 1 \mathrm{H}, J=7.0 \mathrm{~Hz}, \mathrm{H}_{4^{\prime \prime}}\right), 7.44(\mathrm{~d}, 1 \mathrm{H}$, $\left.J=7.0 \mathrm{~Hz}, \mathrm{H}_{7^{\prime \prime}}\right), 7.41\left(\mathrm{~s}, 4 \mathrm{H}, \mathrm{H}_{2^{\prime}}, \mathrm{H}_{3^{\prime}}, \mathrm{H}_{5^{\prime}}, \mathrm{H}_{6^{\prime}}\right), 7.26\left(\mathrm{~d}, 1 \mathrm{H}, J=3.1 \mathrm{~Hz}, \mathrm{H}_{2^{\prime \prime}}\right), 7.06(\mathrm{dd}, 1 \mathrm{H}, J=J=7.0$ $\left.\mathrm{Hz}, \mathrm{H}_{6^{\prime \prime}}\right), 6.98\left(\mathrm{dd}, 1 \mathrm{H}, J=J=7.0 \mathrm{~Hz}, \mathrm{H}_{5^{\prime \prime}}\right), 6.40\left(\mathrm{~d}, 1 \mathrm{H}, J=3.1 \mathrm{~Hz}, \mathrm{H}_{3^{\prime \prime}}\right), 6.04(\mathrm{~s}, 1 \mathrm{H}, \mathrm{OH}), 4.84(\mathrm{~d}, 1 \mathrm{H}$, $\left.J=14.3 \mathrm{~Hz}, \mathrm{H}_{3}\right), 4.61\left(\mathrm{~d}, 1 \mathrm{H}, J=15.0 \mathrm{~Hz}, \mathrm{H}_{1}\right), 4.57\left(\mathrm{~d}, 1 \mathrm{H}, J=14.3 \mathrm{~Hz}, \mathrm{H}_{3}\right), 4.54(\mathrm{~d}, 1 \mathrm{H}, J=15.0 \mathrm{~Hz}$, $\left.\mathrm{H}_{1}\right) ;{ }^{13} \mathrm{C}$ NMR (DMSO- $d_{6}$ ): $\delta 53.5,55.9,76.0,100.9,110.4,118.7,120.0,120.5,120.8,127.5,128.3(2 \mathrm{C}$ ), 129.8, 130.5 (2C), 137.0, 140.9, 145.0, 150.6; MS m/z: 396, $398\left(\mathrm{M}^{+}\right), 241,130$ (100), 82. Anal. Calcd. for $\mathrm{C}_{19} \mathrm{H}_{17} \mathrm{BrN}_{4} \mathrm{O}$ (397.27): C: 57.44; H: 4.28; N: 14.10; found: C: 57.40; $\mathrm{H}: 4.25 ; \mathrm{N}: 14.08 \%$.

2-(2,4-Difluorophenyl)-3-(1H-indol-1-yl)-1-(1H-1,2,4-triazol-1-yl)-propan-2-ol (11d). White powder (41\% yield); $\mathrm{Rf}=0.08$ (EtOAc/hexane: $1 / 1) ; \mathrm{mp}: 119-120{ }^{\circ} \mathrm{C} ; \mathrm{IR}(\mathrm{KBr}): \vee 3206(\mathrm{w}, \mathrm{OH}), 1615,1313 \mathrm{~cm}^{-1} ;{ }^{1} \mathrm{H}$ NMR (DMSO- $\left.d_{6}\right): \delta 8.34\left(\mathrm{~s}, 1 \mathrm{H}, \mathrm{H}_{3^{\prime \prime \prime}}\right), 7.82\left(\mathrm{~s}, 1 \mathrm{H}, \mathrm{H}_{5^{\prime \prime \prime}}\right), 7.49\left(\mathrm{~d}, 1 \mathrm{H}, J=7.6 \mathrm{~Hz}, \mathrm{H}_{4^{\prime \prime}}\right), 7.39(\mathrm{~d}, 1 \mathrm{H}, J=7.6 \mathrm{~Hz}$, $\left.\mathrm{H}_{7^{\prime \prime}}\right), 7.25\left(\mathrm{~d}, 1 \mathrm{H}, J=3.1 \mathrm{~Hz}, \mathrm{H}_{2^{\prime \prime}}\right), 7.17-7.29\left(\mathrm{~m}, 2 \mathrm{H}, \mathrm{H}_{3^{\prime}}, \mathrm{H}_{5^{\prime}}\right), 7.10\left(\mathrm{dd}, 1 \mathrm{H}, J=J=7.6 \mathrm{~Hz}, \mathrm{H}_{6^{\prime \prime}}\right), 6.99(\mathrm{dd}, 1 \mathrm{H}$, $\left.J=J=7.6 \mathrm{~Hz}, \mathrm{H}_{5^{\prime \prime}}\right), 6.86\left(\mathrm{td}, 1 \mathrm{H}, J=8.6 \mathrm{~Hz}, J=2.4 \mathrm{~Hz}, \mathrm{H}_{2^{\prime}}\right), 6.40\left(\mathrm{~d}, 1 \mathrm{H}, J=3.1 \mathrm{~Hz}, \mathrm{H}_{3^{\prime \prime}}\right), 6.29(\mathrm{~s}, 1 \mathrm{H}, \mathrm{OH}), 4.90$ $\left(\mathrm{d}, 1 \mathrm{H}, J=14.3 \mathrm{~Hz}, \mathrm{H}_{3}\right), 4.68\left(\mathrm{~d}, 1 \mathrm{H}, J=15.0 \mathrm{~Hz}, \mathrm{H}_{1}\right), 4.57\left(\mathrm{~d}, 1 \mathrm{H}, J=15.0 \mathrm{~Hz}, \mathrm{H}_{1}\right), 4.56(\mathrm{~d}, 1 \mathrm{H}, J=14.3 \mathrm{~Hz}$, $\left.\mathrm{H}_{3}\right) ;{ }^{13} \mathrm{C}$ NMR (DMSO- $\left.d_{6}\right): \delta 52.1,54.8,75.2\left(\mathrm{~d},{ }^{3} J C F=5.2 \mathrm{~Hz}\right), 100.9,103.9\left(\mathrm{dd},{ }^{2} J C F={ }^{2} J C F=26.2 \mathrm{~Hz}\right), 111.0$ $\left(\mathrm{dd},{ }^{2} J C F=20.5 \mathrm{~Hz},{ }^{4} J C F=2.9 \mathrm{~Hz}\right), 111.3,118.7,120.0,120.8,124.0\left(\mathrm{dd},{ }^{2} J C F=13.4 \mathrm{~Hz},{ }^{4} J C F=3.8 \mathrm{~Hz}\right), 125.1$, $129.6,130.1\left(\mathrm{dd},{ }^{3} J C F=10.0 \mathrm{~Hz},{ }^{3} J C F=6.7 \mathrm{~Hz}\right), 136.9,145.0,150.7,158.9\left(\mathrm{dd},{ }^{1} J C F=247.0 \mathrm{~Hz},{ }^{3} J C F=12.4\right.$ $\mathrm{Hz}), 162.5\left(\mathrm{dd},{ }^{1} J C F=246.1 \mathrm{~Hz},{ }^{3} J C F=12.9 \mathrm{~Hz}\right) ; \mathrm{MS} m / z: 354\left(\mathrm{M}^{+}\right), 241,130$ (100), 82. Anal. Calcd. for $\mathrm{C}_{19} \mathrm{H}_{16} \mathrm{~F}_{2} \mathrm{~N}_{4} \mathrm{O}$ (354.35): C: 64.40; $\mathrm{H}: 4.52 ; \mathrm{N}: 15.80$; found: C: 64.43; $\mathrm{H}: 4.50 ; \mathrm{N}: 15.84 \%$.

1-(1H-Imidazol-1-yl)-3-(1H-indol-1-yl)-2-(4-trifluoromethylphenyl)propan-2-ol (11e). Orange powder (9\% yield); $\mathrm{Rf}=0.61$ (EtOAc/hexane: 1/1); mp: $246-247^{\circ} \mathrm{C}$; IR $(\mathrm{KBr}): v 3421(\mathrm{w}, \mathrm{OH}), 1610$, $1328 \mathrm{~cm}^{-1} ;{ }^{1} \mathrm{H}$ NMR (DMSO- $\left.d_{6}\right): \delta 7.73\left(\mathrm{~d}, 2 \mathrm{H}, J=8.2 \mathrm{~Hz}, \mathrm{H}_{3^{\prime \prime \prime}}, \mathrm{H}_{5^{\prime \prime}}\right), 7.60\left(\mathrm{~d}, 2 \mathrm{H}, J=8.2 \mathrm{~Hz}, \mathrm{H}_{2^{\prime \prime \prime}}\right.$, $\left.\mathrm{H}_{6^{\prime \prime \prime}}\right), 7.48\left(\mathrm{~d}, 1 \mathrm{H}, J=7.9 \mathrm{~Hz}, \mathrm{H}_{4^{\prime \prime}}\right), 7.45\left(\mathrm{~d}, 1 \mathrm{H}, J=7.9 \mathrm{~Hz}, \mathrm{H}_{7^{\prime \prime}}\right), 7.38\left(\mathrm{~s}, 1 \mathrm{H}, \mathrm{H}_{2^{\prime}}\right), 7.18(\mathrm{~d}, 1 \mathrm{H}, J=3.1 \mathrm{~Hz}$, $\left.\mathrm{H}_{2^{\prime \prime}}\right), 7.07\left(\mathrm{dd}, 1 \mathrm{H}, J=J=7.9 \mathrm{~Hz}, \mathrm{H}_{6^{\prime \prime}}\right), 6.94\left(\mathrm{dd}, 1 \mathrm{H}, J=J=7.9 \mathrm{~Hz}, \mathrm{H}_{5^{\prime \prime}}\right), 6.91\left(\mathrm{~s}, 1 \mathrm{H}, \mathrm{H}_{5^{\prime}}\right), 6.72(\mathrm{~s}, 1 \mathrm{H}$, $\left.\mathrm{H}_{4^{\prime}}\right), 6.38\left(\mathrm{~d}, 1 \mathrm{H}, J=3.1 \mathrm{~Hz}, \mathrm{H}_{3^{\prime \prime}}\right), 6.16(\mathrm{~s}, 1 \mathrm{H}, \mathrm{OH}), 4.72\left(\mathrm{~d}, 1 \mathrm{H}, J=14.3 \mathrm{~Hz}, \mathrm{H}_{3}\right), 4.63(\mathrm{~d}, 1 \mathrm{H}, J=14.7 \mathrm{~Hz}$, $\left.\mathrm{H}_{1}\right), 4.48\left(\mathrm{~d}, 1 \mathrm{H}, J=14.7 \mathrm{~Hz}, \mathrm{H}_{1}\right), 4.35\left(\mathrm{~d}, 1 \mathrm{H}, J=14.3 \mathrm{~Hz}, \mathrm{H}_{3}\right) ;{ }^{13} \mathrm{C}$ NMR (DMSO- $\left.d_{6}\right): \delta 53.6,56.9,76.8$, 100.5, 110.4, 117.4, 119.1, 119.9, 120.6, $124.2\left(\mathrm{q}, 2 \mathrm{C},{ }^{3} J C F=5.7 \mathrm{~Hz}\right), 124.8\left(\mathrm{q},{ }^{1} J C F=263.4 \mathrm{~Hz}\right), 127.2(2 \mathrm{C})$, 127.4, 128.3, $128.9\left(\mathrm{q},{ }^{2} J C F=26.7 \mathrm{~Hz}\right), 130.6,138.1,138.6,139.9 ; \mathrm{MS} m / z: 385\left(\mathrm{M}^{+}\right), 240,130(100), 81$. Anal. Calcd. for $\mathrm{C}_{21} \mathrm{H}_{18} \mathrm{~F}_{3} \mathrm{~N}_{3} \mathrm{O}$ (385.38): C: 65.44; $\mathrm{H}: 4.67 ; \mathrm{N}: 10.90$; found: C: 65.41; H: 4.64; N: 10.87\%.

2-(2,4-Difluorophenyl)-3-(2-methyl-1H-indol-1-yl)-1-(1H-1,2,4-triazol-1-yl)propan-2-ol (11f). Orange powder (34\% yield); $\mathrm{Rf}=0.17$ (EtOAc/hexane: $1 / 10) ; \mathrm{mp}: 125-126^{\circ} \mathrm{C} ; \mathrm{IR}(\mathrm{KBr}): \vee 3113(\mathrm{w}, \mathrm{OH})$, 1612, $1270 \mathrm{~cm}^{-1} ;{ }^{1} \mathrm{H}$ NMR (DMSO- $\left.d_{6}\right): \delta 8.38\left(\mathrm{~s}, 1 \mathrm{H}, \mathrm{H}_{3^{\prime \prime \prime}}\right), 7.82\left(\mathrm{~s}, 1 \mathrm{H}, \mathrm{H}_{5^{\prime \prime \prime}}\right), 7.27-7.42\left(\mathrm{~m}, 2 \mathrm{H}, \mathrm{H}_{3^{\prime}}\right.$, $\left.\mathrm{H}_{5^{\prime}}\right), 7.41\left(\mathrm{~d}, 1 \mathrm{H}, J=7.0 \mathrm{~Hz}, \mathrm{H}_{4^{\prime \prime}}\right), 7.25\left(\mathrm{~d}, 1 \mathrm{H}, J=7.0 \mathrm{~Hz}, \mathrm{H}_{7^{\prime \prime}}\right), 6.96-7.04\left(\mathrm{~m}, 2 \mathrm{H}, \mathrm{H}_{5^{\prime \prime}}, \mathrm{H}_{6^{\prime \prime}}\right), 6.93(\mathrm{td}, 1 \mathrm{H}$, $\left.J=8.2 \mathrm{~Hz}, J=2.4 \mathrm{~Hz}, \mathrm{H}_{6^{\prime}}\right), 6.22\left(\mathrm{~s}, 1 \mathrm{H}, \mathrm{H}_{3^{\prime \prime}}\right), 6.09(\mathrm{~s}, 1 \mathrm{H}, \mathrm{OH}), 4.96\left(\mathrm{~d}, 1 \mathrm{H}, J=14.4 \mathrm{~Hz}, \mathrm{H}_{3}\right), 4.61(\mathrm{~d}, 1 \mathrm{H}$, 
$\left.J=15.3 \mathrm{~Hz}, \mathrm{H}_{1}\right), 4.59\left(\mathrm{~d}, 1 \mathrm{H}, J=14.4 \mathrm{~Hz}, \mathrm{H}_{3}\right), 4.46\left(\mathrm{~d}, 1 \mathrm{H}, J=15.3 \mathrm{~Hz}, \mathrm{H}_{1}\right), 2.22\left(\mathrm{~s}, 3 \mathrm{H}, \mathrm{CH}_{3}\right) ;{ }^{13} \mathrm{C} \mathrm{NMR}$ $\left(\right.$ DMSO- $\left.d_{6}\right): \delta 13.0,52.1,54.8,75.2\left(\mathrm{~d},{ }^{3} J C F=5.2 \mathrm{~Hz}\right), 100.9,103.9\left(\mathrm{dd},{ }^{2} J C F={ }^{2} J C F=26.2 \mathrm{~Hz}\right), 111.0$ $\left(\mathrm{dd},{ }^{2} J C F=20.5 \mathrm{~Hz},{ }^{4} J C F=2.9 \mathrm{~Hz}\right), 111.3,118.7,120.0,120.8,124.0\left(\mathrm{dd},{ }^{2} J C F=3.4 \mathrm{~Hz},{ }^{4} J C F=3.8 \mathrm{~Hz}\right)$, $125.1,129.6,130.1\left(\mathrm{dd},{ }^{3} J C F=10.0 \mathrm{~Hz},{ }^{3} J C F=6.7 \mathrm{~Hz}\right), 136.9,145.0,150.7,158.9\left(\mathrm{dd},{ }^{1} J C F=247.0 \mathrm{~Hz}\right.$, $\left.{ }^{3} J C F=12.4 \mathrm{~Hz}\right), 162.5\left(\mathrm{dd},{ }^{1} J C F=246.1 \mathrm{~Hz},{ }^{3} J C F=12.9 \mathrm{~Hz}\right) ; \mathrm{MS} m / z: 368\left(\mathrm{M}^{+}\right), 255,144(100), 82$. Anal. Calcd. for $\mathrm{C}_{20} \mathrm{H}_{18} \mathrm{~F}_{2} \mathrm{~N}_{4} \mathrm{O}$ (368.38): C: 65.20; $\mathrm{H}: 4.89 ; \mathrm{N}: 15.20$; found: C: 65.18; H: 4.91; N: 15.17\%.

2-(2,4-Dichlorophenyl)-3-(2-methyl-1H-indol-1-yl)-1-(1H-1,2,4-triazol-1-yl)propan-2-ol (11g). White powder (15\% yield); $\mathrm{Rf}=0.30$ (EtOAc/hexane: $1 / 1)$; mp: 170-171 ${ }^{\circ} \mathrm{C}$; IR $(\mathrm{KBr}): v 3422(\mathrm{w}, \mathrm{OH}), 1582,1271$ $\mathrm{cm}^{-1} ;{ }^{1} \mathrm{H}$ NMR (DMSO- $\left.d_{6}\right): \delta 8.40\left(\mathrm{~s}, 1 \mathrm{H}, \mathrm{H}_{3^{\prime \prime \prime}}\right), 7.82\left(\mathrm{~s}, 1 \mathrm{H}, \mathrm{H}_{5^{\prime \prime \prime}}\right), 7.70\left(\mathrm{~d}, 1 \mathrm{H}, J=2.1 \mathrm{~Hz}, \mathrm{H}_{3^{\prime}}\right), 7.49(\mathrm{~d}, 1 \mathrm{H}$, $\left.J=7.2 \mathrm{~Hz}, \mathrm{H}_{6^{\prime}}\right), 7.42\left(\mathrm{~d}, 1 \mathrm{H}, J=8.3 \mathrm{~Hz}, \mathrm{H}_{4^{\prime \prime}}\right), 7.31\left(\mathrm{~d}, 1 \mathrm{H}, J=7.2 \mathrm{~Hz}, \mathrm{H}_{5^{\prime}}\right), 7.23(\mathrm{dd}, 1 \mathrm{H}, J=8.3 \mathrm{~Hz}, J=2.1$ $\left.\mathrm{Hz}, \mathrm{H}_{7^{\prime \prime}}\right), 6.95-7.03\left(\mathrm{~m}, 2 \mathrm{H}, \mathrm{H}_{5^{\prime \prime}}, \mathrm{H}_{6^{\prime \prime}}\right), 6.24\left(\mathrm{~s}, 1 \mathrm{H}, \mathrm{H}_{3^{\prime \prime}}\right), 6.06(\mathrm{~s}, 1 \mathrm{H}, \mathrm{OH}), 5.36\left(\mathrm{~d}, 1 \mathrm{H}, J=14.3 \mathrm{~Hz}, \mathrm{H}_{3}\right), 4.88$ $\left(\mathrm{d}, 1 \mathrm{H}, J=15.4 \mathrm{~Hz}, \mathrm{H}_{1}\right), 4.71\left(\mathrm{~d}, 1 \mathrm{H}, J=14.3 \mathrm{~Hz}, \mathrm{H}_{3}\right), 4.55\left(\mathrm{~d}, 1 \mathrm{H}, J=15.4 \mathrm{~Hz}, \mathrm{H}_{1}\right), 2.25\left(\mathrm{~s}, 3 \mathrm{H}, \mathrm{CH}_{3}\right) ;{ }^{13} \mathrm{C}$ NMR (DMSO- $d_{6}$ ): $\delta 12.9,48.2,53.5,76.6,100.7,110.2,118.9,119.0,120.0,127.2,127.8,130.1,131.1,131.6,133.3$, 137.9, 138.2 (2C), 145.9, 150.8; MS m/z: 400, 402, $404\left(\mathrm{M}^{+}\right)$, 255, 144 (100), 82. Anal. Calcd. for $\mathrm{C}_{20} \mathrm{H}_{18} \mathrm{Cl}_{2} \mathrm{~N}_{4} \mathrm{O}$ (401.29): C: 59.86; H: 4.49; N: 13.95; found: C: 59.84; H: 4.44; N: 13.91\%.

2-(2,4-Difluorophenyl)-3-(3-methyl-1H-indol-1-yl)-1-(1H-1,2,4-triazol-1-yl)propan-2-ol $\quad$ (11h). White powder (35\% yield); $\mathrm{Rf}=0.12$ (EtOAc/hexane: $1 / 10) ; \mathrm{mp}: 112-113^{\circ} \mathrm{C}$; IR $(\mathrm{KBr}): \vee 3421(\mathrm{w}, \mathrm{OH})$, 1617, $1272 \mathrm{~cm}^{-1} ;{ }^{1} \mathrm{H}$ NMR (DMSO- $\left.d_{6}\right): \delta 8.33\left(\mathrm{~s}, 1 \mathrm{H}, \mathrm{H}_{3^{\prime \prime \prime}}\right), 7.80\left(\mathrm{~s}, 1 \mathrm{H}, \mathrm{H}_{5^{\prime \prime}}\right), 7.18-7.30\left(\mathrm{~m}, 2 \mathrm{H}, \mathrm{H}_{3^{\prime}}, \mathrm{H}_{5^{\prime}}\right)$, $7.44\left(\mathrm{~d}, 1 \mathrm{H}, J=7.3 \mathrm{~Hz}, \mathrm{H}_{4^{\prime \prime}}\right), 7.32\left(\mathrm{~d}, 1 \mathrm{H}, J=7.3 \mathrm{~Hz}, \mathrm{H}_{7^{\prime \prime}}\right), 7.12\left(\mathrm{dd}, 1 \mathrm{H}, J=7.3 \mathrm{~Hz}, \mathrm{H}_{6^{\prime \prime}}\right), 7.07\left(\mathrm{~s}, 1 \mathrm{H}, \mathrm{H}_{2^{\prime \prime}}\right)$, $6.99\left(\mathrm{dd}, 1 \mathrm{H}, J=7.3 \mathrm{~Hz}, \mathrm{H}_{5^{\prime \prime}}\right), 6.85\left(\mathrm{td}, 1 \mathrm{H}, J=7.9 \mathrm{~Hz}, J=2.3 \mathrm{~Hz}, \mathrm{H}_{6^{\prime}}\right), 6.25(\mathrm{~s}, 1 \mathrm{H}, \mathrm{OH}), 4.89(\mathrm{~d}, 1 \mathrm{H}$, $\left.J=14.3 \mathrm{~Hz}, \mathrm{H}_{3}\right), 4.54\left(\mathrm{~s}, 2 \mathrm{H}, \mathrm{H}_{1}\right), 4.51\left(\mathrm{~d}, 1 \mathrm{H}, J=14.3 \mathrm{~Hz}, \mathrm{H}_{3}\right), 2.23\left(\mathrm{~s}, 3 \mathrm{H}, \mathrm{CH}_{3}\right) ;{ }^{13} \mathrm{C}$ NMR $\left(\right.$ DMSO- $\left.d_{6}\right)$ : $\delta$ 9.4, 52.0, 54.7, 75.2, $103.9\left(\mathrm{dd},{ }^{2} J C F={ }^{2} J C F=25.8 \mathrm{~Hz}\right), 109.2,109.5,110.9\left(\mathrm{~d},{ }^{2} J C F=20.5 \mathrm{~Hz}\right), 118.2$, $118.3,121.0,124.3\left(\mathrm{dd},{ }^{2} J C F=12.9 \mathrm{~Hz},{ }^{4} J C F=3.3 \mathrm{~Hz}\right), 127.3,127.9,130.1\left(\mathrm{dd},{ }^{3} J C F={ }^{3} J C F=6.2 \mathrm{~Hz}\right)$, $137.2,145.0,150.6,159.1\left(\mathrm{dd},{ }^{1} J C F=246.5 \mathrm{~Hz},{ }^{3} J C F=12.4 \mathrm{~Hz}\right), 160.5\left(\mathrm{dd},{ }^{1} J C F=246.5 \mathrm{~Hz},{ }^{3} J C F=12.9\right.$ $\mathrm{Hz}$ ); MS m/z: $368\left(\mathrm{M}^{+}\right), 255,144$ (100), 82. Anal. Calcd. for $\mathrm{C}_{20} \mathrm{H}_{18} \mathrm{~F}_{2} \mathrm{~N}_{4} \mathrm{O}$ (368.38): C: 65.20; $\mathrm{H}: 4.89 ; \mathrm{N}$ : 15.20; found: C: $65.18 ; \mathrm{H}: 4.91 ; \mathrm{N}: 15.22 \%$.

2-(2,4-Dichlorophenyl)-3-(3-methyl-1H-indol-1-yl)-1-(1H-1,2,4-triazol-1-yl)propan-2-ol (11i). Red powder (24\% yield); $\mathrm{Rf}=0.65$ (EtOAc/hexane: 1/10); mp: $161-162{ }^{\circ} \mathrm{C} ; \mathrm{IR}(\mathrm{KBr}): v 3399(\mathrm{w}, \mathrm{OH}), 1586$, $1275 \mathrm{~cm}^{-1} ;{ }^{1} \mathrm{H}$ NMR (DMSO- $\left.d_{6}\right): \delta 8.31\left(\mathrm{~s}, 1 \mathrm{H}, \mathrm{H}_{3^{\prime \prime \prime}}\right), 7.77\left(\mathrm{~s}, 1 \mathrm{H}, \mathrm{H}_{5^{\prime \prime \prime}}\right), 7.62\left(\mathrm{~d}, 1 \mathrm{H}, J=2.1 \mathrm{~Hz}, \mathrm{H}_{3^{\prime}}\right), 7.46$ $\left(\mathrm{d}, 1 \mathrm{H}, J=7.5 \mathrm{~Hz}, \mathrm{H}_{7^{\prime \prime}}\right), 7.44\left(\mathrm{~d}, 1 \mathrm{H}, J=7.5 \mathrm{~Hz}, \mathrm{H}_{4^{\prime \prime}}\right), 7.42\left(\mathrm{~d}, 1 \mathrm{H}, J=8.9 \mathrm{~Hz}, \mathrm{H}_{6^{\prime}}\right), 7.25(\mathrm{dd}, 1 \mathrm{H}, J=8.9$ $\left.\mathrm{Hz}, J=2.1 \mathrm{~Hz}, \mathrm{H}_{5^{\prime}}\right), 7.13\left(\mathrm{dd}, 1 \mathrm{H}, J=J=7.5 \mathrm{~Hz}, \mathrm{H}_{5^{\prime \prime}}\right), 7.04\left(\mathrm{~s}, 1 \mathrm{H}, \mathrm{H}_{2^{\prime \prime}}\right), 7.01(\mathrm{dd}, 1 \mathrm{H}, J=J=7.5 \mathrm{~Hz}$, $\left.\mathrm{H}_{5^{\prime \prime}}\right), 6.33(\mathrm{~s}, 1 \mathrm{H}, \mathrm{OH}), 5.31\left(\mathrm{~d}, 1 \mathrm{H}, J=14.3 \mathrm{~Hz}, \mathrm{H}_{3}\right), 4.73\left(\mathrm{~s}, 2 \mathrm{H}, \mathrm{H}_{1}\right), 4.50\left(\mathrm{~d}, 1 \mathrm{H}, J=14.3 \mathrm{~Hz}, \mathrm{H}_{3}\right), 2.22(\mathrm{~s}$, $3 \mathrm{H}, \mathrm{CH}_{3}$ ); ${ }^{13} \mathrm{C}$ NMR (DMSO-d 6 ): $\delta$ 9.4, 50.7, 53.3, 76.7, 109.4, 109.9, 118.3 (2C), 121.2, 127.0, 127.4, 128.0, 129.9, 131.2, 131.4, 133.1, 137.0, 137.4, 145.1, 150.6; MS m/z: 400, 402, $404\left(\mathrm{M}^{+}\right), 255,144$ (100), 82. Anal. Calcd. for $\mathrm{C}_{20} \mathrm{H}_{18} \mathrm{Cl}_{2} \mathrm{~N}_{4} \mathrm{O}$ (401.29): C: 59.86; $\mathrm{H}: 4.49 ; \mathrm{N}: 13.95$; found: C: 59.83; H: 4.52; N: $13.98 \%$.

2-(2,4-Difluorophenyl)-3-(2,3-dimethyl-1H-indol-1-yl)-1-(1H-1,2,4-triazol-1-yl)propan-2-ol (11j). Red powder (22\% yield); $\mathrm{Rf}=0.16$ (EtOAc/hexane: $1 / 10) ; \mathrm{mp}: 102-103^{\circ} \mathrm{C} ; \mathrm{IR}(\mathrm{KBr}): v 3384(\mathrm{w}, \mathrm{OH}), 1614,1272$ $\mathrm{cm}^{-1} ;{ }^{1} \mathrm{H}$ NMR (DMSO-d $\left.d_{6}\right): \delta 8.38\left(\mathrm{~s}, 1 \mathrm{H}, \mathrm{H}_{3^{\prime \prime \prime}}\right), 7.79\left(\mathrm{~s}, 1 \mathrm{H}, \mathrm{H}_{5^{\prime \prime \prime}}\right), 7.20-7.31\left(\mathrm{~m}, 2 \mathrm{H}, \mathrm{H}_{3^{\prime}}, \mathrm{H}_{5^{\prime}}\right), 7.39(\mathrm{~d}, 1 \mathrm{H}$, $\left.J=6.4 \mathrm{~Hz}, \mathrm{H}_{4^{\prime \prime}}\right), 7.36\left(\mathrm{~d}, 1 \mathrm{H}, J=6.4 \mathrm{~Hz}, \mathrm{H}_{7^{\prime \prime}}\right), 7.09\left(\mathrm{dd}, 1 \mathrm{H}, J=J=6.4 \mathrm{~Hz}, \mathrm{H}_{6^{\prime \prime}}\right), 6.86-7.01\left(\mathrm{~m}, 2 \mathrm{H}, \mathrm{H}_{6^{\prime}}\right.$, $\left.\mathrm{H}_{5^{\prime \prime}}\right), 6.06(\mathrm{~s}, 1 \mathrm{H}, \mathrm{OH}), 4.96\left(\mathrm{~d}, 1 \mathrm{H}, J=14.5 \mathrm{~Hz}, \mathrm{H}_{3}\right), 4.60\left(\mathrm{~d}, 1 \mathrm{H}, J=14.5 \mathrm{~Hz}, \mathrm{H}_{1}\right), 4.55(\mathrm{~d}, 1 \mathrm{H}, J=14.5 \mathrm{~Hz}$, $\left.\mathrm{H}_{3}\right), 4.43\left(\mathrm{~d}, 1 \mathrm{H}, J=15.6 \mathrm{~Hz}, \mathrm{H}_{1}\right), 2.18(\mathrm{~s}, 6 \mathrm{H}) ;{ }^{13} \mathrm{C}$ NMR (DMSO- $\left.d_{6}\right): 8.8,10.2,49.9,54.8,75.6,104.1(\mathrm{dd}$, $\left.{ }^{2} J C F={ }^{2} J C F=25.7 \mathrm{~Hz}\right), 106.1,109.7,111.0\left(\mathrm{dd},{ }^{2} J C F=20.5 \mathrm{~Hz},{ }^{4} J C F=2.9 \mathrm{~Hz}\right), 117.3,118.5,120.2,124.9(\mathrm{dd}$, $\left.{ }^{3} J C F=9.1 \mathrm{~Hz},{ }^{3} J C F=12.9 \mathrm{~Hz}\right), 128.3,130.1\left(\mathrm{dd},{ }^{2} J C F=22.4 \mathrm{~Hz},{ }^{4} J C F=3.8 \mathrm{~Hz}\right), 133.8,137.2,145.2,150.6$, $159.3\left(\mathrm{dd},{ }^{1} J C F=254.6 \mathrm{~Hz},{ }^{3} J C F=11.4 \mathrm{~Hz}\right), 160.8\left(\mathrm{dd},{ }^{1} J C F=246.5 \mathrm{~Hz},{ }^{3} J C F=8.5 \mathrm{~Hz}\right) ; \mathrm{MS} \mathrm{m} / z: 382\left(\mathrm{M}^{+}\right)$, 269, 158 (100), 82. Anal. Calcd. for $\mathrm{C}_{21} \mathrm{H}_{20} \mathrm{~F}_{2} \mathrm{~N}_{4} \mathrm{O}$ (382.41): C: 65.95; $\mathrm{H}: 5.23 ; \mathrm{N}: 14.64$; found: C: 65.98; $\mathrm{H}$ : $5.25 ; \mathrm{N}: 14.62 \%$.

2-(2,4-Dichlorophenyl)-3-(2,3-dimethyl-1H-indol-1-yl)-1-(1H-1,2,4-triazol-1-yl)propan-2-ol (11k). White powder (15\% yield); $\mathrm{Rf}=0.17$ (EtOAc/hexane: $1 / 1) ; \mathrm{mp}: 123-124{ }^{\circ} \mathrm{C} ; \mathrm{IR}(\mathrm{KBr}): \vee 3429(\mathrm{w}, \mathrm{OH})$, 1584, $1273 \mathrm{~cm}^{-1}$; ${ }^{1} \mathrm{H}$ NMR (DMSO- $\left.d_{6}\right): \delta 8.39$ (s, $\left.1 \mathrm{H}, \mathrm{H}_{3^{\prime \prime \prime}}\right), 7.80\left(\mathrm{~s}, 1 \mathrm{H}, \mathrm{H}_{5^{\prime \prime \prime}}\right), 7.57(\mathrm{~d}, 1 \mathrm{H}, J=1.8 \mathrm{~Hz}$, $\left.\mathrm{H}_{3^{\prime}}\right), 7.51\left(\mathrm{~d}, 1 \mathrm{H}, J=7.9 \mathrm{~Hz}, \mathrm{H}_{4^{\prime \prime}}\right), 7.40\left(\mathrm{~d}, 1 \mathrm{H}, J=8.3 \mathrm{~Hz}, \mathrm{H}_{6^{\prime}}\right), 7.37\left(\mathrm{~d}, 1 \mathrm{H}, J=7.9 \mathrm{~Hz}, \mathrm{H}_{7^{\prime \prime}}\right), 7.27(\mathrm{dd}, 1 \mathrm{H}$, 
$\left.J=8.3 \mathrm{~Hz}, J=1.8 \mathrm{~Hz}, \mathrm{H}_{5^{\prime}}\right), 7.11\left(\mathrm{dd}, 1 \mathrm{H}, J=J=7.9 \mathrm{~Hz}, \mathrm{H}_{6^{\prime \prime}}\right), 7.00\left(\mathrm{dd}, 1 \mathrm{H}, J=J=7.9 \mathrm{~Hz}, \mathrm{H}_{5^{\prime \prime}}\right), 6.03$ $(\mathrm{s}, 1 \mathrm{H}, \mathrm{OH}), 5.39\left(\mathrm{~d}, 1 \mathrm{H}, J=14.3 \mathrm{~Hz}, \mathrm{H}_{3}\right), 4.90\left(\mathrm{~d}, 1 \mathrm{H}, J=15.3 \mathrm{~Hz}, \mathrm{H}_{1}\right), 4.66\left(\mathrm{~d}, 1 \mathrm{H}, J=14.3 \mathrm{~Hz}, \mathrm{H}_{3}\right), 4.51$ $\left(\mathrm{d}, 1 \mathrm{H}, J=15.3 \mathrm{~Hz}, \mathrm{H}_{1}\right), 2.21(\mathrm{~s}, 6 \mathrm{H}) ;{ }^{13} \mathrm{C}$ NMR $\left(\mathrm{DMSO}-d_{6}\right): 10.3,13.9,48.2,53.4,76.7,106.1,109.4,117.3$, 118.5, 120.1, 127.2, 127.6, 130.0, 131.1, 131.2, 133.2, 137.3, 137.8, 140.4, 146.2, 150.6; MS m/z: 414, 416, 418 $\left(\mathrm{M}^{+}\right), 269,158$ (100), 82. Anal. Calcd. for $\mathrm{C}_{21} \mathrm{H}_{20} \mathrm{Cl}_{2} \mathrm{~N}_{4} \mathrm{O}$ (415.32): C: 60.73; $\mathrm{H}: 4.82 ; \mathrm{N}: 13.48$; found: $\mathrm{C}$ : 60.69; H: 4.79; N: $13.52 \%$.

\subsection{Synthesis of Compounds $\mathbf{1 1 1}$ and $\mathbf{1 1 m}$ (Route 2)}

\subsubsection{Procedure for the $\mathrm{N}-1$ and $\mathrm{N}$-2-alkylation of $1 \mathrm{H}-1,2,3$-Triazole}

1-(2,4-Dichlorophenyl)-2-(1H-1,2,3-triazol-1-yl)ethanone (9g) and 1-(2,4-dichlorophenyl)-2-(2H1,2,3-triazol-2-yl)ethan-1-one (9h) were synthesized according to methods a and $\mathrm{b}$.

Method a: To a solution of 2-chloro-2', $4^{\prime}$-dichloroacetophenone $(2.50 \mathrm{~g}, 11.19 \mathrm{mmol})$ in acetonitrile (40 mL) $1 \mathrm{H}-1,2,3$-triazole $(1.55 \mathrm{~g}, 22.37 \mathrm{mmol})$ and $\mathrm{K}_{2} \mathrm{CO}_{3}(3.09 \mathrm{~g}, 22.37 \mathrm{mmol})$ were added. The reaction mixture was irradiated for $50 \mathrm{~min}$ in a microwave oven (Discover, CEM) and programmed to obtain a temperature of $85^{\circ} \mathrm{C}$ with a maximum power output of $50 \mathrm{~W}$. After cooling, the mixture was filtered and the volatile fraction was evaporated under reduced pressure. The residue was diluted with $\mathrm{H}_{2} \mathrm{O}$ $(40 \mathrm{~mL})$ and extracted with EtOAc $(3 \times 80 \mathrm{~mL})$, then the organic layer was washed with brine $(80 \mathrm{~mL})$, dried over anhydrous sodium sulfate, and the volatile fraction was evaporated under reduced pressure. ${ }^{1} \mathrm{H}$ NMR (DMSO- $d_{6}$ ) of the residue gave a ratio $49 / 51$ of compounds $9 \mathrm{~g} / 9 \mathbf{h}$. The residue was purified by silica gel column chromatography (dichloromethane).

1-(2,4-Dichlorophenyl)-2-(1H-1,2,3-triazol-1-yl)ethanone (9g). White powder (49\% yield); $\mathrm{Rf}=0.06$ (dichloromethane); mp: 118-120 ${ }^{\circ} \mathrm{C}$; IR (KBr): $v 1717$ (s, C=O), 1585, $1215 \mathrm{~cm}^{-1} ;{ }^{1} \mathrm{H}$ NMR (DMSO- $\left.d_{6}\right)$ : $\delta 8.16\left(\mathrm{~s}, 1 \mathrm{H}, \mathrm{H}_{5^{\prime \prime}}\right) ; 8.05\left(\mathrm{~d}, 1 \mathrm{H}, J=8.5 \mathrm{~Hz}, \mathrm{H}_{6^{\prime}}\right) ; 7.88\left(\mathrm{~d}, 1 \mathrm{H}, J=2.1 \mathrm{~Hz}, \mathrm{H}_{3^{\prime}}\right) ; 7.84\left(\mathrm{~s}, 1 \mathrm{H}, \mathrm{H}_{4^{\prime \prime}}\right) ; 7.70(\mathrm{dd}$, $\left.2 \mathrm{H}, J=8.5 \mathrm{~Hz}, J=2.1 \mathrm{~Hz}, \mathrm{H}_{5^{\prime}}\right) ; 6.11\left(\mathrm{~s}, 2 \mathrm{H}, \mathrm{CH}_{2}\right) ;{ }^{13} \mathrm{C} \mathrm{NMR}\left(\mathrm{DMSO}-d_{6}\right): 57.5,126.4,127.7,130.6,131.5$, 132.1, 133.3, 133.4, 137.5, 192.9.

1-(2,4-Dichlorophenyl)-2-(2H-1,2,3-triazol-2-yl)ethan-1-one (9h). White powder (50\%); $\mathrm{Rf}=0.29$ (dichloromethane); mp: 100-101 ${ }^{\circ} \mathrm{C}$; IR (KBr): $v 1717$ (s, C=O), 1580, $1204 \mathrm{~cm}^{-1} ;{ }^{1} \mathrm{H}$ NMR (DMSO- $d_{6}$ ): $\delta 7.99\left(\mathrm{~d}, 1 \mathrm{H}, J=8.5 \mathrm{~Hz}, \mathrm{H}_{6^{\prime}}\right) ; 7.91\left(\mathrm{~s}, 2 \mathrm{H}, \mathrm{H}_{3^{\prime \prime}}, \mathrm{H}_{4^{\prime \prime}}\right) ; 7.84\left(\mathrm{~d}, 1 \mathrm{H}, \mathrm{J}=2.1 \mathrm{~Hz}, \mathrm{H}_{3^{\prime}}\right) ; 7.65(\mathrm{dd}, 1 \mathrm{H}, J=8.5$ $\left.\mathrm{Hz}, J=2.1 \mathrm{~Hz}, \mathrm{H}_{5^{\prime}}\right) ; 6.14\left(\mathrm{~s}, 2 \mathrm{H}, \mathrm{CH}_{2}\right) ;{ }^{13} \mathrm{C} \mathrm{NMR}\left(\mathrm{DMSO}-d_{6}\right): 62.1,127.6,130.5,131.3,132.0,133.6,135.3$ (2C), 137.3, 193.5.

Method b: To a solution of 2-chloro-2', $4^{\prime}$-dichloroacetophenone $(2.50 \mathrm{~g}, 11.19 \mathrm{mmol})$ in acetonitrile ( $40 \mathrm{~mL}) 1 \mathrm{H}-1,2,3$-triazole $(1.55 \mathrm{~g}, 22.37 \mathrm{mmol})$ and $\mathrm{K}_{2} \mathrm{CO}_{3}(3.09 \mathrm{~g}$, $22.37 \mathrm{mmol})$ were added. The reaction mixture was heated at $85^{\circ} \mathrm{C}$ for $8 \mathrm{~h}$. After cooling, the mixture was filtered and the volatile fraction was evaporated under reduced pressure. The residue was diluted with $\mathrm{H}_{2} \mathrm{O}(40 \mathrm{~mL})$ and extracted with EtOAc $(3 \times 80 \mathrm{~mL})$, then the organic layer was washed with brine $(80 \mathrm{~mL})$, dried over anhydrous sodium sulfate, and the volatile fraction was evaporated under reduced pressure. ${ }^{1} \mathrm{H}$ NMR $\left(\mathrm{DMSO}-d_{6}\right)$ of the residue gave a ratio $61 / 39$ of compounds $9 \mathrm{~g} / 9 \mathbf{h}$.

\subsubsection{General Procedure for the Synthesis of Oxiranes $10 \mathrm{~g}$ and $10 \mathrm{~h}$}

A procedure [27] similar to that for obtaining 10a was used to prepare compounds $10 \mathrm{~g}$ and $\mathbf{1 0 h}$.

2-(2,4-Dichlorophenyl)-3-(1H-1,2,3-triazol-1-yl)-1,2-epoxypropane (10g). Orange oil (99\% yield); $\mathrm{Rf}=0.65(\mathrm{EtOH} /$ dichloromethane: $1 / 10) ; \mathrm{IR}(\mathrm{NaCl}): v 1583,1276 \mathrm{~cm}^{-1} ;{ }^{1} \mathrm{H}$ NMR $\left(\mathrm{DMSO}-d_{6}\right): \delta 8.05$ $\left(\mathrm{s}, 1 \mathrm{H}, \mathrm{H}_{5^{\prime \prime}}\right) ; 7.73\left(\mathrm{~s}, 1 \mathrm{H}, \mathrm{H}_{4^{\prime \prime}}\right) ; 7.72\left(\mathrm{~d}, 1 \mathrm{H}, J=2.1 \mathrm{~Hz}, \mathrm{H}_{3^{\prime}}\right) ; 7.37\left(\mathrm{dd}, 1 \mathrm{H}, J=8.2 \mathrm{~Hz}, J=2.1 \mathrm{~Hz}, \mathrm{H}_{5^{\prime}}\right) ; 7.09$ $\left(\mathrm{d}, 1 \mathrm{H}, J=8.2 \mathrm{~Hz}, \mathrm{H}_{6^{\prime}}\right) ; 5.12\left(\mathrm{~d}, 1 \mathrm{H}, J=14.7 \mathrm{~Hz}, \mathrm{H}_{3}\right) ; 4.77\left(\mathrm{~d}, 1 \mathrm{H}, J=14.7 \mathrm{~Hz}, \mathrm{H}_{3}\right) ; 3.20(\mathrm{~d}, 1 \mathrm{H}, J=4.9$ $\left.\mathrm{Hz}, \mathrm{H}_{1}\right) ; 3.00\left(\mathrm{~d}, 1 \mathrm{H}, J=4.9 \mathrm{~Hz}, \mathrm{H}_{1}\right) ;{ }^{13} \mathrm{C}$ NMR (DMSO-d $\left.{ }_{6}\right): 51.9,52.9,58.5,125.8,127.3,128.7,130.8$, 133.1, 133.4, 133.5, 134.0.

2-(2,4-Dichlorophenyl)-3-(2H-1,2,3-triazol-2-yl)-1,2-epoxypropane (10h). Orange oil (86\% yield); $\mathrm{Rf}=0.74(\mathrm{EtOH} /$ dichloromethane: $1 / 10) ; \mathrm{IR}(\mathrm{NaCl}): v 1584,1256 \mathrm{~cm}^{-1} ;{ }^{1} \mathrm{H}$ NMR (DMSO- $\left.d_{6}\right): \delta 7.76(\mathrm{~s}$, $\left.2 \mathrm{H}, \mathrm{H}_{3^{\prime \prime}}, \mathrm{H}_{4^{\prime \prime}}\right) ; 7.67\left(\mathrm{~d}, 1 \mathrm{H}, J=2.1 \mathrm{~Hz}, \mathrm{H}_{3^{\prime}}\right) ; 7.33\left(\mathrm{dd}, 1 \mathrm{H}, J=8.2 \mathrm{~Hz}, J=2.1 \mathrm{~Hz}, \mathrm{H}_{5^{\prime}}\right) ; 7.08(\mathrm{~d}, 1 \mathrm{H}, J=8.2$ 
$\left.\mathrm{Hz}, \mathrm{H}_{6^{\prime}}\right) ; 5.15\left(\mathrm{~d}, 1 \mathrm{H}, J=14.7 \mathrm{~Hz}, \mathrm{H}_{3}\right) ; 4.78\left(\mathrm{~d}, 1 \mathrm{H}, J=14.7 \mathrm{~Hz}, \mathrm{H}_{3}\right) ; 3.25\left(\mathrm{~d}, 1 \mathrm{H}, J=4.6 \mathrm{~Hz}, \mathrm{H}_{1}\right) ; 2.98$ $\left(\mathrm{d}, 1 \mathrm{H}, J=4.6 \mathrm{~Hz}, \mathrm{H}_{1}\right) ;{ }^{13} \mathrm{C}$ NMR (DMSO- $\left.d_{6}\right): 51.4,58.0,62.1,127.2,128.5,130.9,133.8(2 \mathrm{C}), 134.8(3 \mathrm{C})$.

\subsubsection{General Procedure for the Sysnthesis of Triazole Derivatives 111 and $11 \mathrm{~m}$}

A procedure similar to 11a was used to prepare compounds 111 and $11 \mathrm{~m}$.

2-(2,4-Dichlorophenyl)-3-(1H-indol-1-yl)-1-(1H-1,2,3-triazol-1-yl)propan-2-ol (111). White powder (52\% yield); $\mathrm{Rf}=0.11$ (EtOAc/hexane: 1/1); $\mathrm{mp}: 210-211^{\circ} \mathrm{C}$; $\mathrm{IR}(\mathrm{KBr}): \vee 3166(\mathrm{w}, \mathrm{OH}), 1585,1214 \mathrm{~cm}^{-1}$; ${ }^{1} \mathrm{H}$ NMR (DMSO- $\left.d_{6}\right): \delta 7.87\left(\mathrm{~s}, 1 \mathrm{H}, \mathrm{H}_{5^{\prime \prime \prime}}\right), 7.64\left(\mathrm{~d}, 1 \mathrm{H}, \mathrm{J}=2.1 \mathrm{~Hz}, \mathrm{H}_{3^{\prime}}\right), 7.58\left(\mathrm{~s}, 1 \mathrm{H}, \mathrm{H}_{4^{\prime \prime \prime}}\right), 7.53(\mathrm{~d}, 1 \mathrm{H}$, $\left.J=7.0 \mathrm{~Hz}, \mathrm{H}_{4^{\prime \prime}}\right), 7.51\left(\mathrm{~d}, 1 \mathrm{H}, J=7.0 \mathrm{~Hz}, \mathrm{H}_{7^{\prime \prime}}\right), 7.36\left(\mathrm{~d}, 1 \mathrm{H}, J=8.9 \mathrm{~Hz}, \mathrm{H}_{6^{\prime}}\right), 7.23\left(\mathrm{~d}, 1 \mathrm{H}, J=2.8 \mathrm{~Hz}, \mathrm{H}_{2^{\prime \prime}}\right)$, $7.21\left(\mathrm{dd}, 1 \mathrm{H}, J=8.9 \mathrm{~Hz}, J=2.1 \mathrm{~Hz}, \mathrm{H}_{5^{\prime}}\right), 7.14\left(\mathrm{dd}, 1 \mathrm{H}, J=J=7.0 \mathrm{~Hz}, \mathrm{H}_{6^{\prime \prime}}\right), 7.01(\mathrm{dd}, 1 \mathrm{H}, J=J=7.0 \mathrm{~Hz}$, $\left.\mathrm{H}_{5^{\prime \prime}}\right), 6.47(\mathrm{~s}, 1 \mathrm{H}, \mathrm{OH}), 6.41\left(\mathrm{~d}, 1 \mathrm{H}, J=2.8 \mathrm{~Hz}, \mathrm{H}_{3^{\prime \prime}}\right), 5.61\left(\mathrm{~d}, 1 \mathrm{H}, J=13.7 \mathrm{~Hz}, \mathrm{H}_{3}\right), 4.90(\mathrm{~d}, 1 \mathrm{H}, J=14.4$ $\left.\mathrm{Hz}, \mathrm{H}_{1}\right), 4.83\left(\mathrm{~d}, 1 \mathrm{H}, J=14.4 \mathrm{~Hz}, \mathrm{H}_{1}\right), 4.65\left(\mathrm{~d}, 1 \mathrm{H}, J=13.7 \mathrm{~Hz}, \mathrm{H}_{3}\right) ;{ }^{13} \mathrm{C}$ NMR (DMSO- $\left.d_{6}\right): 50.8,53.7$, 76.8, 101.2, 110.1, 118.9, 120.1, 121.1, 125.8, 126.9, 127.6, 129.6, 129.9, 131.2 (2C), 132.6, 133.1, 136.4, 137.0; MS m/z: 386, 388, $390\left(\mathrm{M}^{+}\right), 241,130$ (100), 82. Anal. Calcd. for $\mathrm{C}_{19} \mathrm{H}_{16} \mathrm{Cl}_{2} \mathrm{~N}_{4} \mathrm{O}$ (387.26): C: 58.92; $\mathrm{H}$ : 4.13; N: 14.46; found: C: 58.88; H: 4.10; N: 14.43\%.

2-(2,4-Dichlorophenyl)-3-(1H-indol-1-yl)-1-(2H-1,2,3-triazol-2-yl)propan-2-ol (11m). White powder (56\% yield); $\mathrm{Rf}=0.59$ (EtOAc/hexane: $1 / 1) ; \mathrm{mp}: 159-161{ }^{\circ} \mathrm{C} ; \mathrm{IR}(\mathrm{KBr}): v 3434(\mathrm{w}, \mathrm{OH}), 1589,1215 \mathrm{~cm}^{-1} ;{ }^{1} \mathrm{H}$ NMR (DMSO- $\left.d_{6}\right): \delta 7.67\left(\mathrm{~s}, 2 \mathrm{H}, \mathrm{H}_{3^{\prime \prime \prime}}, \mathrm{H}_{4^{\prime \prime \prime}}\right), 7.61\left(\mathrm{~d}, 1 \mathrm{H}, \mathrm{J}=2.1 \mathrm{~Hz}, \mathrm{H}_{3^{\prime}}\right), 7.53\left(\mathrm{~d}, 1 \mathrm{H}, J=7.6 \mathrm{~Hz}, \mathrm{H}_{4^{\prime \prime}}\right), 7.48$ $\left(\mathrm{d}, 1 \mathrm{H}, J=7.6 \mathrm{~Hz}, \mathrm{H}_{7^{\prime \prime}}\right), 7.32\left(\mathrm{~d}, 1 \mathrm{H}, J=8.5 \mathrm{~Hz}, \mathrm{H}_{6^{\prime}}\right), 7.20\left(\mathrm{~d}, 1 \mathrm{H}, J=3.1 \mathrm{~Hz}, \mathrm{H}_{2^{\prime \prime}}\right), 7.17(\mathrm{dd}, 1 \mathrm{H}, J=8.5 \mathrm{~Hz}$, $\left.J=2.1 \mathrm{~Hz}, \mathrm{H}_{5^{\prime}}\right), 7.09\left(\mathrm{dd}, 1 \mathrm{H}, J=J=7.6 \mathrm{~Hz}, \mathrm{H}_{6^{\prime \prime}}\right), 6.98\left(\mathrm{dd}, 1 \mathrm{H}, J=J=7.6 \mathrm{~Hz}, \mathrm{H}_{5^{\prime \prime}}\right), 6.36(\mathrm{~d}, 1 \mathrm{H}, J=3.1 \mathrm{~Hz}$, $\left.\mathrm{H}_{3^{\prime \prime}}\right), 6.28(\mathrm{~s}, 1 \mathrm{H}, \mathrm{OH}), 5.56\left(\mathrm{~d}, 1 \mathrm{H}, J=14.0 \mathrm{~Hz}, \mathrm{H}_{3}\right), 4.99\left(\mathrm{~d}, 1 \mathrm{H}, J=15.0 \mathrm{~Hz}, \mathrm{H}_{1}\right), 4.83\left(\mathrm{~d}, 1 \mathrm{H}, J=14.0 \mathrm{~Hz}, \mathrm{H}_{3}\right)$, $4.72\left(\mathrm{~d}, 1 \mathrm{H}, J=15.0 \mathrm{~Hz}, \mathrm{H}_{1}\right) ;{ }^{13} \mathrm{C}$ NMR (DMSO- $\left.d_{6}\right): 50.8,58.4,77.1,101.0,110.2,118.8,120.1,120.9,126.8$, 127.5, 129.5, 129.7, 131.3, 131.5, 132.9, 134.2 (2C); 137.0 (2C); MS m/z: 386, 388, $390\left(\mathrm{M}^{+}\right), 241,130$ (100), 82. Anal. Calcd. for $\mathrm{C}_{19} \mathrm{H}_{16} \mathrm{Cl}_{2} \mathrm{~N}_{4} \mathrm{O}$ (387.26): C: $58.92 ; \mathrm{H}: 4.13 ; \mathrm{N}: 14.46$; found: C: $58.90 ; \mathrm{H}: 4.15 ; \mathrm{N}: 14.41 \%$.

\subsection{Chiral HPLC Chromatography}

The chromatography system consisted of SpectraSystem (Thermo Electron S.A., Waltham, MA, USA) P1000-010XR2 isocratic pump and a dual wavelength SpectraSystem UV2000 detector. T data acquisition system was performed with an IBM PC/computer using Azur 3.0 (Datalys, Saint-Martin d'Héres, France) as chromatography sofware. Chromatography was performed on the Chiralcel OD-H column $(250 \times 4.6 \mathrm{~mm}$, Daicel Chemical Industries Ltd, Tokyo, Japan) packed with $5 \mu \mathrm{m}$ silica gel coated by cellulose tris(3,5-dimethylphenylcarbamate). A Rheodyne 9125 injector with a $20 \mu \mathrm{L}$ sample loop was used. The mobile phases used were: (A) Acetonitrile, 100; (B) acetonitrile/diethylamine, 100:0.1 (v/v); (C) ethanol/diethylamine, 100:0.1 (v/v); (D) methanol/diethylamine, 100:0.1 (v/v); (E) n-hexane/ethanol/diethylamine, 60:40:0.1 (v/v/v); (F) n-hexane/methanol/ethanol/diethylamine, 75:15:10:0.1 $(v / v / v / v)$. Solvents were of HPLC quality (Carlo Erba, Val de Reuil, France). The flow rate was $1.1 \mathrm{~mL} / \mathrm{min}$ and the injection volume was $20 \mu \mathrm{L}$. The detection wavelength was $250 \mathrm{~nm}$. The column temperature was at $25-30{ }^{\circ} \mathrm{C}$. The sample concentration was $10 \mu \mathrm{g} / \mathrm{mL}$ in mobile phase. This method was used to separate the enantiomers of compound $8 \mathrm{~g}$.

\subsection{X-ray Crystallography Studies}

The structure of compounds (+)-8g and (-)-8g was established by X-ray crystallography (Figures 2 and 3) [44]. A colorless single crystal $\left(0.25 \times 0.10 \times 0.05 \mathrm{~mm}^{3}\right)$ of $(+)-8 \mathrm{~g}$ was obtained by slow evaporation from methanol/chloroform (30:70, $v / v)$ solution: Monoclinic, space group P21, $a=6.707(2)$ $\AA, b=32.174(4) \AA, c=10.080(2) \AA, \alpha=90.0^{\circ}, \beta=109.40(2)^{\circ}, \gamma=90.0^{\circ}, V=2051.7(8) \AA^{3}, Z=2$, $\delta($ calcd $)=1.254 \mathrm{Mg} \cdot \mathrm{m}^{-3}, \mathrm{FW}=774.52$ for $\mathrm{C}_{38} \mathrm{H}_{32} \mathrm{Cl}_{4} \mathrm{~N}_{8} \mathrm{O}_{2}, F(000)=800$. A colorless single crystal $\left(0.25 \times 0.10 \times 0.07 \mathrm{~mm}^{3}\right)$ of $(-)-8 \mathrm{~g}$ was obtained by slow evaporation from methanol/chloroform (30:70, v/v) solution: Monoclinic, space group P21, $a=6.681(3) \AA, b=32.142(4) \AA, c=10.111(4) \AA$, $\alpha=90.0^{\circ}, \beta=109.40(2)^{\circ}, \gamma=90.0^{\circ}, V=2048.0(13) \AA^{3}, Z=2, \delta($ calcd $)=1.256 \mathrm{Mg} \cdot \mathrm{m}^{-3}, \mathrm{FW}=774.52$ for $\mathrm{C}_{38} \mathrm{H}_{32} \mathrm{Cl}_{4} \mathrm{~N}_{8} \mathrm{O}_{2}, F(000)=800$. The unit cell dimensions were determined using the least-squares fit from 
25 reflections $\left(25^{\circ}<\theta<35^{\circ}\right)$. Intensities were collected with an Enraf-Nonius CAD-4 diffractometer using the $\mathrm{CuK} \alpha$ radiation and a graphite monochromator up to $\theta=55^{\circ}$. No intensity variation of 2 standard reflections monitored every $90 \mathrm{~min}$ was observed. The data were corrected for Lorentz and polarization effects and for empirical absorption correction [45]. The structure was solved by direct methods Shelx 86 [46] and refined using Shelx 93 [47] suite of programs.

\subsection{Biological Assays}

\subsubsection{Anti-Candida In Vitro Assay}

Test fungal strains were obtained from the American Type Culture Collection (ATCC) or were clinical isolates from the Laboratory of Parasitology and Medical Mycology, Centre Hospitalier Universitaire ( $\mathrm{CHU})$ of Nantes. The strains were maintained on Sabouraud agar slants and were subcultured $24 \mathrm{~h}$ before used. The activity of the target compounds $8 \mathbf{a}-\mathbf{g}$ and $\mathbf{1 1 a}-\mathbf{m}$ was determined by the method previously described [48]. Briefly, molecules were diluted in RPMI 1640 medium supplemented with $0.165 \mathrm{M}$ morpholinopropanesulphonic acid (Sigma-Aldrich, Saint-Quentin Fallavier, France), 2\% glucose, and antibiotics. Candida suspensions were prepared in RPMI 1640 medium (Sigma-Aldrich, Saint-Quentin Fallavier, France) adjusted to give a final concentration of $10^{3}$ cells/mL, and a 96-well microplate (Nunc, D. Dutscher, Brumath, France) was seeded with $100 \mu \mathrm{L}$. Each concentration of molecules $(100 \mu \mathrm{L})$ to be tested was added (in triplicate) and plates were incubated at $37^{\circ} \mathrm{C}$ for $24 \mathrm{~h}$. The cellular viability was evaluated on the Fluorolite 1000 (Dynatech, France) with an excitation at $550 \mathrm{~nm}$ and an emission at $590 \mathrm{~nm}$ after a $4 \mathrm{~h}$ incubation with $10 \mu \mathrm{L}$ of Alamar Blue ${ }^{\circledR}$. The minimal inhibitory concentration (MIC) is the concentration that inhibited $80 \%$ of the cell growth and was determined by linear regression analysis. MIC was expressed as the mean of the triplicate values. KTC and FLC were used as standards.

\subsubsection{MRC5 Toxicity Assay}

The cytotoxicity of compounds was studied with human fibroblast (MRC5). Cells were grown in RPMI 1640 medium (Sigma-Aldrich, Saint-Quentin Fallavier, France) supplemented with 10\% fetal bovin serum (Sigma-Aldrich). Drugs were tested at three concentrations (100, 10, and $1 \mu \mathrm{M})$ in triplicate. After a 96-h incubation time, cytotoxicity was measured on the Fluorolite 1000 (Dynatech, Guyancourt, France) after a 4-h incubation time with Uptiblue ${ }^{\circledR}$ (Interchim, Montluçon, France). Inhibitory concentration 50 is a mean of triplicate values. A toxicity index was determined as follow: $\mathrm{IC}_{50}$ against MRC5/Geometric mean of the MICs against Candida spp. [28].

\subsubsection{In Vitro Inhibition of Aromatase}

The assay was performed according to previously described methods [49-51] by monitoring the enzyme activity by measuring the ${ }^{3} \mathrm{H}_{2} \mathrm{O}$ formed from $\left[1 \beta_{-}{ }^{3} \mathrm{H}\right]$ androstenedione during aromatization. In brief, the reaction mixture, containing $\left[1 \beta-{ }^{3} \mathrm{H}\right]$ androstenedione $(0.08 \mu \mathrm{Ci}, 15 \mathrm{nM})$, unlabeled androstenedione $(485 \mathrm{nM})$, the NADPH-generating system $(2 \mathrm{mM})$, the inhibitor $(0-100 \mu \mathrm{M})$, and phosphate buffer $(0.05 \mathrm{M}, \mathrm{pH} 7.4)$, was preincubated for $5 \mathrm{~min}$ at $30^{\circ} \mathrm{C}$. Microsomal protein $(0.1 \mathrm{mg})$ was added to start the reaction. After incubation of $15 \mathrm{~min}$ at $30^{\circ} \mathrm{C}$, the reaction was stopped by adding $200 \mu \mathrm{L}$ of a cold $\mathrm{HgCl}_{2}$ solution $(1 \mathrm{mM})$. After the addition of $200 \mu \mathrm{L}$ of an aqueous dextran-coated charcoal (DCC) suspension ( $2 \%$ ), the vials were shaken then centrifuged to separate the charcoal-absorbed steroids. Aliquots of the supernatant were assayed for ${ }^{3} \mathrm{H}_{2} \mathrm{O}$ by counting in a scintillation mixture using a LKB-Wallac $\beta$-counter.

\subsubsection{In Vitro Inhibition of $17 \alpha$-Hydroxylase/17,20-Lyase}

The assay was performed similar to described methods [29,52]. In summary, the reaction mixture containing progesterone $(1.25 \mathrm{mM}), \mathrm{NADPH}(125 \mathrm{nmol})$, the inhibitor, and phosphate buffer ( $\mathrm{pH}$ 7.4) was preincubated for $5 \mathrm{~min}$ at $32{ }^{\circ} \mathrm{C}$. Microsomal protein was added to start the reaction. 
After incubation for $20 \mathrm{~min}$ at $32^{\circ} \mathrm{C}$, the reaction was stopped by adding $50 \mu \mathrm{L}$ of $1 \mathrm{M}$ aqueous $\mathrm{HCl}$ solution. After the addition of $1 \mathrm{~mL}$ EtOAc, the vials were shaken then centrifuged. The organic phase was removed, vortexed with phosphate buffer $(250 \mu \mathrm{L}), 1 \mathrm{M}$ aqueous $\mathrm{HCl}(50 \mu \mathrm{L})$, and then dried. Aliquots of $25 \mu \mathrm{L}$ methanol, containing $250 \mathrm{pmol}$ of fluorocortisol acetate as internal standard, were added to the extracts. The samples $(20 \mu \mathrm{L})$ were submitted to HPLC (RP-8 column, methanol/water $1: 1, v / v)$ and measured using UV $(240 \mathrm{~nm})$. For compounds causing an inhibition over $80 \%, \mathrm{IC}_{50}$ values were determined.

3.7.5. MCF-7 Cell Culture and In Vitro Assay for Inhibition of Metabolism of All-trans Retinoic Acid (ATRA)

Human MCF-7 breast cancer cells were cultured in phenol red-free RPMI 1640 medium supplemented with 5\% (v/v) charcoal free fetal calf serum, antibiotics (penicillin and streptomycin), and fungizone at the same concentration of $10 \mathrm{iU} / \mathrm{mL}$ (all reagents from Gibco Europe Ltd., Scotland, $\mathrm{UK})$. Cells were grown in a humidified incubator $\left(5 \% \mathrm{CO}_{2}, 95 \%\right.$ air $)$ at $37{ }^{\circ} \mathrm{C}$.

$\left[11,12-{ }^{3} \mathrm{H}\right]$ All-trans-retinoic acid $(37 \mathrm{MBq} / \mathrm{mL})$ was purchased from PerkinElmer Life Science Ltd. (USA). All-trans retinoic acid, NADPH, butylated hydroxyanisole, and KTC were obtained from Sigma-Aldrich (Gillingham, UK). Liarozole was a gift from Stiefel Laboratories, High Wycombe, UK. MCF-7 cells were seeded in 12-well cell culture plates (Cornings Inc., New York, USA) at $2.5 \times 10^{5}$ cells per well in a total volume of $1.5 \mathrm{~mL}$. Cells were allowed to adhere to the well for $24 \mathrm{~h}$. After $24 \mathrm{~h}$, the medium from each well was removed, washed once with phosphate buffer saline (PBS), and replaced by fresh medium plus $10 \mu \mathrm{L}$ inhibitor/solvent (acetonitrile) and $10 \mu \mathrm{L}$ of ATRA (to give a final concentration of $1 \times 10^{-7} \mathrm{M}$ ATRA and $0.1 \mu \mathrm{Ci}\left[11,12-{ }^{3} \mathrm{H}\right]$ all-trans-retinoic acid). The plates were foil wrapped and incubated at $37^{\circ} \mathrm{C}$ for $9 \mathrm{~h}$. Each treatment was performed in duplicate. The incubation was stopped by addition of $1 \%$ acetic acid $(100 \mu \mathrm{L} /$ well $)$, the medium was removed into separate glass tubes. Distilled water $(200 \mu \mathrm{L})$ was added to each well and the cells scrapped off and the contents added to the appropriate glass tube. This procedure was repeated with a further $400 \mu \mathrm{L}$ water but without scraping. Ethyl acetate containing $0.05 \%(w / v)$ butylated hydroxyanisole $(2 \times 2 \mathrm{~mL})$ was added to each tube. After vortexing for $15 \mathrm{~s}$, the tubes were spun down at $3000 \mathrm{rpm}$ for $15 \mathrm{~min}$. The organic layer was then evaporated using a Christ centrifuge connected to a vacuum pump and a multitrap at $-80^{\circ} \mathrm{C}$.

The HPLC system was equipped with a high-pressure pump (Milton-Roy pump, Stone, UK), injector with a $50 \mu \mathrm{L}$ loop connected to a beta-RAM radioactivity detector, connected to a Compaq ${ }^{\mathrm{TM}}$ computer running Laura ${ }^{\circledR}$ data acquisition and analysis software. This enabled online detection and quantification of radioactive peaks. The $10 \mu \mathrm{M} \mathrm{C}_{18} \mu$ Bondapak $^{\mathrm{TM}} 3.9 \times 300 \mathrm{~mm}$ HPLC column (Waters, UK) was used for the all-trans retinoic acid metabolism studies. The HPLC column operating at an ambient temperature was used to separate the metabolites, which were eluted with acetonitrile/ $1 \%$ ammonium acetate in water/acetic acid $(75: 25: 0.1, v / v / v)$ at a flow rate of $1.9 \mathrm{~mL} / \mathrm{min}$. The Ecoscint ${ }^{\mathrm{TM}}$ was used as the flow scintillation fluid.

The separated $\left[{ }^{3} \mathrm{H}\right]$-metabolites were quantitatively calculated from the areas under the curves. Using a control with acetonitrile instead of inhibitor, these results were expressed as the "percentage inhibition relative to control" $=100[$ (metabolites (control)-metabolites (inhibitor)/(metabolites control)]\%. KTC and liarozole were used as standards [53].

\subsubsection{In Vitro Inhibition of CYP11B1 and CYP11B2}

For the CYP11B1 assay, 11-deoxycortisol (RSS) was used as substrate, whereas 11-deoxycorticosterone (DOC) was used for the CYP11B2 assay. These non-radioactive steroids were purchased from Sima (Deisenhofen, Germany). Radioactive steroids were obtained from Amersham Pharmacia Biotech (Freiburg, Germany). Two Schizosaccharomyces pombe strains were used, SZ1 expressing CYP11B1 and MB164 expressing CYP11B2. The assays were performed as described previously by Bureik et al. [54]. Exponentially growing fission yeast cells were cultivated by shaking and with good aeration at $30{ }^{\circ} \mathrm{C}$ in $500 \mu \mathrm{L}$ Edinburgh Minimal Medium Glutamate (EMMG) containing supplements as required. Inhibitors were dissolved in ethanol 
at different concentrations, and equal volumes of ethanolic solutions were used in all cases (including controls). Final concentrations of inhibitors ranged from $100 \mathrm{nM}$ to $5 \mu \mathrm{M}$. Cells were preincubated with the respective inhibitor solutions for $15 \mathrm{~min}$ prior to the addition of steroid substrates (100 $\mathrm{nM}$ DOC or $100 \mathrm{nM}$ RSS, respectively). For detection of steroids, $1 \%$ of the total substrate amount was radioactively labeled as $\left[{ }^{3} \mathrm{H}\right] \mathrm{RSS},\left[{ }^{3} \mathrm{H}\right] \mathrm{DOC}$, or $\left[{ }^{14} \mathrm{C}\right] \mathrm{DOC}$. After $4 \mathrm{~h}$ (MB164) or $24 \mathrm{~h}$ (SZ1) cultures were extracted with chloroform and dried under vacuum. The residues were dissolved in $10 \mu \mathrm{L}$ chloroform and spotted onto glass-backed silica-coated HPTLC plates (Kieselgel $60 \mathrm{~F}_{254}$, Merck; Darmstadt, Germany). In addition, small amounts of non-radioactive steroids were spotted as references. The HPTLC was developed twice in chloroform/methanol/water (300:20:1, v/v/v) and steroids identified after exposure to Fuji imaging plates and quantitated on a phosphoimager (BAS-2500, Fuji; Stamford, CT, USA).

\subsection{Computational Methods}

\subsubsection{Molecular Docking}

First molecular docking was performed for the compound $(R)-\mathbf{8 g}$ and $(S)-\mathbf{8 g}$ to assess their binding feasibility and difference. A six-step procedure was applied. (1) Three crystal structures of $C$. albicans CYP51 (PDB code: 5TZ1, 5FSA, 5V5Z) were taken from Pocketome [55], in which different PDB structures of the same protein were superimposed by the binding sites to take the induce-fit effect into consideration. (2) All structures were combined to calculate grid potential ensembles for the docking of $(R)-8 g$ and $(S)-8 g$. The grid maps were calculated on a $0.5 \AA$ 3D grid, containing: (i) van der Waals potentials; (ii) electrostatic potentials; (iii) hydrogen bonding potentials; and (iv) hydrophobic potential grids. (3) The structures of ligands were taken from crystallography [43]. (4) Four distinctive starting poses were generated for sampling. (5) The ligand was then sampled in the pre-generated grid potential ensembles through biased probability Monte Carlo sampling method [56] to optimize the positional variables of the ligand. (6) After the sampling, the ligand conformation was re-scored with the full-atom ICM scoring function [57]. All docking and scoring were performed in ICM-Pro v3.8-7c.

\subsubsection{Molecular Dynamics Simulation}

Molecular dynamics simulation was performed as previously described [21]. Briefly, docking studies were performed using MOE [40] and CaCYP51 (PDB 5FSA [39]) to generate pdb files of the CaCYP51 crystal structure complexed with $(R)-8 g$ and $(S)-8 g$. Molecular dynamics simulations were run on the CaCYP51-ligand complexes with the pdb files first optimized with protein preparation wizard in Maestro by assigning bond orders, adding hydrogen, and correcting incorrect bond types. A default quick relaxation protocol was used to minimise the MD systems with the Desmond program [41]. Force-field parameters for the complexes were assigned using the OPLS_ 2005 forcefield, that is, a 100 ns molecular dynamic run in the NPT ensemble $(T=300 \mathrm{~K})$ at a constant pressure of 1 bar. Energy and trajectory atomic coordinate data were recorded at each $1.2 \mathrm{~ns}$.

\section{Conclusions}

A series of 2-aryl-3-azolyl-1-indolyl-propan-2-ols was designed as new analogs of FLC by replacing one of its two triazole moieties by an indole scaffold. A first chemical approach was developed in seven steps, involving the synthesis of the key intermediate 1-(1H-benzotriazol-1-yl)methyl- $1 H$-indole 4 and the final opening of oxiranes 7 by imidazole or $1 H-1,2,4$-triazole. A shorter process was also developed to access the target compounds in only three steps, this time with the ring opening by indole and analogs. Twenty azole derivatives were synthesized and tested against C. albicans and other Candida species. Thirteen compounds demonstrated a high level of activity against C. albicans CA98001, with MIC $<0.027 \mu \mathrm{g} / \mathrm{mL}$, by comparison with the MIC value of FLC (MIC $=0.020 \mu \mathrm{g} / \mathrm{mL}$ ). The in vitro cytotoxicity of compounds $\mathbf{8 a}-\mathbf{g}$ and $\mathbf{1 1 a}-\mathbf{k}$ was further evaluated on MRC-5 cells.

The enantiomers of the best anti-Candida compound, 2-(2,4-dichlorophenyl)-3-(1H-indol-1-yl)-1(1H-1,2,4-triazol-1-yl)-propan-2-ol 8g, were analyzed by X-ray diffraction to determine their absolute 
configuration. The (-)-8g enantiomer (MIC $=0.000256 \mu \mathrm{g} / \mathrm{mL}$ against C. albicans CA98001) was found with the $S$-absolute configuration. Additionally, molecular docking and MD simulation were performed and confirmed that the $(S)$-enantiomer aligned with the positioning of posaconazole within both the heme and access channel binding sites. These in silico results are consistent with the biological results presented. The selectivity of compounds $\mathbf{1 1 d}, \mathbf{8 g}$, and its enantiomers was also investigated against five human P450-dependent enzymes (CYP19, CYP17, CYP26A1, CYP11B1, and CYP11B2).

Overall, (S)-8g had a pharmacological profile to pursue further biological investigations such as a murine candidiasis assay and cytochrome P450 inhibition assays (e.g. CYP3A4, CYP2D6). Recently, we published extended biological exploration of $\mathbf{8 g}$ (in vitro and in vivo assays) and then we confirmed the full potential of this molecule [28]. Another major challenge is the emergence of resistance to azole antifungals among Candida species [58]. Then a multi-disciplinary approach with joint expertise and networks is crucial to assist efficiently medicinal chemists for new optimizations. According to the 3D structures of CaCYP51 and our results obtained (Figure 9), further pharmacomodulation works should be performed to explore both the position of the azolyl chain on indole scaffold and the introduction of a long chain to occupy the space of the access channel (as does the $\mathrm{N}$-arylpiperazine chain of posaconazole). In this regard, NMR will be of special interest for studying ligand access channels in cytochrome P450 enzymes [59-62].

A further biological investigation could be performed by testing a selection of our best 2-aryl-3-azolyl-1-indolyl-propan-2-ols (e.g. 8d, 8f, (-)-(S)-8g, 11g, 11h, 11i) against the emerging Candida auris strain.

The last point is that the antifungal azoles targeting CaCYP51 could be a starting point for developing new treatments in some particular diseases such as human infections with protozoa (Trypanosomatidae) [63] and primary amoebic meningoencephalitis (PAM) [64]. The needs for new treatments are enormous in the field of parasitic diseases, and CYP51 is a promising target for further drug development.

Author Contributions: Conceptualization, P.L.P. and M.L.B.; methodology, Y.M.N., N.L., F.P., M.-P.L., P.P., S.W.Y., D.S., T.H., M.M., and J.G.; software, R.A.; validation, R.W.H., R.B., C.S., R.A., P.L.P., and M.L.B.; investigation, G.L.P., P.L.P., and M.L.B.; resources, P.L.P. and R.W.H.; data curation, A.M., P.L.P., and M.L.B.; writing-original draft preparation, N.L., F.P., M.-P.L., R.B., J.G., A.M., and C.S.; writing-review and editing, N.L., I.K., P.L.P. C.S., and M.L.B.; visualization, J.G., D.S., and R.A.; supervision, G.L.B., P.L.P., and M.L.B.; project administration, G.L.B., P.L.P., and M.L.B.; funding acquisition, G.L.B. All authors have read and agreed to the published version of the manuscript.

Funding: This research was financially supported by Yang Ji Chemical Company of South Korea.

Acknowledgments: A doctoral scholarship from the Research Association AGISMED to Y.-M. Na and N. Lebouvier are gratefully acknowledged. We are also grateful to Le Floch (Yanikem s.a.r.l.) for their continued support. A doctoral fellowship from the « Ministère de l'Enseignement Supérieur et de la Recherche » to M.-P. Lézé is gratefully acknowledged. Molecular dynamics simulations were undertaken using the supercomputing facilities at Cardiff University operated by Advanced Research Computing at Cardiff (ARCCA) on behalf of the Cardiff Supercomputing Facility and the HPC Wales and Supercomputing Wales (SCW) projects. We acknowledge the support of the latter, which is part-funded by the European Regional Development Fund (ERDF) via the Welsh Government.

Conflicts of Interest: The authors declare no conflict of interest.

\section{References}

1. Brown, G.D.; Denning, D.W.; Gow, N.A.R.; Levitz, S.M.; Netea, M.G.; White, T.C. Hidden killers: Human fungal infections. Sci. Transl. Med. 2012, 4, 165rv13. [CrossRef] [PubMed]

2. Pianalto, K.M.; Alspaugh, J.A. New horizons in antifungal therapy. J. Fungi 2016, 2, 26. [CrossRef] [PubMed]

3. Winthrop, K.L. Risk and prevention of tuberculosis and other serious opportunistic infections associated with the inhibition of tumor necrosis factor. Nat. Clin. Pract. Rheumatol. 2006, 2, 602-610. [CrossRef] [PubMed]

4. Laniado-Laborín, R.; Cabrales-Vargas, M.N. Amphotericin B: Side effects and toxicity. Rev. Iberoam Micol. 2009, 26, 223-227. [CrossRef] 
5. De Oliveira Santos, G.C.; Vasconcelos, C.C.; Lopes, A.J.O.; De Sousa Cartágenes, M.D.S.; Filho, A.K.D.B.; Do Nascimento, F.R.F.; Ramos, R.M.; Pires, E.R.R.B.; De Andrade, M.S.; Rocha, F.M.G.; et al. Candida infections and therapeutic strategies: Mechanisms of action for traditional and alternative agents. Front. Microbiol. 2018, 9, 1351. [CrossRef]

6. Autmizguine, J.; Smith, P.B.; Prather, K.; Bendel, C.; Natarajan, G.; Bidegain, M.; Kaufman, D.A.; Burchfield, D.J.; Ross, A.S.; Pandit, P.; et al. Effect of fluconazole prophylaxis on Candida fluconazole susceptibility in premature infants. J. Antimicrob. Chemother. 2018, 73, 3482-3487. [CrossRef]

7. Kaguelidou, F.; Pandolfini, C.; Manzoni, P.; Choonara, I.; Bonati, M.; Jacqz-Aigrain, E. European survey on the use of prophylactic fluconazole in neonatal intensive care units. Eur. J. Pediatr. 2012, 171, 439-445. [CrossRef]

8. Mishra, M.; Agrawal, S.; Raut, S.; Kurhade, A.M.; Powar, R.M. Profile of yeasts isolated from urinary tracts of catheterized patients. J. Clin. Diagn. Res. 2014, 8, 44-46. [CrossRef]

9. Chen, T.C.; Chen, Y.H.; Chen, Y.C.; Lu, P.L. Fluconazole exposure rather than clonal spreading is correlated with the emergence of Candida glabrata with cross-resistance to triazole antifungal agents. Kaohsiung J. Med. Sci. 2012, 28, 306-315. [CrossRef]

10. Campoy, S.; Adrio, J.L. Antifungals. Biochem. Pharmacol. 2017, 133, 86-96. [CrossRef]

11. Zambrano-Huerta, A.; Cifuentes-Castañeda, D.D.; Bautista-Renedo, J.; Mendieta-Zerón, H.; Melgar-Fernández, R.C.; Pavón-Romero, S.; Morales-Rodríguez, M.; Frontana-Uribe, B.A.; González-Rivas, N.; Cuevas-Yañez, E. Synthesis and in vitro biological evaluation of 1,3-bis-(1,2,3-triazol-1-yl)-propan-2-ol derivatives as antifungal compounds fluconazole analogues. Med. Chem. Res. 2019, 28, 571-579. [CrossRef]

12. Pongas, G.N.; Lewis, R.E.; Samonis, G.; Kontoyiannis, D.P. Voriconazole-associated Zygomycosis: A significant consequence of evolving antifungal prophylaxis and immunosuppression practices? Clin. Microbiol. Infect. 2009, 15, 93-97. [CrossRef] [PubMed]

13. Theuretzbacher, U. Pharmacokinetics/pharmacodynamics of Echinocandins. Eur. J. Clin. Microbiol. Infect. Dis. 2004, 23, 805-812. [CrossRef] [PubMed]

14. Rabelo, V.W.; Santos, T.F.; Terra, L.; Santana, M.V.; Castro, H.C.; Rodrigues, C.R.; Abreu, P.A. Targeting CYP51 for drug design by the contributions of molecular modeling. Fundam. Clin. Pharmacol. 2017, 31, 37-53. [CrossRef] [PubMed]

15. Lepesheva, G.I.; Waterman, M.R. Sterol 14 $\alpha$-demethylase cytochrome P450 (CYP51), a P450 in all biological kingdoms. Biochim. Biophys. Acta 2007, 1770, 467-477. [CrossRef]

16. Keniya, M.V.; Sabherwal, M.; Wilson, R.K.; Woods, M.A.; Sagatova, A.A.; Tyndall, J.D.A.; Monk, B.C. Crystal structures of full-length lanosterol $14 \alpha$-demethylases of prominent fungal pathogens Candida albicans and Candida glabrata provide tools for antifungal discovery. Antimicrob. Agents Chemother. 2018, 62. [CrossRef]

17. Onyewu, C.; Blankenship, J.R.; Del Poeta, M.; Heitman, J. Ergosterol biosynthesis inhibitors become fungicidal when combined with calcineurin inhibitors against Candida albicans, Candida glabrata, and Candida krusei. Antimicrob. Agents Chemother. 2003, 47, 956-964. [CrossRef]

18. Lézé, M.-P.; Le Borgne, M.; Pinson, P.; Palusczak, A.; Duflos, M.; Le Baut, G.; Hartmann, R.W. Synthesis and biological evaluation of 5-[(aryl)(1H-imidazol-1-yl)methyl $]-1 \mathrm{H}$-indoles: Potent and selective aromatase inhibitors. Bioorg. Med. Chem. Lett. 2006, 16, 1134-1137. [CrossRef]

19. Le Borgne, M.; Marchand, P.; Delevoye-Seiller, B.; Robert, J.M.; Le Baut, G.; Hartmann, R.W.; Palzer, M. New selective nonsteroidal aromatase inhibitors: Synthesis and inhibitory activity of 2, 3 or 5-(alpha-azolylbenzyl)-1H-indoles. Bioorg. Med. Chem. Lett. 1999, 9, 333-336. [CrossRef]

20. Martínez-Matías, N.; Rodríguez-Medina, J.R. Fundamental concepts of azole compounds and triazole antifungals: A beginner's review. P. R. Health Sci. J. 2018, 37, 135-142.

21. Binjubair, F.A.; Parker, J.E.; Warrilow, A.G.; Puri, K.; Braidley, P.J.; Tatar, E.; Kelly, S.L.; Kelly, D.E.; Simons, C. Small molecule inhibitors targeting sterol 14 $\alpha$-demethylase (CYP51): Synthesis, molecular modelling and evaluation against Candida albicans. ChemMedChem 2020, 15, 1-17. [CrossRef] [PubMed]

22. Na, Y.M.; Le Borgne, M.; Pagniez, F.; Le Baut, G.; Le Pape, P. Synthesis and antifungal activity of new 1-halogenobenzyl-3-imidazolylmethylindole derivatives. Eur. J. Med. Chem. 2003, 38, 75-87. [CrossRef]

23. Pagniez, F.; Le Borgne, M.; Marchand, P.; Na, Y.M.; Le Baut, G.; Robert-Piessard, S.; Le Pape, P. In vitro activity of a new antifungal azolyl-substituted indole against Aspergillus fumigatus. J. Enzyme Inhib. Med. Chem. 2002, 17, 425-429. [CrossRef] [PubMed] 
24. Guillon, R.; Giraud, F.; Logé, C.; Le Borgne, M.; Picot, C.; Pagniez, P.; Le Pape, P. Design of new antifungal agents: Synthesis and evaluation of 1-[(1H-indol-5-ylmethyl)amino]-2-phenyl-3-(1H-1,2,4-triazol-1-yl)propan-2-ols. Bioorg. Med. Chem. Lett. 2009, 19, 5833-5836. [CrossRef] [PubMed]

25. Lebouvier, N.; Pagniez, F.; Duflos, M.; Le Pape, P.; Na, Y.M.; Le Baut, G.; Le Borgne, M. Synthesis and antifungal activities of new fluconazole analogues with azaheterocycle moiety. Bioorg. Med. Chem. Lett. 2007, 17, 3686-3689. [CrossRef] [PubMed]

26. Pagniez, F.; Lebouvier, N.; Na, Y.M.; Le Borgne, M.; Pfalzer, M.; Hartmann, R.W.; Le Pape, P. Broad spectrum anti-Candida activities of a new indolyl-triazole, NL114. In Proceedings of the 17th European Congress of Clinical Microbiology and Infectious Diseases and 25th International Congress of Chemotherapy, Munich, Germany, 31 March-3 April 2007; Volume 29, p. 474.

27. Lebouvier, N.; Giraud, F.; Corbin, T.; Na, Y.M.; Le Baut, G.; Marchand, P.; Le Borgne, M. Efficient microwave-assisted synthesis of 1-(1H-indol-1-yl)-2-phenyl-3-(1H-1,2,4-triazol-1-yl)propan-2-ols as antifungal agents. Tetrahedron Lett. 2006, 47, 6479-6483. [CrossRef]

28. Pagniez, F.; Lebouvier, N.; Na, Y.M.; Ourliac-Garnier, I.; Picot, C.; Le Borgne, M.; Le Pape, P. Biological exploration of a novel 1,2,4-triazole-indole hybrid molecule as antifungal agent. J. Enzyme Inhib. Med. Chem. 2020, 35, 398-403. [CrossRef]

29. Hutschenreuter, T.U.; Ehmer, P.B.; Hartmann, R.W. Synthesis of hydroxy derivatives of highly potent non-steroidal CYP 17 inhibitors as potential metabolites and evaluation of their activity by a non cellular assay using recombinant human enzyme. J. Enzyme Inhib. Med. Chem. 2004, 19, 17-32. [CrossRef]

30. Kragie, L.; Turner, S.D.; Patten, C.J.; Crespi, C.L.; Stresser, D.M. Assessing pregnancy risks of azole antifungals using a high throughput aromatase inhibition assay. Endocr. Res. 2002, 28, 129-140. [CrossRef]

31. Trösken, E.R.; Fischer, K.; Völkel, W.; Lutz, W.K. Inhibition of human CYP19 by azoles used as antifungal agents and aromatase inhibitors, using a new LC-MS/MS method for the analysis of estradiol product formation. Toxicology 2006, 219, 33-40. [CrossRef]

32. Lézé, M.P.; Palusczak, A.; Hartmann, R.W.; Le Borgne, M. Synthesis of 6-or 4-functionalized indoles via a reductive cyclization approach and evaluation as aromatase inhibitors. Bioorg. Med. Chem. Lett. 2008, 18, 4713-4715. [CrossRef] [PubMed]

33. Le Borgne, M.; Marchand, P.; Nourrisson, M.R.; Loquet, D.; Palzer, M.; Le Baut, G.; Hartmann, R.W. Synthesis and biological evaluation of 3-(azolylmethyl)-1 H-indoles and 3-( $\alpha$-azolylbenzyl)- $1 H$-indoles as selective aromatase inhibitors. J. Enzyme Inhib. Med. Chem. 2007, 22, 667-676. [CrossRef] [PubMed]

34. Marchand, P.; Le Borgne, M.; Palzer, M.; Le Baut, G.; Hartmann, R.W. Preparation and pharmacological profile of 7-( $\alpha$-azolylbenzyl)-1H-indoles and indolines as new aromatase inhibitors. Bioorg. Med. Chem. Lett. 2003, 13, 1553-1555. [CrossRef]

35. Le Borgne, M.; Marchand, P.; Duflos, M.; Delevoye-Seiller, B.; Piessard-Robert, S.; Le Baut, G.; Hartmann, R.W.; Palzer, M. Synthesis and in vitro evaluation of 3-(1-azolylmethyl)-1H-indoles and 3-(1-azolyl-1-phenylmethyl)-1H-indoles as inhibitors of P450 arom. Arch. Pharm. 1997, 330, 141-145. [CrossRef] [PubMed]

36. Le Borgne, M.; Marchand, P.; Duflos, M.; Robert-Piessard, S.; Le Baut, G.; Ahmadi, M.; Hartmann, R.W.; Palzer, M. Comparison of the in-vitro aromatase inhibitory activity of 3-(azolylmethyl)-1H-indoles. Pharm. Pharmacol. Commun. 1997, 3, 279-281.

37. Denner, K.; Vogel, R.; Schmalix, W.; Doehmer, J.; Bernhardt, R. Cloning and stable expression of the human mitochondrial cytochrome P45011B1cDNA V79 Chinese harmster cells and their application for testing of potential inhibitors. Pharmacogenetics 1995, 5, 89-96. [CrossRef]

38. Hakki, T.; Hübel, K.; Waldmann, H.; Bernhardt, R. The development of a whole-cell based medium throughput screening system for the discovery of human aldosterone synthase (CYP11B2) inhibitors: Old drugs disclose new applications for the therapy of congestive heart failure, myocardial fibrosis and hypertension. J. Steroid Biochem. Mol. Biol. 2011, 125, 120-128. [CrossRef] 
39. Hargrove, T.Y.; Friggeri, L.; Wawrzak, Z.; Qi, A.; Hoekstra, W.J.; Schotzinger, R.J.; York, J.D.; Guengerich, F.P.; Lepesheva, G.I. Structural analyses of Candida albicans sterol 14 alpha-demethylase complexed with azole drugs address the molecular basis of azole-mediated inhibition of fungal sterol biosynthesis. J. Biol. Chem. 2017, 292, 6728-6743. [CrossRef]

40. Molecular Operating Environment (MOE); 2015.10; Chemical Computing Group Inc.: Montreal, QC, Canada, 2016.

41. Schrödinger Release 2020-1; Desmond Molecular Dynamics System, D.E. Shaw Research, New York, NY, 2020. Maestro-Desmond Interoperability Tools, Schrödinger, New York, NY, 2020. Available online: https://www.schrodinger.com/Desmond/ (accessed on 11 June 2020).

42. Burckhalter, J.H.; Stephens, V.C.; Hall, L.A.R. Proof of structures derived from the hydroxy- and amino-methylation of benzotriazole. J. Am. Chem. Soc. 1952, 74, 3868-3870. [CrossRef]

43. Katritzky, A.R.; Drewniak-Deyrup, M.; Lan, X.; Brunner, F. Preparation, lithiation and transformation of N-(benzotriazol-1-ylmethyl) heterocycles. J. Heterocycl. Chem. 1989, 26, 829-836. [CrossRef]

44. Crystallographic data (excluding structure factors) for the structure reported in this paper have been deposited with the Cambridge Crystallographic Data Centre as supplementary publication no. CCDC-237961 ((R)-8g) and no. CCDC-237960 ((S)-8g). Copies of the Data can be Obtained Free of Charge on Application to CCDC; University Chemical Lab.: 12 Union Road, Cambridge, UK, 2004.

45. North, A.C.T.; Phillips, D.C.; Mathews, F.S. A semi-empirical method of absorption correction. Acta Crystallogr. 1968, A24, 351-359. [CrossRef]

46. Sheldrick, G.M. SHELXS86. In Crystallographic Computing 3: Data Collection, Structure Determination, Proteins and Databases, 1st ed.; Sheldrick, G.M., Kröger, C., Goddard, R., Eds.; Oxford University Press: New-York, NY, USA, 1985; pp. 175-189.

47. Sheldrick, G.M. SHELXL-93. In A Program for the Refinement of the Crystal Structures from Diffraction Data; University of Göttingen: Göttingen, Germany, 1993.

48. Pagniez, F.; Le Pape, P. New fluorometric screening test for possible antifungal drugs. J. Mycol. Med. 2001, 11,73-78.

49. Thompson, E.A., Jr.; Siiteri, P.K. Utilization of oxygen and reduced nicotinamide adenine dinucleotide phosphate by human placental microsomes during aromatization of androstenedione. J. Biol. Chem. 1974, 249, 5364-5372. [PubMed]

50. Graves, P.E.; Salhanick, H.A. Stereoselective inhibition of aromatase by enantiomers of aminoglutethimide. Endocrinology 1979, 105, 52-57. [CrossRef] [PubMed]

51. Foster, A.B.; Jarman, M.; Leung, C.S.; Rowlands, M.G.; Taylor, G.N. Analogues of aminoglutethimide: Selective inhibition of cholesterol side-chain cleavage. J. Med. Chem. 1983, 26, 50-54. [CrossRef]

52. Ehmer, P.B.; Jose, J.; Hartmann, R.W. Development of a simple and rapid assay for the evaluation of inhibitors of human $17 \alpha$-hydroxylase-C $(17,20)$-lyase $(\mathrm{P} 450 \mathrm{c} 17)$ by coexpression of P450c17 with NADPH-cytochrome-P450-reductase in Escherichia coli. J. Steroid Biochem. Mol. Biol. 2000, 75, 57-63. [CrossRef]

53. Gomaa, M.S.; Bridgens, C.E.; Illingworth, N.A.; Veal, G.J.; Redfern, C.P.F.; Brancale, A.; Armstrong, J.L.; Simons, C. Novel retinoic acid 4-hydroxylase (CYP26) inhibitors based on a 3-(1H-imidazol- and triazol-1-yl)-2,2-dimethyl-3-(4-(phenylamino)phenyl)propyl scaffold. Bioorg. Med. Chem. 2012, 20, 4201-4207. [CrossRef]

54. Bureik, M.; Hübel, K.; Dragan, C.A.; Scher, J.; Becker, H.; Lenz, L.; Bernhardt, R. Development of test systems for the discovery of selective human aldosterone synthase (CYP11B2) and 11ß-hydroxylase (CYP11B1) inhibitors. Discovery of a new lead compound for the therapy of congesitve heart failure, myocardial fibrosis and hypertension. Mol. Cell. Endocrinol. 2004, 217, 249-254. [CrossRef]

55. Kufareva, I.; Ilatovskiy, A.V.; Abagyan, R. Pocketome: An encyclopedia of small-molecule binding sites in 4D. Nucleic Acids Res. 2012, 40, D535-D540. [CrossRef]

56. Abagyan, R.; Totrov, M. Biased probability Monte Carlo conformational searches and electrostatic calculations for peptides and proteins. J. Mol. Biol. 1994, 235, 983-1002. [CrossRef]

57. Neves, M.A.C.; Totrov, M.; Abagyan, R. Docking and scoring with ICM: The benchmarking results and strategies for improvement. J. Comput. Aided Mol. Des. 2012, 26, 675-686. [CrossRef] [PubMed]

58. Cavling Arendrup, M.; Patterson, T.F. Multidrug-resistant Candida: Epidemiology, molecular mechanisms, and treatment. J. Infect. Dis. 2017, 216, S445-S451. [CrossRef] [PubMed] 
59. Mak, P.J.; Denisov, I.G. Spectroscopic studies of the cytochrome P450 reaction mechanisms. Biochim. Biophys. Acta 2018, 1866, 178-204. [CrossRef] [PubMed]

60. Urban, P.; Lautier, T.; Pompon, D.; Truan, G. Ligand access channels in cytochrome P450 enzymes: A review. Int. J. Mol. Sci. 2018, 19, 1617. [CrossRef] [PubMed]

61. Basudhar, D.; Madrona, Y.; Kandel, S.; Lampe, J.N.; Nishida, C.R.; Ortiz de Montellano, P.R. Analysis of cytochrome P450 CYP119 ligand-dependent conformational dynamics by two-dimensional NMR and x-ray crystallography. J. Biol. Chem. 2015, 290, 10000-10017. [CrossRef] [PubMed]

62. Raingeval, C.; Cala, O.; Brion, B.; Le Borgne, M.; Hubbard, R.E.; Krimm, I. 1D NMR WaterLOGSY as an efficient method for fragment-based lead discovery. J. Enzyme Inhib. Med. Chem. 2019, 34, 1218-1225. [CrossRef]

63. Friggeri, L.; Hargrove, T.Y.; Rachakonda, G.; Blobaum, A.L.; Fisher, P.; Melo de Oliveira, G.; França da Silva, C.; De Nazaré, C.; Soeiro, M.; Nes, W.D.; et al. Sterol $14 \alpha$-demethylase structure-based optimization of drug candidates for human infections with the protozoan Trypanosomatidae. J. Med. Chem. 2018, 61, 10910-10921. [CrossRef]

64. Debnath, A.; Calvet, C.M.; Jennings, G.; Zhou, W.; Aksenov, A.; Luth, M.R.; Abagyan, R.; Nes, W.D.; McKerrow, J.H.; Podust, L.M. CYP51 is an essential drug target for the treatment of primary amoebic meningoencephalitis (PAM). PLoS Negl. Trop. Dis. 2017, 11, e0006104. [CrossRef]

(C) 2020 by the authors. Licensee MDPI, Basel, Switzerland. This article is an open access article distributed under the terms and conditions of the Creative Commons Attribution (CC BY) license (http://creativecommons.org/licenses/by/4.0/). 